\title{
Technical and Financial Feasibility of a Solar Dryer in Bhutan
}

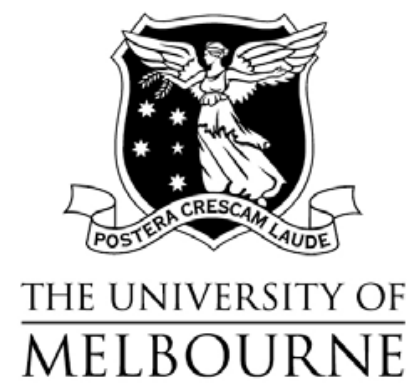

\author{
Tshewang Lhendup \\ Student No. 173513
}

\begin{abstract}
A report submitted for partial fulfillment of the requirements for the degree of Master of Engineering Science in Energy Studies
\end{abstract}

February 2005

\author{
International Technologies Centre (IDTC) \\ Department of Civil and Environmental Engineering \\ Faculty of Engineering
}




\section{ABSTRACT}

The technical and financial performance of an existing solar crop dryer at Khao-kor, Thailand has been evaluated for possible replication in Bhutan. The complete dryer system has been modelled using TRNSYS and the collector area was optimised to give minimum drying cost. From the evaluation, the average collector, pick-up and system efficiencies were found as 44\%, 23\% and 18\% respectively. The solar contribution to the load is 33\% when the dryer is used for 304 days in a year. Chilli and beef were selected as products to be dried as they are an integral part of Bhutan's dishes. The drying cost is US \$ 7.94 and 5.96 per $\mathrm{kg}$ of dry matter for chilli and beef respectively using the solar dryer system. The corresponding costs using an electric heating system is US \$ 7.76 and 6.25 per $\mathrm{kg}$ of dry matter for chilli and beef respectively. The solar dryer system was found to be cheaper compared to an electric heating system, however, from the commercial point of view, without any incentives, both the systems are financially non-viable in Bhutan. Nevertheless, the solar dryer system is more attractive than the electric heating system as its NPV at 13\% real discount rate is higher. 


\section{DECLARATION}

To the best of my knowledge and belief, this report neither contains material which has been accepted for the award of any other degree in any university nor any material previously published or written by another person, except where due reference is made in text. The length of this report exclusive of tables, figures, references and appendices is approximately 15000 words.

January 2005

Tshewang Lhendup 


\section{ACKNOWLEDGEMENT}

I profusely thank my two supervisors Dr. Bob Fuller and Dr. Lu Aye of International Technologies Centre (IDTC), the University of Melbourne for their invaluable help and guidance. I express deep sense of gratitude for their immense support and advice rendered at every stage of this research project.

I also wish to thank Mrs. Dechen Wangmo, Assistant Agriculture Extension Officer, Balhujora geog, Chhukha district, Bhutan for her help in collecting the necessary data.

Lastly, I thank AusAID for providing scholarship to study at the University of Melbourne. 


\section{ACRONYMS}

\begin{tabular}{|c|c|c|c|c|c|}
\hline AIT & : & Asian Institute of Technology & $\mathrm{kW}$ & : & Kilo Watt \\
\hline AVG & : & Average Day Model & $\mathrm{kWh}$ & $:$ & Kilo Watt hour \\
\hline BCR & & Benefit-Cost Ratio & LTD & : & Long-term data \\
\hline $\mathrm{BPC}$ & : & Bhutan Power Corporation & $\mathrm{m}$ & $:$ & Metre \\
\hline BSR & & Bhutan Schedule of Rates & $\mathrm{mm}$ & $:$ & Millimetre \\
\hline CGI & : & Corrugated iron & MoA & : & Ministry of Agriculture \\
\hline $\mathrm{COM}$ & & Compressed Weather Generation & MJ & : & Mega Joules \\
\hline $\mathrm{cm}$ & : & Centimetre & MWh & $:$ & Mega Watt hour \\
\hline $\mathrm{CSO}$ & : & $\begin{array}{l}\text { Central Statistical Organisation of } \\
\text { Bhutan }\end{array}$ & $\mathrm{N}$ & $:$ & North \\
\hline $\mathrm{db}$ & : & Dry basis & NASA & : & $\begin{array}{l}\text { National Aeronautics and Space } \\
\text { Administration }\end{array}$ \\
\hline EIU & : & Economist Intelligence Unit & NPV & : & Net Present Value \\
\hline EMC & : & Equilibrium Moisture Content & $\mathrm{Nu}$ & $:$ & $\begin{array}{l}\text { Ngultrum (Bhutan's local currency, } \\
\text { US } \$ 1 \cong \mathrm{Nu} 45 \text { ) }\end{array}$ \\
\hline FAO & : & Food and Agriculture Organisation & PCS & : & $\begin{array}{l}\text { Planning Commission Secretariat of } \\
\text { Bhutan }\end{array}$ \\
\hline GDP & : & Gross Domestic Product & $\mathrm{pJ}$ & $:$ & Peta Joules \\
\hline GEN & : & Hourly Weather Generator & RMA & $:$ & Royal Monetary Authority of Bhutan \\
\hline GI & : & Galvanised iron & RMS & $:$ & Root Mean Square \\
\hline GJ & : & Giga Joules & RMSD & $:$ & Root Mean Square Deviation \\
\hline gm & : & Gram & $\mathrm{s}$ & $:$ & Second \\
\hline $\mathrm{Hz}$ & : & Hertz & S & $:$ & South \\
\hline ITDG & : & $\begin{array}{l}\text { Intermediate Technology Development } \\
\text { Group }\end{array}$ & SQCD & : & $\begin{array}{l}\text { Standard and Quality Control } \\
\text { Division of Bhutan }\end{array}$ \\
\hline IEA & : & International Energy Agency & TMY & $:$ & Typical Meteorological Year \\
\hline IRR & : & Internal Rate of Return & TRY & $:$ & Test Reference Year \\
\hline $\mathrm{kg}$ & : & Kilogram & USDA & : & $\begin{array}{l}\text { United States Department of } \\
\text { Agriculture }\end{array}$ \\
\hline $\mathrm{kJ}$ & & Kilo Joules & V & $:$ & Voltage \\
\hline & & & wb & : & Wet basis \\
\hline
\end{tabular}




\section{CONTENTS}

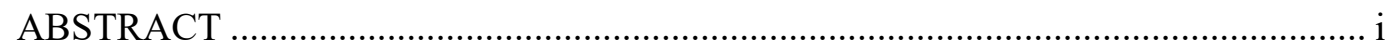

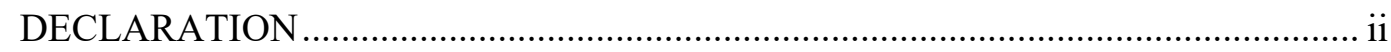

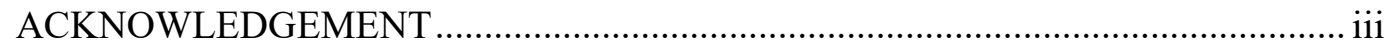

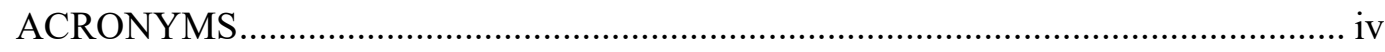

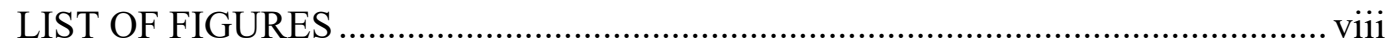

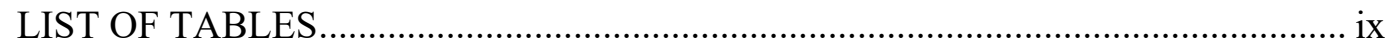

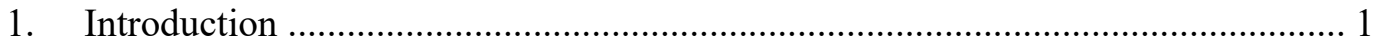

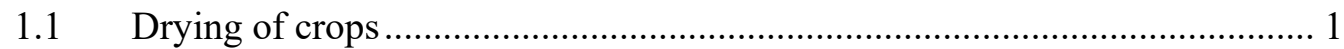

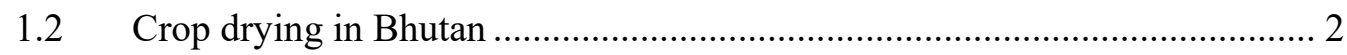

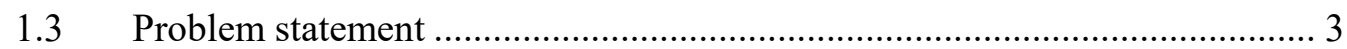

1.4 Aim, objectives and scope of work ....................................................... 5

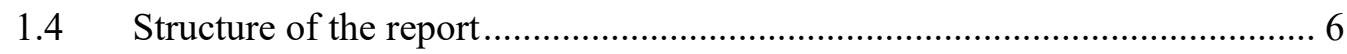

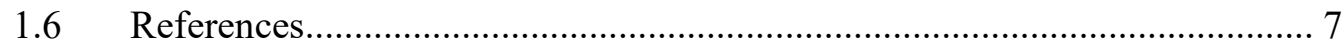

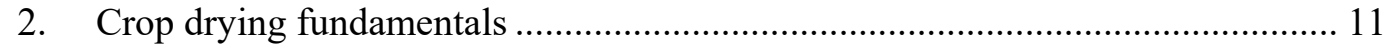

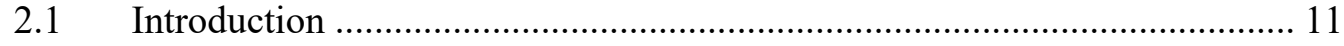

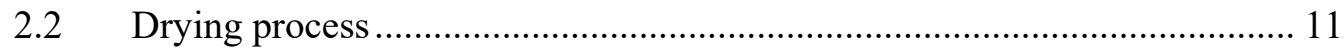

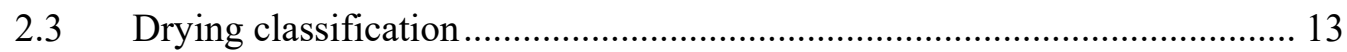

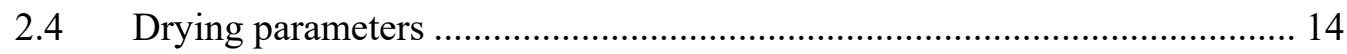

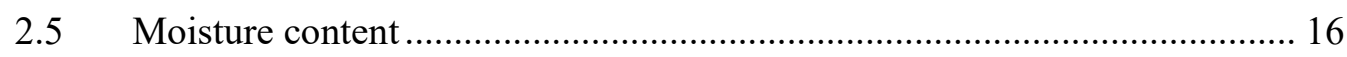

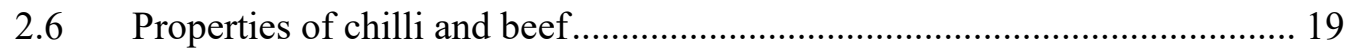

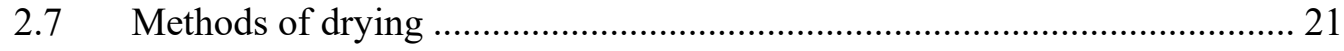

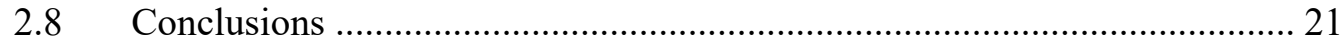

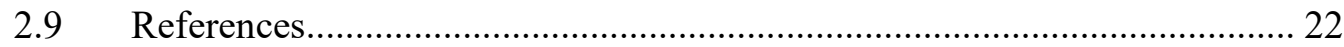

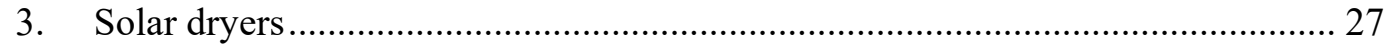

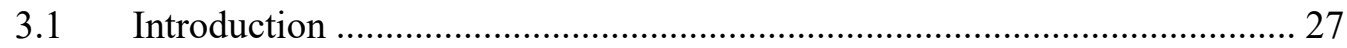

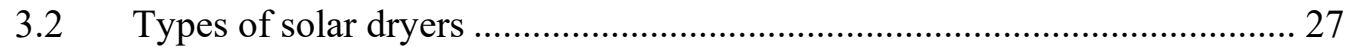

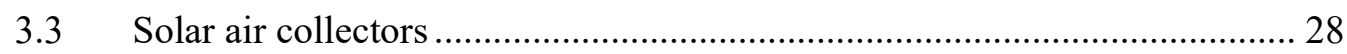

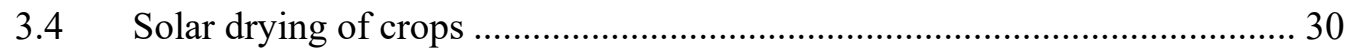




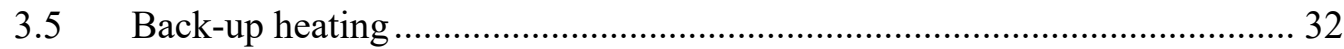

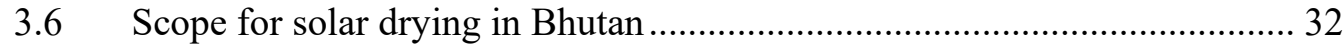

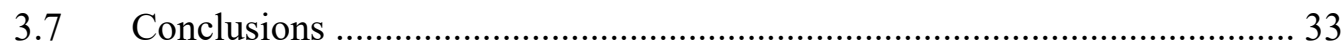

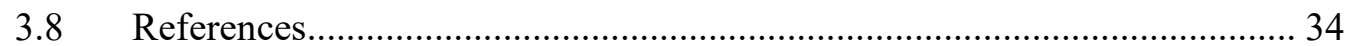

4. Generation of TMY data for Bhutan ............................................................ 40

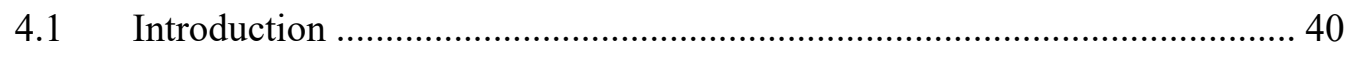

4.2 Methods of TMY data generation ....................................................... 41

$4.3 \quad$ Validation of Type 54 weather generator .............................................. 42

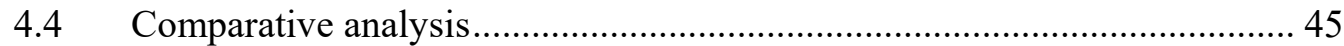

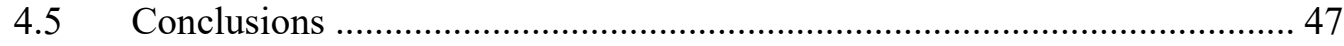

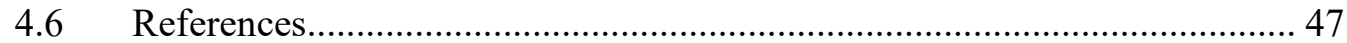

5. Performance evaluation of the existing solar dryer at Khao-kor ......................... 50

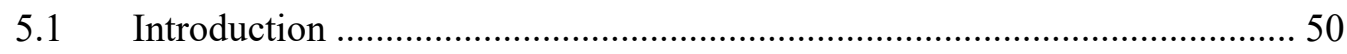

5.2 Performance evaluation by simulation ................................................ 51

5.3 Parameters of performance evaluation ................................................. 52

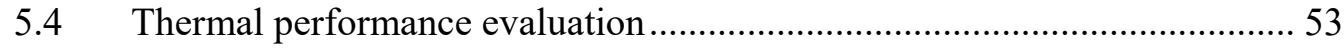

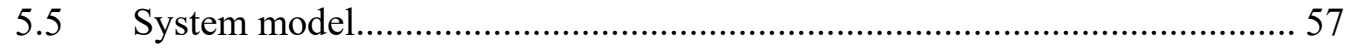

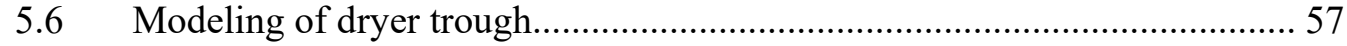

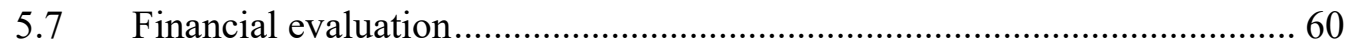

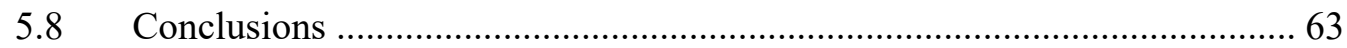

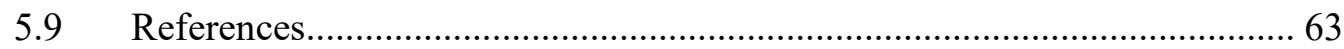

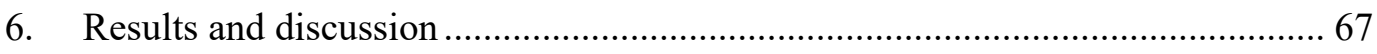

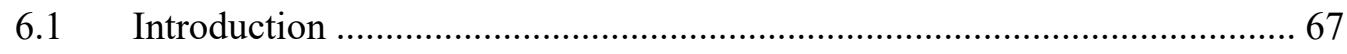

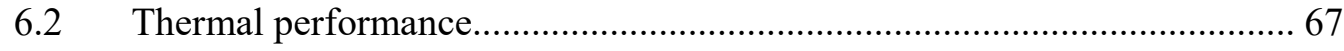

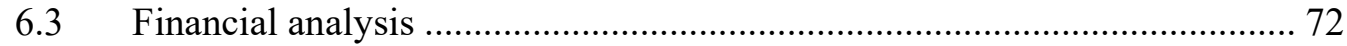

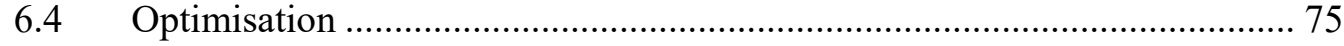

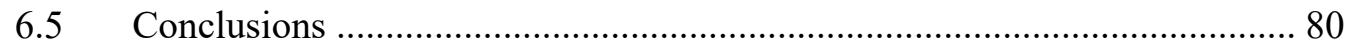

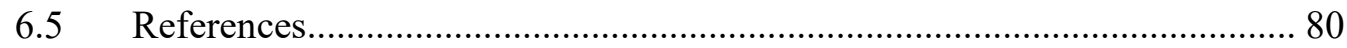

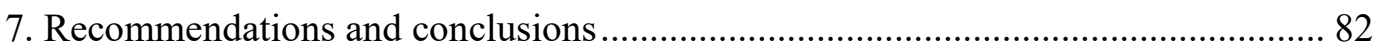

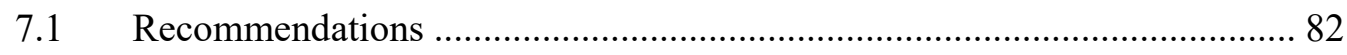

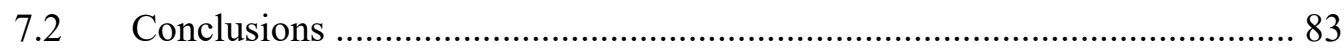

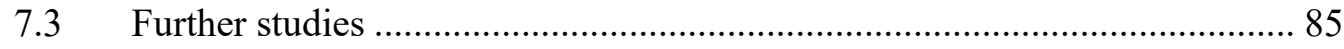




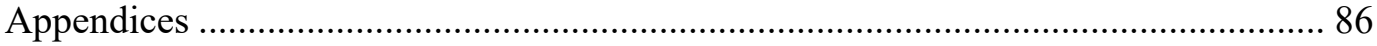

Appendix 1: Country background .................................................................... 86

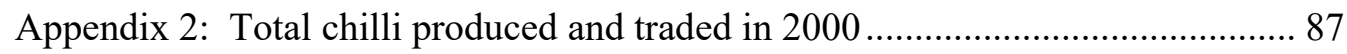

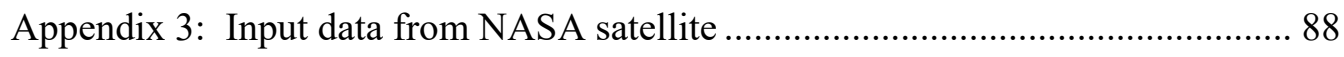

Appendix 4: Input data from long-term observed data........................................ 88

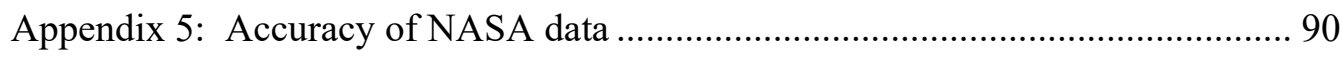

Appendix 6: Solar dryer performance evaluation parameters in the literature......... 91

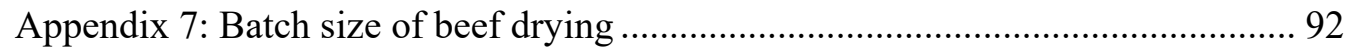

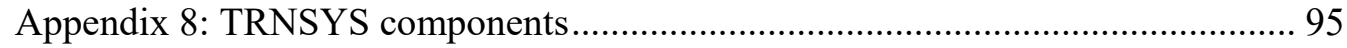

Appendix 9: Source code for Type 104 TRNSYS component................................. 98

Appendix 10: Estimation of real discount rate .................................................... 101

Appendix 11: Detailed cost estimate of the solar dryer system .......................... 103

Appendix 12: Exchange rate, US Dollar to Ngultrum.......................................... 105

Appendix 13: Cost-benefit analysis of chilli only …......................................... 106

Appendix 14: Cost-benefit analysis of chilli \& beef combined ............................ 107

Appendix 15: Optimisation of collector area....................................................... 108

Appendix 16: Cost-benefit analysis of optimised system.................................... 109

APPENDIX 17: Source code of Type 104 TRNSYS component in CD ............... 110

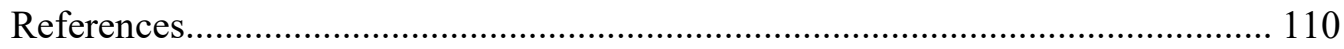




\section{LIST OF FIGURES}

Fig. 1.1. Map of Bhutan (1-5 shows main chilli growing districts) ............................. 3

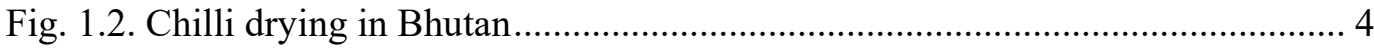

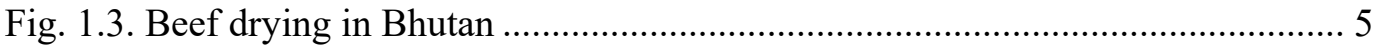

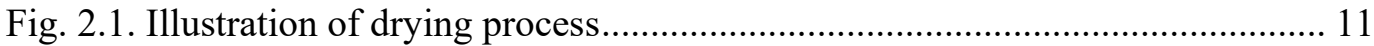

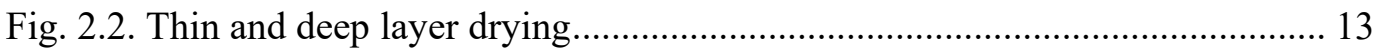

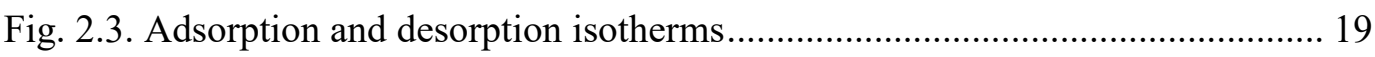

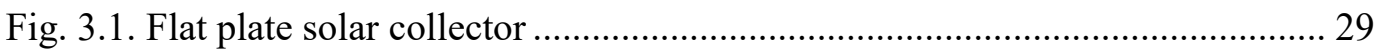

Fig. 4.1. Flowchart for validating Type 54 weather generator .................................. 43

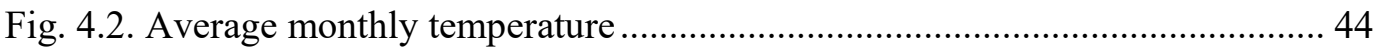

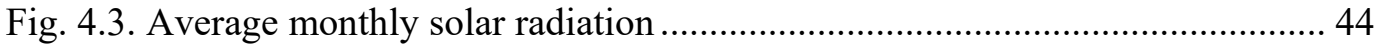

Fig. 4.4. Comparison of average daily horizontal surface radiation generated using NASA and AMLTO with TMY (a) Canberra (b) Hobart (c) Melbourne............. 46

Fig. 5.1. Comparison of radiation and ambient temperature in Bhutan and Khao-kor

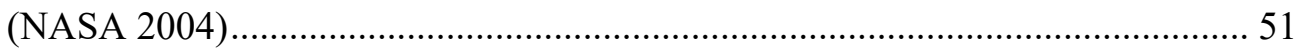

Fig. 5.2. Schematic diagram of solar dryer at Khao-kor .......................................... 54

Fig. 5.3. Average hourly solar radiation during the period August to September........ 55

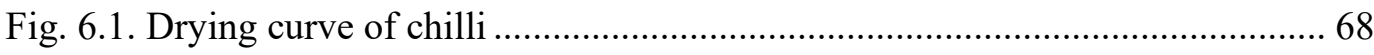

Fig. 6.2. Daily solar fraction during the period August to September..........................69 69

Fig. 6.3. Daily solar fraction during the periods $1^{\text {st }}$ January to $14^{\text {th }}$ of Feb, $16^{\text {th }}$ March to $14^{\text {th }}$ May, $16^{\text {th }}$ June to $31^{\text {st }}$ July and from October to December.................... 71

Fig. 6.4. Plot of annual cost and solar collector area............................................... 77 


\section{LIST OF TABLES}

Table 2.1. Recommended temperature for drying ................................................... 15

Table 2.2. Moisture absorption capacity ( $\mathrm{gm}$ of water $/ \mathrm{m}^{3}$ of air) ............................. 16

Table 2.3. Equilibrium moisture content ................................................................. 18

Table 2.4: Parameters of chilli used in this study .................................................... 20

Table 4.1: Yearly root-mean-square deviation of solar radiation............................... 45

Table 5.1. Parameters of existing dryer at Khao-kor................................................. 53

Table 6.1. Thermal performance of Khao-kor type solar dryer in Bhutan .................. 72

Table 6.2: Cost estimate of solar dryer system.......................................................... 73

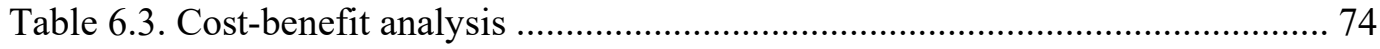

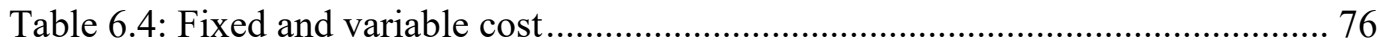

Table 6.5: Thermal performance of optimised system …........................................... 78

Table 6.6: Cost-benefit analysis of optimised system ............................................... 78

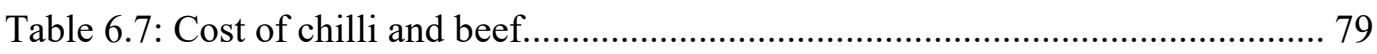




\section{INTRODUCTION}

\subsection{Drying of crops}

The seasonal characteristic of crops makes preservation necessary to assure a regular and continuous supply to the consumers through the year. Drying is one of the oldest and most practical methods of food preservation. Sun drying of agricultural produce has been practiced as a preservation technique in various parts of the world (Desrosier 1970; Ekechukwu \& Norton 1999; Esper \& Muhlbauer 1998; Farkas \& Smith 1987; Gallali et al. 2000; Gupta et al. 2002; ITDG 2004; Jayaraman \& Das Gupta 1987; Kaensup et al. 2002; Lutz et al. 1987; Pangavhane \& Sawhney 2002; Sarkar \& Saleh 2002; Sharma et al. 1986).

Most developing countries use the traditional sun drying method of spreading the agricultural produce on flat open ground with the produce directly exposed to the sun. The traditional sun drying method is associated with drawbacks like the requirement of large spaces and a long drying time, contamination of crops from foreign materials, crops subjected to insect infestation and crops being susceptible to re-absorption of moisture (Bassey 1981; Clark 1981; Ekechukwu \& Norton 1999; El-Sebaii et al. 2002; Exell \& Kornsakoo 1978; Fuller 1998; Lutz et al. 1987; Madhlopa et al. 2002; Maroulis \& Saravacos 1986; Sarkar \& Saleh 2002; Tiris et al. 1995; Vlachos et al. 2002). Moreover, traditional sun drying does not produce uniform quality (Keddie 1981). Also the traditional sun drying method is weather dependent and there is no shelter to protect the agricultural produce in the event of rain. As a result new drying methods are being implemented.

Most of the commercial crop dryers use fossil fuel. Wood and conventional fossil fuels are being used extensively for crop drying in most countries. Apart from this, expensive fuels like diesel and propane are also being used for crop drying (IEA 2003). Because of the increase in fuel consumption with a subsequent increase in price of conventional fossil fuels, solar dryers are being studied widely to substitute for the conventional method of crop drying (Pangavhane \& Sawhney 2002). Solar dryers are an appropriate preservation technology for a sustainable world and are being used in 
both developed and developing countries. A study done by IEA in 1999 estimated that solar drying of crops could save 657 to $1530 \mathrm{PJ}$ of energy annually (IEA 2003). This is more applicable but not limited to crops that are dried at temperature less than $60^{\circ} \mathrm{C}$. For crops that are dried at temperatures higher than $60^{\circ} \mathrm{C}$, solar drying could be used as a supplemental system.

\subsection{Crop drying in Bhutan}

Agriculture forms the backbone of the Bhutan's economy contributing 32.4\% of estimated GDP in 2002 (CSO 2003; EIU 2004) (see Appendix 1 for short introduction on Bhutan). Chilli is the most important spice crop, for both sale and consumption. In Bhutan, both green (fresh) and dried chilli is consumed like other vegetables and commonly known as a vegetable rather than as a spice (Berke 2002; Wissink 2004). Also chilli is not only an important part of family diets but one of the main cash crops. It is reported that farmers of the main chilli growing regions earn US \$ 555 to US \$ 667 per annum from the sale of chilli (Wangchuk 2004). In 2000, nearly 3000 tones of chilli were produced and about 1000 tonnes were traded (MoA 2000) (see Appendix 2 for details). The common species is Capsicum annum L which is large, fleshy and mild (Luitel 2004).

Among other vegetables, chilli has captured the Bhutanese market both in the rural community and the urban areas. Depending upon location and climate, chilli is grown in different seasons. Although chilli is grown all over Bhutan, major production is concentrated in the districts of Paro, Punakha and Wangdue in the west and Trashiyangtse and Trashigang in the east (MoA 2000). Fig.1.1 shows the chilli growing regions in Bhutan. However, regions in higher altitudes grow chilli from the months of April-May and harvest in the months of August-September while in lower regions it is grown in Feb-March and harvested in the months of April-May. While the lower regions do not face any problem in marketing chilli, the upper region faces a problem of marketing as chilli is harvested in the months of August-September when it is harvested all over Bhutan. The problem is further compounded by the rainy season which falls at the same time as the chilli harvesting time (Luitel 2004). 


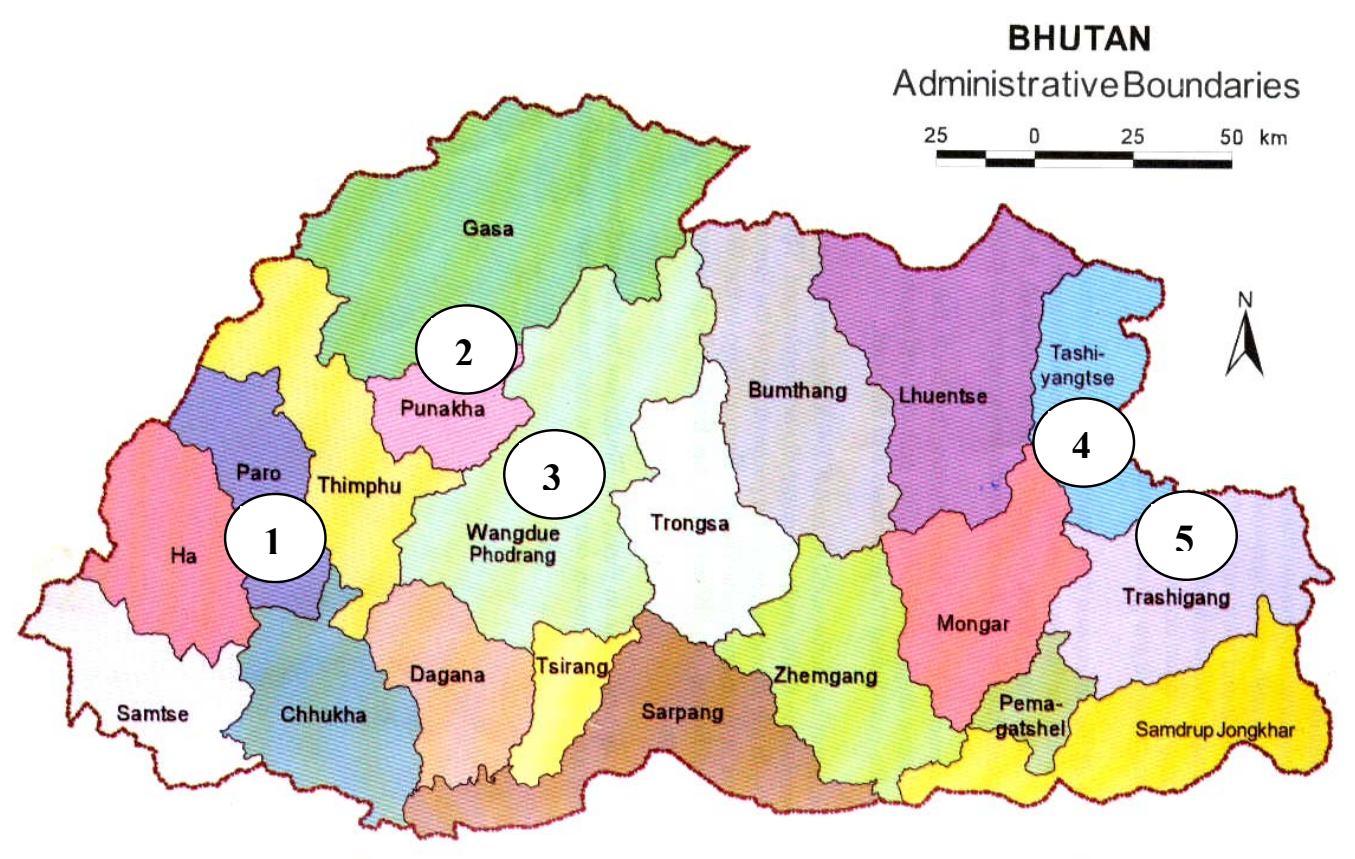

Fig. 1.1. Map of Bhutan (1-5 shows main chilli growing districts)

Similarly, meat also forms an indispensable part of the Bhutanese cuisine. Although, both fresh and dried meats are consumed like vegetables, Bhutanese prefer dried meat to fresh meat. In 2002, residents of Bhutan's capital Thimphu consumed 1438 tonnes of meat valued at US \$ 3 million, of which 665 tonnes was beef valued at US \$ one million (Dorji 2004). The rest was pork, chicken, mutton and fish. However, due to religious sentiments, slaughtering of animals is limited, so a substantial quantity of meat has to be imported from India (Wissink 2004).

\subsection{Problem statement}

As the chilli harvest season coincides with the monsoon, it is not always possible to dry chilli. Thus, it has become a common feature in Bhutan to see chilli flooding the local market for a relatively short period and then disappearing until the next season. This leads to very low financial incentives for farmers. This may be reduced if chilli could be dried when it is available abundantly. The dried product can be sold during 
the off-season to earn more. Although, chilli is being dried by the farmers, the method used for drying is very crude.

Fig. 1.2 illustrates the present chilli drying method in Bhutan. Chilli is dried on open ground with no shelter. It is common to see roof tops covered with chilli during the summer months. This results in poor quality associated with huge financial loss to the poor farmers. Chilli is also being dried by tying in strings and hanging on the walls. At present, no study has been done to estimate the loss of chilli from drying in this way and no alternative options have been investigated to improve the drying technique. Thus, it is envisaged that improvement in drying techniques may result in a better quality of dried chilli and fetch better prices for the farmers.

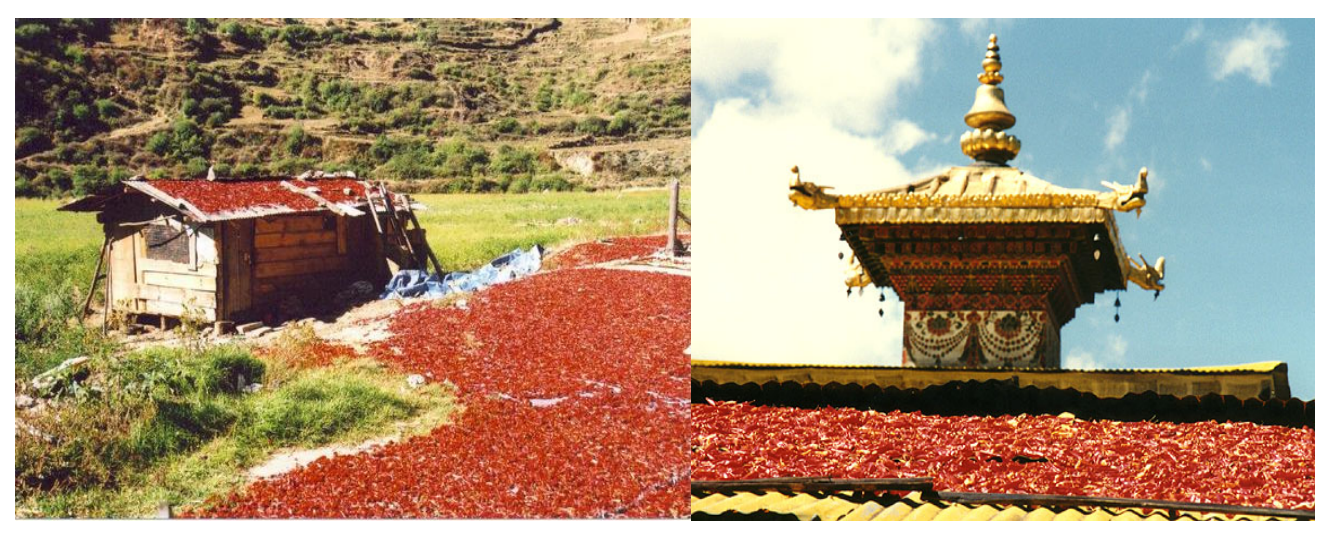

Fig. 1.2. Chilli drying in Bhutan

Likewise, the beef drying method is also very crude. Fig. 1.3 shows the beef drying method in Bhutan. The beef is subjected to insect infestation as well as being exposed to rain. It is very common to see every household drying beef in the open air. The quality of dried beef is very poor, resulting in loss of beef. An improved way of drying may result in better quality and minimise losses.

Considering the importance of chilli and meat in Bhutan and need to dry them when they are available abundantly, there is a need to study improved drying systems which are reliable and affordable to the farmers of Bhutan. However, Bhutan, situated in the Himalayas has no proven deposits of crude oil and natural gas (PCS 1997, 2002), so use of conventional drying systems would be too expensive for the Bhutanese farmers. 
Thus, an alternative approach, as suggested by the literature, is to use solar crop dryers. This technique has been used in both developed and developing countries with some success.

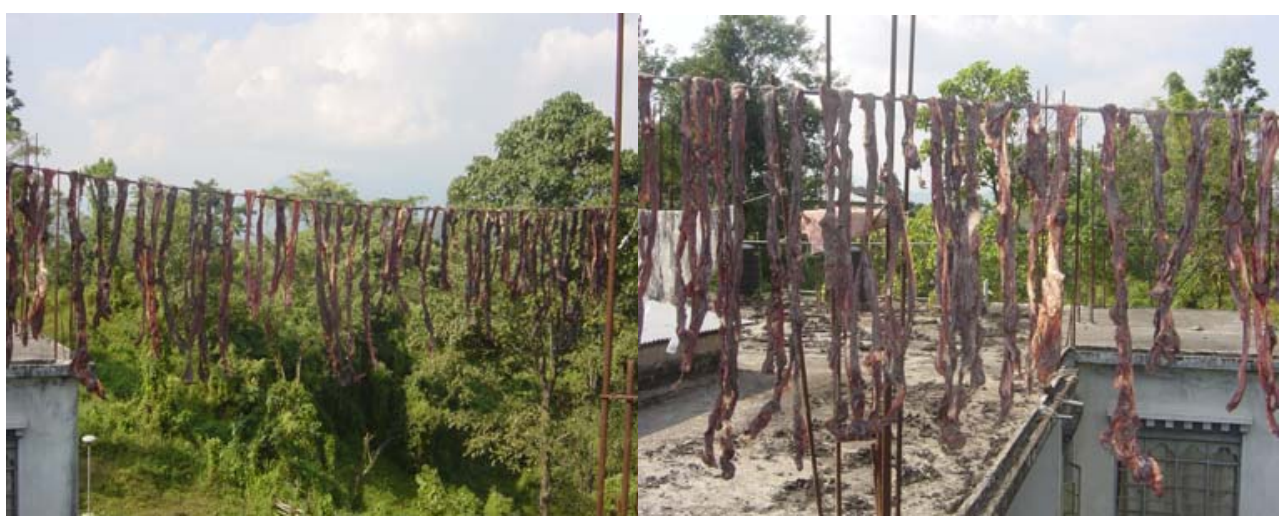

Fig. 1.3. Beef drying in Bhutan

Therefore, this study focuses on performance evaluation of an existing solar dryer in Thailand for possible replication in Bhutan. The principle product for investigation is chilli and beef is a supplemental product to be dried. The mode of study will be based on simulation, using a simulation software TRNSYS and determining the design parameters and performance of the dryer.

\subsection{Aim, objectives and scope of work}

\subsubsection{Aim}

The aim of this study is to evaluate the performance of an existing solar dryer system at Khao-kor in Thailand for possible adaptation in Bhutan.

\subsubsection{Objectives}

The objectives of this study are:

- To investigate present system of chilli and beef drying in Bhutan

- To generate a Typical Meteorological Year data file for Bhutan 
- Evaluate the existing Khao-kor solar dryer system with respect to technical performance and financial viability in Bhutan

- Propose an appropriate model and design parameters for a solar dryer for Bhutan

- Estimate financial benefits from the solar drying system

\subsubsection{Scope of work}

The study is limited to the following:

- The performance evaluation is limited to drying of chilli; and beef is investigated as a supplemental product to be dried when there are no chillies to dry.

- Study was done for Paro region of Bhutan and thus performance may vary for other regions.

- Financial feasibility is true only for Paro, and for other regions, the results may vary.

- The study was based on the TMY data generated using Type 54 weather generator with inputs obtained from NASA satellite which has a RMS bias of up to $\pm 17 \%$ and thus the results may vary from practical investigations.

\subsection{Structure of the report}

The report comprises seven sections. Section One is the introduction; the second and third sections present a review of drying principles and solar dryers with an emphasis on chilli and meat dryers. The fourth section describes the generation of the TMY data for Bhutan. The fifth and sixth sections present the evaluation of the technical and financial performance of the existing dryer in Thailand and the necessary modification required for possible replication in Bhutan. The last section presents the conclusions and recommendations on the performance evaluation. The last section also looks at the areas that require further analysis. 


\subsection{References}

Bassey, MW 1981, 'Solar Energy as a Heat Source in Crop Drying in Sierra Leone', paper presented to Food Drying, Edmonton, Alberta, Canada, 6-9 July 1981.

Berke, T 2002, 'The Asian Vegetable Research and Development Centre Pepper Project', paper presented to Sixteenth International Pepper Conference, Tampico, Tamaulipas, Mexico, 10 - 12 November 2002.

Clark, CS 1981, 'Solar Food Drying: A Rural Industry', Renewable Energy Review Journal, vol. 3, no. 1, pp. 23 - 36.

CSO 2003, Statistical Yearbook of Bhutan, The Planning Commission Secretariat, Royal Government of Bhutan, Thimphu, Bhutan.

Desrosier, NW 1970, The Technology of Food Preservation, 3 edn, The Avi Publishing Company, Westport, Connecticut, United States of America.

Dorji, T 2004, 'Nu 135.5 million spent on meat in 2002', Kuenselonline, Bhutan's daily news site, 30 May 2004.

EIU 2004, Country Report : Bhutan, The Economist Intelligence Unit, London, United Kingdom.

Ekechukwu, OV and Norton, B 1999, 'Review of solar-energy drying systems II: an overview of solar drying technology', Energy Conversion and Management, vol. 40, no. 6, pp. 615-55.

El-Sebaii, AA, Aboul-Enein, S, Ramadan, MRI and El-Gohary, HG 2002, 'Experimental investigation of an indirect type natural convection solar dryer', Energy Conversion and Management, vol. 43, no. 16, pp. 2251-66. 
Esper, A and Muhlbauer, W 1998, 'Solar drying - an effective means of food preservation', Renewable Energy, vol. 15, no. 1-4, pp. 95-100.

Exell, RHB and Kornsakoo, S 1978, 'A Low-Cost Solar Rice Dryer', Appropriate Technology, vol. 5, no. 1, pp. 23-4.

Farkas, I and Smith, CC 1987, 'Computer Simulation and Control of a Solar Crop Dryer', paper presented to European Cooperative Networks on Rural Energy Technical Meeting, Stutgart, Federal Republic of Germany, 9 - 11 September 1987.

Fuller, B 1998, Harnessing the Sun: Solar drying your own produce, Bolwarrah Press, Bolwarrah, Victoria, Australia.

Gallali, YM, Abujnah, YS and Bannani, FK 2000, 'Preservation of fruits and vegetables using solar drier: a comparative study of natural and solar drying, III; chemical analysis and sensory evaluation data of the dried samples (grapes, figs, tomatoes and onions)', Renewable Energy, vol. 19, no. 1-2, pp. 203-12.

Gupta, P, Ahmed, J, Shivare, US and Raghavan, GSV 2002, 'Drying Characteristics of Red Chilli', Drying Technology, vol. 20, no. 10, pp. 1975-87.

ITDG 2004, Solar Drying, Intermediate Technology Development Group, viewed 27 August 2004, $<$ http://www.itdg.org/html/technical_enquiries/docs/solar_drying.pdf $>$.

IEA 2003, Success stories of the IEA solar heating and Cooling Programme, viewed 15 July 2004, <http://www.iea-shc.org/welcome/shc_success_stories.pdf $>$.

Jayaraman, KS and Das Gupta, DK 1987, 'Drying of Fruits and Vegetables', in AS Mujumdar (ed.), Handbook of Industrial Drying, Marcel Dekker, Inc., New York, USA, p. 948. 
Kaensup, W, Chutima, S and Wongwises, S 2002, 'Experimental Study on Drying of Chilli in a Combined Microwave-Vacuum-Rotary Drum Dryer', Drying Technology, vol. 20, no. 10, pp. 2067-79.

Keddie, J (ed.) 1981, Technological choice and employment in food processing and storage and related policy issues, Appropriate Industrial Technology for Food Storage and Processing, United Nations Industrial Development Organisation, Vienna, Austria.

Luitel, PS 2004, 'Yield and management practice of chilli: a case study in Punakha, Bhutan (unpublished)', Master in Horticulture thesis, The University of Melbourne, Australia.

Lutz, K, Muhlbauer, W, Muller, J and Reisinger, J 1987, 'Development of a MultiPurpose Solar Crop Dryer for Arid Zones', paper presented to European Cooperative Networks on Rural Energy Technical Meeting, Stutgart, Federal Republic of Germany, 9 - 11 September 1987.

Madhlopa, A, Jones, SA and Kalenga Saka, JD 2002, 'A solar air heater with composite-absorber systems for food dehydration', Renewable Energy, vol. 27, no. 1, pp. 27-37.

Maroulis, ZB and Saravacos, GD 1986, 'Solar heating of air for drying agricultural products', Solar \& Wind Technology, vol. 3, no. 2, pp. 127-34.

MoA 2000, Renewable Natural Resources Statistics 2000, Ministry of Agriculture, Thimphu, Bhutan.

Pangavhane, DR and Sawhney, RL 2002, 'Review of research and development work on solar dryers for grape drying', Energy Conversion and Management, vol. 43, no. 1, pp. $45-61$. 
PCS 1997, Eighth five-year plan, The Planning Commission Secretariat, viewed 2 August 2004, <http://www.pcs.gov.bt/fyp/08/index.htm>.

PCS 2002, Ninth five-year plan, The Planning Commission Secretariat, viewed 5 August 2004, <http://www.pcs.gov.bt/fyp/09/index.htm>.

Sarkar, MAR and Saleh, T 2002, 'Performance study of a PV operated Forced Convection Solar Energy Dryer', paper presented to Eighth International Symposium for Renewable Energy Education (ISREE-8), Orlando, University of Florida, USA, 14 August 2002.

Sharma, VK, Sharma, S, Ray, RA and Garg, HP 1986, 'Design and performance studies of a solar dryer suitable for rural applications', Energy Conversion and Management, vol. 26, no. 1, pp. 111-9.

Tiris, C, Ozbalta, N, Tiris, M and Dincer, I 1995, 'Thermal performance of a new solar air heater', International Communications in Heat and Mass Transfer, vol. 22, no. 3, pp. 411-23.

Vlachos, NA, Karapantsios, TD, Balouktsis, AI and Chassapis, D 2002, 'Design and Testing of a New Solar Tray Dryer', Drying Technology, vol. 20, no. 6, pp. 124371.

Wangchuk, R 2004, 'The first chilli harvest in Bhutan', Kuenselonline, Bhutan's daily news site, 12 April 2004.

Wissink, T 2004, 'The Impact of Trade Liberalisation on Agriculture in Bhutan', paper presented to Eighteenth European Conference on Modern South Asian Studies, Lund, Sweden, 6 - 9 July 2004. 


\section{CROP DRYING FUNDAMENTALS}

\subsection{Introduction}

Most agricultural crops have high moisture content during the time of harvest. Such crops deteriorate due to growth of mould, fungi, bacteria etc. (Ali \& Sakr 1981; Jayaraman \& Das Gupta 1987; Tayeb 1986). The basic principle of drying is to reduce the moisture content of the crops to a level that prevents deterioration within a certain period of time and to reduce the weight and volume of crops for cheaper storage and transport. Drying is a dual process of heat transfer from air to crops and mass transfer from crops to air (Midilli \& Kucuk 2003a). In this process moisture is extracted from the crops by heating and the released water vapour is carried away by the air mass flowing around it.

\subsection{Drying process}

When a product at constant moisture content is heated, the vapour pressure increases and results in movement of moisture from the product to its environment which is at a lower vapour pressure. The process consists of two periods; the constant drying rate and the falling drying rate (Ali \& Sakr 1981; Andales 1981; Carpio 1981; Fuller 1998; Hall 1957; Imre 1987; Midilli \& Kucuk 2003b; Suzuki et al. 1977). Fig. 2.1 illustrates the drying process.

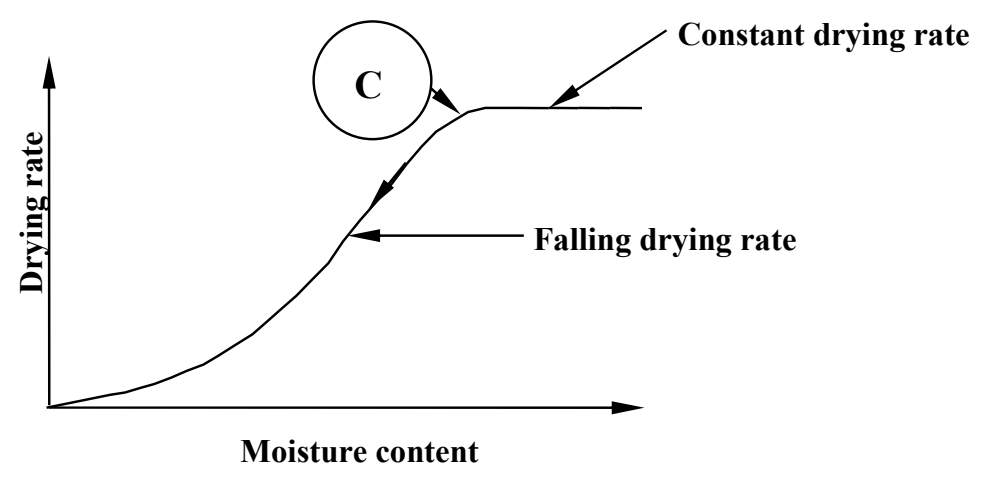

Fig. 2.1. Illustration of drying process 


\subsubsection{Constant rate period}

During this period, drying takes place from the surface of the product and the wet surface of the product behaves like a free water surface (Ali \& Sakr 1981; Hall 1957). For the constant rate drying process to continue, the moisture evaporated from the product's surface should be equal to the moisture supplied to the surface. In this case the drying rate is dependent on the area of product exposed to drying air, the vapour pressure difference between the drying air and product, the coefficient of mass transfer and the velocity of drying air (Ekechukwu 1999; Hall 1957, 1980). Drying of products like sand, stone, paper, washed seed and grain takes place in the constant rate period (Ekechukwu 1999; Hall 1957, 1980). The constant rate drying period is short for farm crops. Studies by Hossian and Bala (2002), and Gupta et al. (2002) found that chilli does not exhibit a constant rate drying period. All the drying occurs within the falling rate period. Thus, the constant rate is not pursued further in this study.

\subsubsection{Falling rate period}

The falling rate period occurs after the constant rate period. The critical moisture content is between the constant and falling rate periods (point $C$ in Fig. 2.1). In this case the drying rate is controlled by the movement of moisture from within the products to the surface by diffusion and removal of water from the surface. As the area of wet surface decreases, the rate of diffusion decreases and hence the drying rate. After some time, a point is reached where water can no longer diffuse to the surface as rapidly as it is evaporated and thus reaches an equilibrium moisture content.

In grain and forage, the critical moisture content is less than the initial moisture content, thus the drying takes place in the falling rate period (Hall 1957, 1980). However, for fruits and vegetables the initial moisture content is higher than the critical moisture content and thus drying occurs in both the constant and falling rate periods (Ekechukwu 1999). Even when the constant rate period exists, it is often neglected by the researchers owing to its very short period and the very small amount of water to be removed (Hall 1957, 1980). 


\subsection{Drying classification}

Drying of crops can be classified into two categories based on the thickness of the crop bed (Anwar \& Tiwari 2001; Ekechukwu 1999; Hall 1957). Drying bed thicknesses up to $20 \mathrm{~cm}$ are classified as thin bed drying while for more than $20 \mathrm{~cm}$, it is classified as deep bed drying (Anwar \& Tiwari 2001). Fig. 2.2 illustrates thin and deep layer drying.

\subsubsection{Thin layer drying}

In this case the crop is entirely exposed to the drying air flowing through it. The drying rate is dependent on the crop type, size and moisture content of crop and the drying temperature (Ekechukwu 1999; Hall 1957). Drying rate for thin bed drying during the falling rate period is based on Newton's law of cooling which states that "the rate of change in temperature of a body surrounded by a medium at constant temperature is proportional to the difference in temperature between the body and surrounding medium when the temperature difference is small” (Equation 2.1) (Hall 1957, 1980).

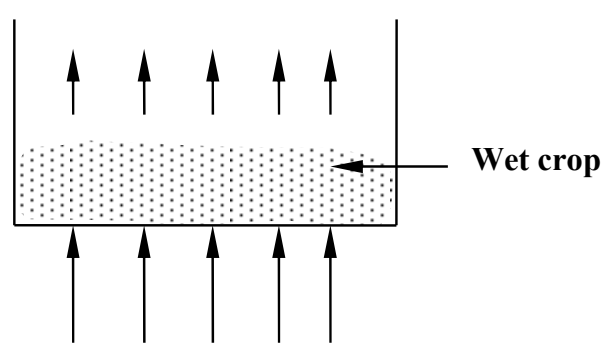

Air

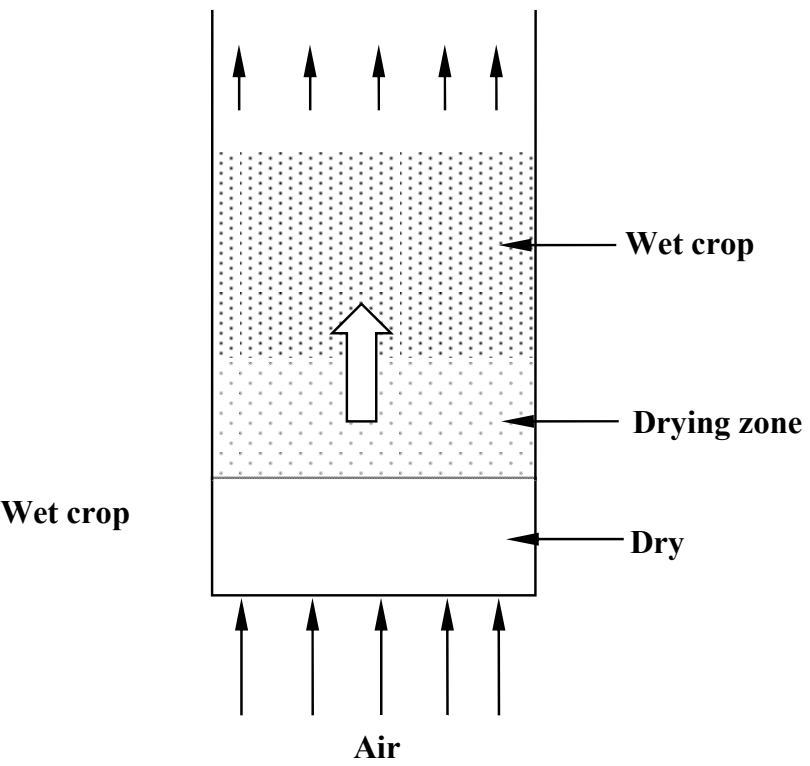

Deep layer drying

Thin layer drying

Fig. 2.2. Thin and deep layer drying 


$$
\begin{aligned}
\frac{d \theta}{d t} & =-k \times\left(\theta-\theta_{e}\right) \\
\text { Where } k & =\text { heating constant } \\
\theta & =\text { temperature at time } t \\
\theta_{e} & =\text { Surrounding medium temperature }\left({ }^{\circ} \mathrm{K}\right)
\end{aligned}
$$

By re-arranging and integrating Equation 2.1, an exponential equation is obtained as shown in Equation 2.2,

$$
\frac{\theta-\theta_{e}}{\theta_{o}-\theta_{e}} \quad=\quad e^{-k t}
$$

By substituting temperature $\theta$ by moisture content on dry basis, Equation 2.3 is obtained.

$$
\frac{M-M_{e}}{M_{o}-M_{e}} \quad=\quad e^{-k t}
$$

Here $M$ is the moisture content (db) at any time $t, M_{e}$ is the equilibrium moisture content, $M_{o}$ is the initial moisture content $(\mathrm{db})$ and $k$ is the drying constant.

\subsubsection{Deep layer drying}

In this case, drying of crops can be considered as several thin layers in which the humidity and temperature of air entering and leaving each layer varies with time depending on stage of drying. The main drying takes place in the drying zone which moves in the direction of air flow as shown in Fig 2.2. As the drying air flows, the crop layer where air enters dries faster than the upper layer and thus reaches a low moisture content level by the time the upper most layer reaches its equilibrium moisture content (Ekechukwu 1999; Hall 1957). The moisture content difference between the top and the bottom layer depends on the air flow. A higher air flow is associated with a lesser difference in moisture content.

\subsection{Drying parameters}

The rate of drying is affected by the properties of the drying air i.e. temperature, velocity of air flow and humidity. Ateba and Mittal (1994) considered most crops as porous and capillary material and thus the structure of the crop determines the rate of 
moisture migration from the inner layer to the surface of the crop. Also the method of preparation prior to drying, and shape and size of the piece affects the drying rate.

\subsubsection{Temperature}

The drying temperature differs with the type of food being dried. In general, the rate of drying increases with an increase in drying temperature (Lahsasni et al. 2004). Higher temperature also destroys bacteria, enzymes, fungi, eggs and larvae. However, there are some problems associated with higher temperatures. If the temperature of dryer air is high and humidity is low, then surface moisture will be removed faster than the interior moisture can move to the surface. This can harden the surface and retard the flow of interior moisture to the surface thus prohibiting the drying of the inner layer (Vlachos et al. 2002). This is further confirmed by Ali and Sakr's (1981) investigation of drying Jew's mallow and okra. They found that if the drying temperature and velocity of drying air are high, then the outer layer dries faster than the inner layers and, after being removed from the dryer, the surface becomes moist again due to reabsorption of moisture. Because of this Bansal and Misra (1987) recommended levels of temperature for each type of food products (Table 2.1).

Table 2.1. Recommended temperature for drying

\begin{tabular}{lccc}
\hline \multirow{2}{*}{ Product } & \multicolumn{2}{c}{ Moisture content } & \multicolumn{2}{c}{$\begin{array}{c}\text { Maximum temperature } \\
\text { allowable for drying }\left({ }^{\circ} \mathbf{C}\right)\end{array}$} \\
\cline { 2 - 3 } & Initial (\%) & Final (\%) & 70 \\
Bananas & 80 & 15 & 55 \\
Cabbage & 80 & 4 & 75 \\
Carrots & 70 & 5 & 65 \\
Cauliflower & 80 & 6 & 65 \\
Chilli & 80 & 5 & 55 \\
Garlic & 80 & 4 & 75 \\
Green beas & 70 & 5 & 65 \\
Green peas & 80 & 5 & 55 \\
Onions & 80 & 4 & 75 \\
Potatoes & 75 & 13 & 75 \\
Sweet potato & 75 & 7 & \\
\hline
\end{tabular}

Source: (Bansal \& Misra 1987) 
Warm air can hold more moisture than cold air, so the amount required depends on the temperature and absolute humidity when it enters the dryer. Table 2.2 shows the absorption capacity of air at different temperatures and relative humidifies

Table 2.2. Moisture absorption capacity (gm of water $/ \mathrm{m}^{3}$ of air)

\begin{tabular}{cccc}
\hline $\begin{array}{c}\text { Initial relative } \\
\text { humidity (\%) }\end{array}$ & Not heated $\left(\mathbf{2 0}^{\circ} \mathbf{C}\right)$ & Heated to $\mathbf{4 0}^{\circ} \mathbf{C}$ & Heated to $\mathbf{6 0}^{\circ} \mathbf{C}$ \\
\hline 40 & 4.3 & 9.2 & 16.3 \\
60 & 1.4 & 8.2 & 15.6 \\
80 & 0.0 & 7.1 & 14.9 \\
\hline
\end{tabular}

Source: (ITDG 2004a)

\subsubsection{Air flow}

At constant drying air temperature, the drying time decreases with an increase in air flow. The increase in velocity and volume of air flow results in a decrease in dryer temperature. A higher velocity means more air is available per unit time, so more heat and thus more water can be carried away in a given time. The rate of evaporation also depends on surface area and porosity of the particle. At constant air flow, the drying time decreases as the drying temperature increases and vice versa.

\subsubsection{Relative humidity}

The level of relative humidity also affects the drying time. Higher relative humidity is associated with less capacity to hold moisture, thus longer drying time. Also at higher humidity, more air will be required with a higher air temperature.

\subsection{Moisture content}

The percentage moisture content of crops can be expressed in two different ways (Exell 1980; Sharma et al. 1986):

- Wet basis - It is the ratio of weight of water to the total weight of dry matter plus water (Equation 2.4). 


$$
M C_{(\mathrm{wb})} \quad=\quad \frac{100 \times(W-W d)}{W}
$$

- Dry basis - It is the ratio of weight of water to the dry matter weight (Equation 2.5).

$$
M C(\mathrm{db}) \quad=\quad \frac{100 \times\left(W-W_{d}\right)}{W_{d}}
$$

Where $M C_{(w b)} \quad=\quad$ Moisture content on wet basis

$M C_{(d b)} \quad=\quad$ Moisture content on dry basis

$W \quad=\quad$ Weight of wet sample

$W_{d} \quad=\quad$ Weight of dry matter

The two moisture contents are inter-related by the Equations 2.6 and 2.7

$$
\begin{array}{lll}
M C_{(w b)} & = & 1-\left[\frac{1}{M C(d b)+1}\right] \\
M C_{(d b)} & = & {\left[\frac{1}{\left(1-M C_{(w b)}\right)}\right]-1}
\end{array}
$$

The dry basis moisture content is used for engineering calculations and research since the base of the ratio is constant with varying percentage moisture content (Bala 1997; Ekechukwu 1999; Hall 1980). Thus, in this study dry basis moisture content was used for calculations.

\subsubsection{Equilibrium moisture content}

Ambient air consists of dry air and water vapour. However, the ratio of water vapour to dry air is very small. The moisture content of the crops exposed to ambient air varies with respect to relative humidity. The greater the relative humidity, the greater uptake of moisture and vice versa. Although the uptake is slow, after some time a new value of moisture content is reached. Table 2.3 shows the equilibrium moisture content of different crops at various relative humidities. 
Table 2.3. Equilibrium moisture content

\begin{tabular}{lrrrrrrr}
\hline \multirow{2}{*}{ Crops } & \multicolumn{7}{c}{ Air Re lative humidity (\%) } \\
\cline { 2 - 8 } & $\mathbf{4 0}$ & $\mathbf{5 0}$ & $\mathbf{6 0}$ & $\mathbf{7 0}$ & $\mathbf{7 5}$ & $\mathbf{8 0}$ & $\mathbf{9 0}$ \\
\hline Wheat & 10.7 & 12.0 & 13.7 & 15.6 & 16.6 & 17.6 & 23.0 \\
Maize & 11.0 & 12.0 & 13.0 & 15.0 & 15.5 & 16.0 & 20.0 \\
Rye & 10.0 & 11.6 & 13.2 & 14.8 & 16.1 & 17.3 & 24.6 \\
Peas & 9.4 & 11.1 & 13.1 & 15.5 & 17.2 & 19.5 & 27.7 \\
Beans & 9.1 & 11.1 & 13.1 & 15.8 & 18.0 & 20.4 & 28.0 \\
Grass & 8.9 & 10.3 & 11.6 & 13.9 & 15.4 & 17.4 & 23.3 \\
Onions & 8.3 & 9.6 & 10.8 & 12.6 & 14.1 & 16.2 & 23.5 \\
\hline
\end{tabular}

Source: (FAO 1985)

The equilibrium moisture content (EMC) is dependent on the relative humidity and temperature of environment, and also on species, variety and maturity of the crop. It indicates whether the crop will absorb or lose moisture at a given temperature and relative humidity (Charm 1978). At the EMC, the rate of moisture loss from the crop is equal to the rate of moisture gain of the crop from the atmosphere (Hall 1980). EMC could be classified into two types i.e. static and dynamic equilibrium moisture content (Bala 1997). Static EMC is obtained after prolonged exposure of the crop to the atmosphere while the dynamic EMC is obtained by fitting the thin layer drying equation to experimental data (Bala 1997). Ward et al. (1954 in Bala 1997) recommended that static and dynamic EMC should be used for storage and drying respectively.

The relationship between EMC and relative humidity at a constant temperature is illustrated by a curve called an isotherm. Fig. 2.3 shows a typical isotherm curves for an agricultural crop. An adsorption isotherm indicates moisture content versus relative humidity of the crop subjected to absorption of moisture while a desorption isotherm indicates a drying phenomenon. 


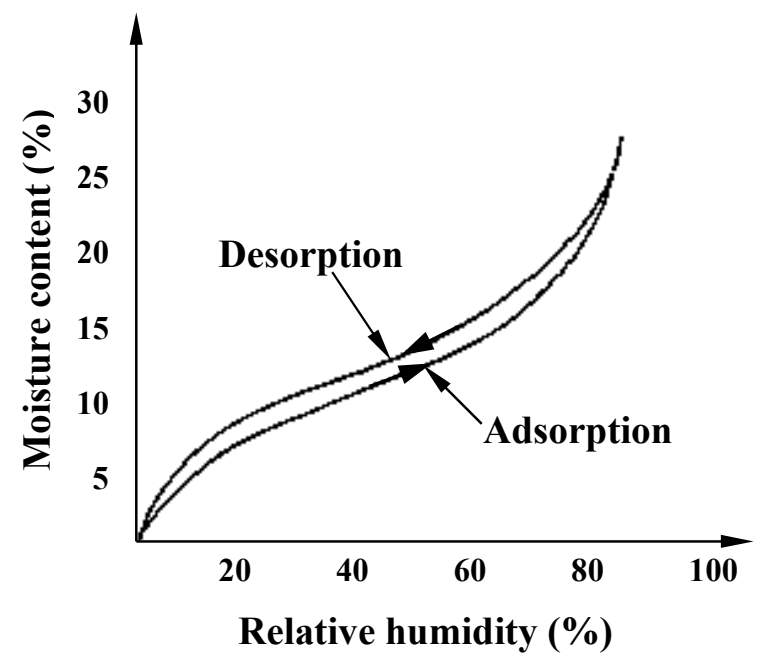

Fig. 2.3. Adsorption and desorption isotherms

\subsection{Properties of chilli and beef}

\subsubsection{Chilli}

Sitthiphong et al. (1989) investigated the physical properties of the green chillies in Thailand. The diameter and length of chillies were recorded as 10 to $15 \mathrm{~mm}$ and 100 to $200 \mathrm{~mm}$ respectively, while Kalemullah and Kailappan (2003) found that since the cylindricity value $(86.9 \%)$ was more than the sphericity value $(60.9 \%)$, chillies can thus be considered to be cylindrical. The bulk density of wet chilli at $83 \%$ moisture content was $325 \mathrm{~kg} / \mathrm{m}^{3}$ while dry chilli at $13 \%$ moisture content was $80 \mathrm{~kg} / \mathrm{m}^{3}$ (Sitthiphong et al. 1989). The green chilies were found to bleach when exposed to temperature above $45^{\circ} \mathrm{C}$, red chillies do not bleach regardless of drying temperature (Reilly 1996). This was explained by Reilly (1996) to be due to the presence of colour pigment anthocyanin in red chillies, which is less sensitive to damage by light compared to the chlorophyll present in green chillies, which is highly sensitive to damage by light and heat. As only red chillies are dried in Bhutan, the problem of bleaching does not arise.

Pruthi (1993) and Miaruddin et al. (1995 in Hossian \& Bala 2002) reported a moisture content of 70 to $80 \%$ during the time of harvest and recommended a final moisture 
content of 8 to $10 \%$ for storage and 4 to $5 \%$ for grinding purposes. Also Bansal and Misra (1987) found the moisture content of fresh chilli to be $80 \%$ while Kaleemullah and Kailappan (2003) report a moisture content of 75 to $80 \%$ at full maturity. Bosland and Votava (2003) recommended a final moisture content of 8 to $11 \%$ for safe storage. Dogantan et al. (1987) noted an initial moisture content of $80 \%$ and $10 \%$ for storage. However, if too much moisture is removed, then the colour may fade rapidly but on the other hand, mould may grow if the moisture content is high. Table 2.4 summarises the parameters of the chilli used in this study based on the literature.

Table 2.4: Parameters of chilli used in this study

\begin{tabular}{lrc}
\hline \multicolumn{1}{c}{ Parameters } & Value & Unit \\
\hline Initial moisture content & 567 & $\%$ \\
Final moisture content & 10 & $\%$ \\
Bulk density (fresh) & 325 & $\mathrm{~kg} / \mathrm{m}^{3}$ \\
Length & $100-200$ & $\mathrm{~mm}$ \\
Diameter & $10-15$ & $\mathrm{~mm}$ \\
\hline
\end{tabular}

\subsubsection{Meat (beef)}

Traditionally, meat is dried by slicing into strips and hanging over ropes or wires without any cover. There is no standard length or thickness for the strips. FAO (1990) recommended that the length of the strips be 20 to $70 \mathrm{~cm}$, however, in Bhutan the longer strips are considered better to prepare traditional meals. Before slicing the meat, it is de-boned and separated from tissues, however, fats are not removed for drying. Normally, it takes 5 to 7 days to dry beef by the natural sun drying method. The meat is dried until the strips break off when bent. The moisture content of fresh beef was estimated as 70\% (wb) by ITDG (2004b) while Holley (1985) considered it to be $68 \%$ (wb). Further Lisse and Wack (1998) reported the moisture content of beef strips as 80 $\pm 1.1 \%$ (wb). Fuller and Lu Aye (2002) considered the initial moisture content of beef as $80 \%$. In this study, an initial moisture content of $80 \%$ will be assumed equal to the values assumed by Lisse and Wack (1998) and Fuller and Lu Aye (2002). 


\subsection{Methods of drying}

In general, crop dryers can be grouped into two groups: Traditional sun drying and conventional drying methods. As reported in Section 1.1, traditional sun drying is a slow process and losses may reach 30 to $40 \%$ in tropical countries (Costa et al. 2003) and require approximately one acre of drying surface per 20 acres of crop land (Desrosier 1970 pp 124). While conventional dryers have high efficiency and produce a uniform high quality product, they are expensive, and so not affordable by rural farmers (Ivanova \& Andonov 2001). Lutz et al. (1987) reported that even the smallest and most simple oil or gas fired conventional dryers could not be applied in small scale firms. Thus, an alternative approach is to use a solar dryer which uses free solar energy available from the sun's radiation. Most agricultural products are harvested during the summer months when solar radiation is high (Maroulis \& Saravacos 1986). This increases the opportunity to use solar energy for crop drying. The next section describes solar dryers in detail.

\subsection{Conclusions}

The drying processes of any products have been explained in the preceding sections. Drying process can be summarised as evaporation of the water content of product from the surface to the surrounding medium and movement of water from inside the product to the surface by means of diffusion. Drying needs heat to evaporate water from the product and a medium to carry away water from the surface. Air is used both as a medium to transfer heat to the product as well as to carry away the water from the surface. However, air has to be heated to a certain level of temperature based on a safe drying temperature to increase the moisture absorption capacity. This requires an external energy source which makes mechanical dryers expensive in developing countries. Thus solar dryers are preferred as abundant and free solar energy is available from the sun's radiation. 


\subsection{References}

Ali, HM and Sakr, IA 1981, 'Drying of Vegetables in Egypt', paper presented to Food Drying, Edmonton, Alberta, Canada, 6-9 July 1981.

Andales, SC 1981, 'Drying of Cereal Grains in the Philippines', paper presented to Food Drying, Edmonton, Alberta, Canada, 6-9 July 1981.

Anwar, SI and Tiwari, GN 2001, 'Evaluation of convective heat transfer coefficient in crop drying under open sun drying conditions', Energy Conversion and Management, vol. 42, no. 5, pp. 627-37.

Ateba, P and Mittal, GS 1994, 'Modelling the deep-fat frying of meatballs', International Journal of Food Science and Technology, vol. 29, pp. 429-40.

Bala, BK 1997, Drying and Storage of Cereal Grains, Science Publishers, Inc., Enfield, New Hampshire, USA.

Bansal, HK and Misra, A 1987, 'Plastic Film Solar Air Heater for Crop Drying', paper presented to European Cooperative Networks on Rural Energy Technical Meeting, Stutgart, Federal Republic of Germany, 9 - 11 September 1987.

Bosland, PW and Votava, E 2003, Peppers: Vegetable and Spice Capsicums, CABI Publishing, Wallingford, U.K.

Carpio, EV 1981, 'Drying Fish in the Philippines', paper presented to Food Drying, Edmonton, Alberta, Canada, 6-9 July 1981.

Charm, SE 1978, The Fundamentals of Food Engineering, AVI Publishing Company, Inc., Westport, Connecticut, USA. 
Costa, ARS, Viera Nunes, AI, Araujo, AA, Ferreira, SR and Melo, MAF 2003, Natural Drying Process for Tropical Fruits, 395, Department of Chemical Engineering, University of Rio Grande do Norte, Natal-RN, Brazil.

Desrosier, NW 1970, The Technology of Food Preservation, 3 edn, The Avi Publishing Company, Westport, Connecticut, United States of America.

Dogantan, ZS, Tuncer, IK and Bascetincelik, A 1987, 'Use of Solar Energy for Red Pepper Drying', paper presented to European Cooperative Networks on Rural Energy Technical Meeting, Stutgart, Federal Republic of Germany, 9 - 11 September 1987.

Ekechukwu, OV 1999, 'Review of solar-energy drying systems I: an overview of drying principles and theory', Energy Conversion and Management, vol. 40, no. 6, pp. 593-613.

Exell, RHB 1980, 'Basic Design Theory for a Simple Solar Rice Dryer', Renewable Energy Review Journal, vol. 1, no. 2, pp. 1 - 14.

FAO 1985, Prevention of post-harvest food losses: a training manual, Food and Agriculture Organisation, Viale delle Terme di Caracalla, Rome, Italy.

FAO 1990, Manual on simple methods of meat preservation, 79, Food and Agriculture Organisation of the United Nations, Rome, Italy.

Fuller, B 1998, Harnessing the Sun: Solar drying your own produce, Bolwarrah Press, Bolwarrah, Victoria, Australia.

Fuller, RJ and Lu Aye 2002, 'Design of a Solar Assisted meat dryer', paper presented to Solar Harvest 2002, Newcastle, Australia, 27-30 November 2002. 
Gupta, P, Ahmed, J, Shivare, US and Raghavan, GSV 2002, 'Drying Characteristics of Red Chilli', Drying Technology, vol. 20, no. 10, pp. 1975-87.

Hall, CW 1957, Drying Farm Crops, Agricultural Consulting Associates, Inc., Engineering Specialists, Reynoldsburg, Ohio, USA.

Hall, CW 1980, Drying and Storage of Agricultural Crops, AVI Publishing Company, Inc., Westport, Connecticut, USA.

Holley, RA 1985, 'Beef Jerky: Viability of food-poisoning microorganisms on Jerky during its manufacture and storage', Journal of food protection, vol. 48, no. 2, pp. $100-6$.

Hossain, MA and Bala, BK 2002, 'Thin-Layer Drying Characteristics for Green Chilli', Drying Technology, vol. 20, no. 2, pp. 489-505.

ITDG 2004a, Solar Drying, Intermediate Technology Development Group, viewed 27 August 2004, $<\underline{\text { http://www.itdg.org/html/technical_enquiries/docs/solar_drying.pdf }>}$.

ITDG 2004b, Drying of Foods, Intermediate Technology Development Group, viewed 27 August 2004, $<$ http://www.itdg.org/html/technical_enquiries/docs/drying_of foods.pdf $>$.

Imre, LL 1987, 'Solar Drying', in AS Mujumdar (ed.), Handbook of Industrial Drying, Marcel Dekker, Inc., New York, USA, p. 948.

Ivanova, D and Andonov, K 2001, 'Analytical and experimental study of combined fruit and vegetable dryer', Energy Conversion and Management, vol. 42, no. 8, pp. $975-83$. 
Jayaraman, KS and Das Gupta, DK 1987, 'Drying of Fruits and Vegetables', in AS Mujumdar (ed.), Handbook of Industrial Drying, Marcel Dekker, Inc., New York, USA, p. 948.

Kaleemullah, S and Kailappan, R 2003, 'Geometric and Morphometric Properties of Chillies', International Journal of Food Properties, vol. 6, no. 3, pp. 481-98.

Lahsasni, S, Kouhila, M, Mahrouz, M, Idlimam, A and Jamali, A 2004, 'Thin layer convective solar drying and mathematical modeling of prickly pear peel (Opuntia ficus indica)', Energy, vol. 29, no. 2, pp. 211-24.

Lisse, I and Wack, ALR 1998, 'Drying of meat materials (lean and fat) by deep-fat frying in animal fat', Sciences Des Aliments, vol. 18, no. 4, pp. 423-35.

Lutz, K, Muhlbauer, W, Muller, J and Reisinger, J 1987, 'Development of a MultiPurpose Solar Crop Dryer for Arid Zones', paper presented to European Cooperative Networks on Rural Energy Technical Meeting, Stutgart, Federal Republic of Germany, 9 - 11 September 1987.

Maroulis, ZB and Saravacos, GD 1986, 'Solar heating of air for drying agricultural products', Solar \& Wind Technology, vol. 3, no. 2, pp. 127-34.

Midilli, A and Kucuk, H 2003a, 'Energy and exergy analyses of solar drying process of pistachio', Energy, vol. 28, no. 6, pp. 539-56.

Midilli, A and Kucuk, H 2003b, 'Mathematical modeling of thin layer drying of pistachio by using solar energy', Energy Conversion and Management, vol. 44, no. 7 , pp. 1111-22.

Reilly, ID 1996, 'Development and evaluation of a natural convection solar drier', Master of Engineering Science thesis, The University of Melbourne. 
Sharma, VK, Sharma, S, Ray, RA and Garg, HP 1986, 'Design and performance studies of a solar dryer suitable for rural applications', Energy Conversion and Management, vol. 26, no. 1, pp. 111-9.

Sitthiphong, N, Hirun, A, Klongpanich, W, Thertoon, P, Siratanapanta, T, Thavornun, S and Kamalaspitak, S 1989, Final Report Chapter 2: Multi-Crop Dryers Project First Phase (1986 - 1988), The International Development Research Centre, Canada.

Suzuki, M, Keey, RB and Maeda, S 1977, 'On the characteristic drying curve', paper presented to Water removal process: drying and concentration of foods and other materials, New York.

Tayeb, AM 1986, 'Modern solar grain dryer', Solar \& Wind Technology, vol. 3, no. 3, pp. 211-4.

Vlachos, NA, Karapantsios, TD, Balouktsis, AI and Chassapis, D 2002, 'Design and Testing of a New Solar Tray Dryer', Drying Technology, vol. 20, no. 6, pp. 124371. 


\section{SOLAR DRYERS}

\subsection{Introduction}

Solar drying is a method of sun drying (ITDG 2004). A solar crop dryer can reduce spoilage, waste, insect infestation, attack by rodents and birds compared to the traditional method of drying. Solar drying of crops also improves the quality of produce considerably (Bansal \& Misra 1987; Farkas \& Smith 1987; Lahsasni et al. 2004; Lutz et al. 1987). Several studies in different countries indicate that solar dryers can be effectively used for drying crops and it is a question of designing the right type of solar dryer (Esper \& Muhlbauer 1998; Gallali et al. 2000; Pangavhane \& Sawhney 2002).

\subsection{Types of solar dryers}

Ekechukwu and Norton (1999a) and Leon et al. (2002) classified solar dryers into two groups: active dryers and passive dryers. Both types were further classified into three types of integral, distributed and mixed mode solar dryers.

\subsubsection{Active and Passive solar dryers}

Active and passive solar dryers are differentiated, based on the method of air convection inside the dryer. Active solar dryers use a fan to circulate the air while passive solar dryers do not require an external fan. The warm air inside the dryer is lighter than the cooler air outside. The difference in density creates a pressure difference which forces the air through the dryer. Thus, active and passive solar dryers are also commonly known as forced and natural convection solar dryers respectively.

In general, natural convection solar dryers are preferred by the farmers due to the relatively simple construction, operation and low cost (Soponronnarit 1995). However Ekechukwu and Norton (1998) noted that natural convection solar dryers are highly dependent on weather conditions. For example, the performance of a solar dryer was 
better during dry summer months, requiring two days less than in winter to dry the same quantity of cassava chips.

\subsubsection{Integral and distributed solar dyers}

Integral and distributed solar dryers are differentiated by the mode of utilising solar radiation (Vlachos et al. 2002). In the case of integral solar dryers, the collector is an integral part of the drying unit. In this type, the crop absorbs the solar radiation directly. Direct solar dryers are simple to operate but it is difficult to control the temperature.

Unlike integral solar dryers, distributed solar dryers consist of separate units of solar collector and dryer. In this type, the crop is not exposed to direct radiation but is heated by convection by the heated air. Thus, integral and distributed solar dyers are also commonly known as direct and indirect solar dryers respectively.

\subsection{Solar air collectors}

Collectors are devices employed to absorb useful energy from incident solar radiation. Solar collectors are of two types: concentrating and flat plate (Ekechukwu \& Norton 1999b). Concentrating collectors operate at higher temperatures than flat plate collectors. Furthermore Ekchukwu and Norton (1999b) classified flat plate collectors into two groups: bare plate and covered plate, while Soponronnarit (1995) classified collectors into three types: flat plate, non-flat plate and integrated collector storage. For solar crop dryers, flat plate collectors are more appropriate as they are simple, economical and provide the desired temperatures (Ekechukwu \& Norton 1999b; Soponronnarit 1995). Thus only flat plate solar collectors are dealt with in detail in this report.

Flat plate solar collectors are further classified into bare flat plat, covered flat plate and covered flat plat with a still air gap. Fig. 3.1 shows three types of flat plate solar collectors. 


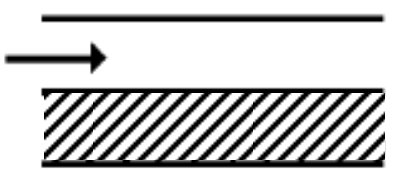

(a) Bare flat plate

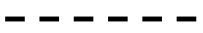

Transparent cover

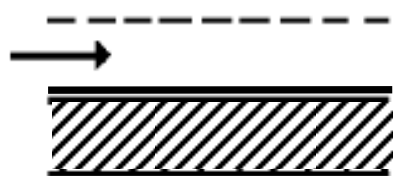

(b) Covered flat plate

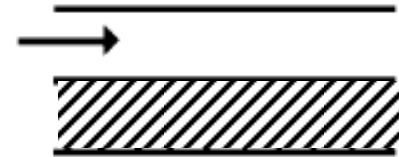

(c) Covered flat plate with still air gap

Fig. 3.1. Flat plate solar collector

Source: (Soponronnarit 1995)

Bare flat plate collectors are the simplest form of solar collectors. These consist of an air duct with an insulted rear surface. The upper surface acts as a solar energy absorber. These collectors are associated with high thermal losses due to their exposed surfaces and thus have lower thermal efficiency. Bare flat plat solar collectors are suitable for low temperature solar drying and are widely used in both natural and forced convection solar dryer systems due to their low cost of construction.

Similarly, covered flat plate collectors also consist of an air duct with an insulated rear surface but the upper surface is covered with either glass or polyethylene sheet. Although the transmission of incoming solar radiation is reduced by about $10 \%$, the thermal efficiency is higher compared to bare flat plate solar collectors due to minimised radiation and convection losses (Sodha et al. 1987 in Ekechukwu \& Norton 1999b), however, they are more expensive compared to bare flat plate solar collectors. These collectors are recommended for higher temperature uses.

The covered flat plate with a still air gap also consists of an air duct with an insulated rear surface and an extra layer of static air between the cover and the absorber plate. Soponronnarit (1990) studied bare and glass cover solar collectors. The results showed that the use of bare flat plate solar collectors is technically viable at low wind speed 
and air speed inside collector should be 4 to $6 \mathrm{~m} / \mathrm{s}$ with a corresponding air flow of 0.015 to $0.023 \mathrm{~kg} / \mathrm{s} / \mathrm{m}^{2}$, while covered flat plate collectors could be used either at low or high wind speed with higher efficiency. Corrugated iron (CGI) sheets are often used for flat plate collectors (Ekechukwu \& Norton 1999b; Lahsasni et al. 2004; Proctor 1994; Sharma et al. 1986; Soponronnarit 1988; Soponronnarit et al. 1986) due to their large surface area, wide availability and low cost.

\subsubsection{Efficiency of collectors}

The efficiency of the collector varies with the type of collector material used. Exell (1980) acknowledged that efficiency is not always known with certainty and assumed it to be $25 \%$ for estimation purposes. However, James (1992) and Sharma et al. (1986) assumed the efficiency of collectors as 40\%. Soponronnarit et al. (1986) conducted an experimental investigation of efficiency of flat plate collector using CGI sheets at flow rate of $0.018 \mathrm{~kg} / \mathrm{s} / \mathrm{m}^{2}$. The minimum efficiency was recorded as $29 \%$. Similar tests by same author in 1988 resulted in a collector efficiency of 30\% and 34\% for unpainted and black painted CGI sheets respectively (Soponronnarit 1988).

\subsection{Solar drying of crops}

Lutz et al. (1987) investigated the time taken to dry grapes using the traditional drying method and solar drying. Natural sun drying took 8 - 12 days to dry while solar dryers took 4 - 7 days depending on the weather conditions. Bala et al. (2003) also compared the drying time of pineapples with natural sun drying using tunnel dryers. The results found that it took three days to reduce moisture content from $87 \%$ to $14 \%$ using solar tunnel dryers while for same period using natural sun drying, the final moisture content was $21 \%$, while Pangavhane et al. (2002) reported that drying times of grapes were reduced by $43 \%$ by a natural convection solar dryer compared to open sun drying.

Simate (2003) found that mixed mode natural convection drying required a shorter collector length $(1.8 \mathrm{~m})$ as compared to an indirect dryer collector $(3.34 \mathrm{~m})$ for the same grain capacity. Ivanova et al. (2003) estimated a saving of $17.7 \%$ of the annual heating load during the day by using solar energy to heat the working fluid of a solar 
dryer. Farkas and Smith (1987) mentioned that by applying a microcomputer assisted automatic control system to solar dryers, product quality can be ensured at optimum use of available solar radiation. However such advanced technology would not be feasible in rural Bhutan.

\subsubsection{Solar drying of chilli}

Tiris et al. (1995) investigated the drying time of chilli peppers using the solar air heaters. The drying time was found to be shorter by 2.0 days using the solar air heaters in comparison to a natural sun drying which normally took 6 to 10 days to achieve same final moisture content, while Korel et al. (2002) reported a drying time of 14 days using natural sun drying. Furthermore, Singhagajen (1981) reported that the solar dryer reduced the drying time of chilli by one third of natural sun drying. Also, an experimental investigation found that solar drying reduced the drying time by 2.8 times compared to natural sun drying of chilli at a mass flow rate of 150 to $250 \mathrm{~kg} / \mathrm{m}^{2} \mathrm{~h}$ (Tiris et al. 1996). Reducing the thickness of drying material from $10 \mathrm{~cm}$ to $5 \mathrm{~cm}$ decreased the drying time by 30\% (Dogantan et al. 1987). Also slicing of the chilli decreased the drying time by $60 \%$. Further, Jensen et al. (1999) reported that it took 3 to 4 days to reach a final moisture content of $12 \%$ using natural convective solar dryers.

Mastekbayeva et al. (2000) compared the drying time of green chilli using natural sun drying and a solar-biomass hybrid dryer. While the later required 21 hours to reduce moisture content from $76 \%-6.6 \%$ wet basis, the former took five days to achieve same level of final moisture content.

\subsubsection{Solar drying of beef}

There is very little public information on drying of beef in general and solar drying in particular. Whatever literature is available is mostly based on the drying of meat by deep frying and on the meat based products. For example, Simal et al. (2003) studied the drying mechanism of meat based products like sobrassada and nothing was mentioned about the meat, while Lisse and Wack (1998) studied drying of meat by deep-fat frying. The later results indicated that frying time ranged from 17 to 90 minutes to reach a final moisture content of $8 \%$ from an initial moisture content of 56 - 
$80 \%$. The time depended on the temperature of frying oil. Increasing the temperature of oil reduced the dying time by a factor of 2.3. Similarly, Mittal and Zhang (2001) used an artificial neural network to predict the temperature and moisture content of meatballs during deep-fat frying.

Holley (1985) investigated drying of meat jerky using an electric dehydrator. The results showed that the moisture content was reduced from $68 \%$ to $20 \%$ after drying for eight hours at $50^{\circ} \mathrm{C}$. Also Jensen et al. (1999) reported that it took five days to reduce moisture content of meat from 65 to $12 \%$ using natural convective solar dryers in Ghana. Fuller and Lu Aye (2002) designed a solar assisted meat dryer. The dryer was designed to dry meat at $50^{\circ} \mathrm{C}$ for 10 hours from $400 \%(\mathrm{db})$ to $10 \%(\mathrm{db})$. The simulation results showed that the solar contribution to the load was $49 \%$.

\subsection{Back-up heating}

Since solar energy is highly intermittent and variable, a back-up heating source is required to avoid growth of pathogens and moulds and re-absorption of moisture during the periods of low or zero solar radiation. Charters and Pryor (1982) noted that it is not economic to design a solar thermal system to support $100 \%$ load. This is mainly due to high cost of solar collectors and other accessories. Also it may be oversized during the high solar period. Thus a back-up energy source is necessary and should be able to provide full load during the poor weather periods. This will supplement solar energy during the day time and will provide $100 \%$ of the load if used during the night.

\subsection{Scope for solar drying in Bhutan}

As seen in Section 1.2, about 33\% of the total chilli produced in Bhutan was traded in 2000 (MoA 2000). This includes both fresh and dried chilli. The loss of chilli due to inefficient drying in Bhutan is not reported and is still unknown. Dongantan et al. (1987) reported that in the K Moras district of Turkey about $20 \%$ of the total chilli harvest was lost as a result of inefficient traditional drying methods. In this researcher's experience, the loss due to inefficient drying in Bhutan may not be lower 
than this value. In Bhutan, the farms are all family owned and there is no system of commercial farming. The chillies that are traded in the markets are all surplus production. Thus it is unlikely that every house can afford a solar dryer for their own use. So an alternative approach is to install a solar dryer in one village and operate on a cooperative yet commercial basis.

Moreover, the solar dryer may be less attractive if it is to be used for drying crops for household consumption. Also the cost of drying per unit of crops needs to be as low as possible so that the financial benefits of using a solar dryer are high. This requires that the technology proposed in every developing country makes use of local raw materials, traditional skills and local energy sources (Hodali \& Bougard 2001). In line with this, Singh et al. (2004) designed a portable solar dryer, which could be dismantled, for use in villages. This included an option to dry the product under shade or without shade. The thermal efficiency was reported to be $28.5 \%$. But one design may not suit the needs of different users in different places as the availability of solar energy varies with geographical area, with time of the year and with weather conditions. Thus it is desired that systems are designed to match the climate where they are going to be located, so a proper study is necessary before producing the dryers.

However, to study the performance of a solar dryer during different times of a year and at various locations requires climatic data for that location. Ali and Sakr (1981) claimed that at least ten years meteorological data is necessary to obtain a good average. A search of the literature revealed that Bhutan neither has a meteorological station nor has any attempt been made to generate climatic data. Thus, the first step in this study is to generate meteorological data for Bhutan using the methods available in the literature. Therefore Section 4 explains in detail the generation of meteorological data for Bhutan.

\subsection{Conclusions}

The different types of solar dryers have been explained in the preceding sections. The benefits of using solar dryers are immense but the acceptance of this is still very low in the developing countries. The reasons for the low acceptance rate call for appropriate 
technology that suits the developing countries. Any proposed technology needs proper evaluation before implementing it. To assess the performance of a solar crop dryer requires meteorological data for the location proposed which Bhutan has none at the time of this study. Thus the next section describes the generation of meteorological data for Bhutan.

\subsection{References}

Ali, HM and Sakr, IA 1981, 'Drying of Vegetables in Egypt', paper presented to Food Drying, Edmonton, Alberta, Canada, 6-9 July 1981.

Bala, BK, Mondol, MRA, Biswas, BK, Das Chowdury, BL and Janjai, S 2003, 'Solar drying of pineapple using solar tunnel drier', Renewable Energy, vol. 28, no. 2, pp. 183-90.

Bansal, HK and Misra, A 1987, 'Plastic Film Solar Air Heater for Crop Drying', paper presented to European Cooperative Networks on Rural Energy Technical Meeting, Stutgart, Federal Republic of Germany, 9 - 11 September 1987.

Charters, WWS and Pryor, TL 1982, Theory and Design of Solar Thermal Systems, Victorian Solar Energy Council, Melbourne, Australia.

Dogantan, ZS, Tuncer, IK and Bascetincelik, A 1987, 'Use of Solar Energy for Red Pepper Drying', paper presented to European Cooperative Networks on Rural Energy Technical Meeting, Stutgart, Federal Republic of Germany, 9 - 11 September 1987.

Ekechukwu, OV and Norton, B 1998, 'Effects of seasonal weather variations on the measured performance of a natural-circulation solar-energy tropical crop dryer', Energy Conversion and Management, vol. 39, no. 12, pp. 1265-76. 
Ekechukwu, OV and Norton, B 1999a, 'Review of solar-energy drying systems II: an overview of solar drying technology', Energy Conversion and Management, vol. 40 , no. 6 , pp. 615-55.

Ekechukwu, OV and Norton, B 1999b, 'Review of solar-energy drying systems III: low temperature air-heating solar collectors for crop drying applications', Energy Conversion and Management, vol. 40, no. 6, pp. 657-67.

Esper, A and Muhlbauer, W 1998, 'Solar drying - an effective means of food preservation', Renewable Energy, vol. 15, no. 1-4, pp. 95-100.

Exell, RHB 1980, 'Basic Design Theory for a Simple Solar Rice Dryer', Renewable Energy Review Journal, vol. 1, no. 2, pp. 1 - 14.

Farkas, I and Smith, CC 1987, 'Computer Simulation and Control of a Solar Crop Dryer', paper presented to European Cooperative Networks on Rural Energy Technical Meeting, Stutgart, Federal Republic of Germany, 9 - 11 September 1987.

Fuller, RJ and Lu Aye 2002, 'Design of a Solar Assisted meat dryer', paper presented to Solar Harvest 2002, Newcastle, Australia, 27-30 November 2002.

Gallali, YM, Abujnah, YS and Bannani, FK 2000, 'Preservation of fruits and vegetables using solar drier: a comparative study of natural and solar drying, III; chemical analysis and sensory evaluation data of the dried samples (grapes, figs, tomatoes and onions)', Renewable Energy, vol. 19, no. 1-2, pp. 203-12.

Hodali, R and Bougard, J 2001, 'Integration of a desiccant unit in crops solar drying installation: optimisation by numerical simulation', Energy Conversion and Management, vol. 42, no. 13, pp. 1543-58. 
Holley, RA 1985, 'Beef Jerky: Viability of food-poisoning microorganisms on Jerky during its manufacture and storage', Journal of food protection, vol. 48, no. 2, pp. $100-6$.

ITDG 2004, Solar Drying, Intermediate Technology Development Group, viewed 27 August 2004, $<\underline{\text { http://www.itdg.org/html/technical_enquiries/docs/solar_drying.pdf }>\text {. }}$

Ivanova, D, Enimanev, K and Andonov, K 2003, 'Energy and economic effectiveness of a fruit and vegetable dryer', Energy Conversion and Management, vol. 44, no. 5, pp. 765-71.

James, KR 1992, 'Design of solar crop dryer for fruit', Master of Engineering Science thesis, The University of Melbourne, Australia.

Jensen, So, Frank, FC and Kristensen, EF 1999, Survey on solar dryers for drying of food and wood in Ghana, SEC-R-4, Danish Institute of Agricultural Sciences.

Korel, F, Bagdatlioglu, N, Balaban, MO and Hisil, Y 2002, 'Ground Red Peppers: Capsaicinoids Content, Scoville Scores, and Discrimination by an Electronic Nose', Journal of Agriculture and Food Chemistry, vol. 50, no. 11, pp. 3257-61.

Lahsasni, S, Kouhila, M, Mahrouz, M, Idlimam, A and Jamali, A 2004, 'Thin layer convective solar drying and mathematical modeling of prickly pear peel (Opuntia ficus indica)', Energy, vol. 29, no. 2, pp. 211-24.

Leon, MA, Kumar, S and Bhattacharya, SC 2002, 'A comprehensive procedure for performance evaluation of solar food dryers', Renewable and Sustainable Energy Reviews, vol. 6, no. 4, pp. 367-93.

Lisse, I and Wack, ALR 1998, 'Drying of meat materials (lean and fat) by deep-fat frying in animal fat', Sciences Des Aliments, vol. 18, no. 4, pp. 423-35. 
Lutz, K, Muhlbauer, W, Muller, J and Reisinger, J 1987, 'Development of a MultiPurpose Solar Crop Dryer for Arid Zones', paper presented to European Cooperative Networks on Rural Energy Technical Meeting, Stutgart, Federal Republic of Germany, 9 - 11 September 1987.

Mastekbayeva, GA, Bhatta, CP, Leon, MA and Kumar, S 2000, 'Experimental studies on a hybrid dryer', paper presented to The 1999 Jerusalem Solar World Congress, Jerusalem, Israel.

Mittal, GS and Zhang, J 2001, 'Artificial neural network for the prediction of temperature, moisture and fat contents in meatballs during deep-fat frying', International Journal of Food Science and Technology, vol. 36, pp. 489-97.

MoA 2000, Renewable Natural Resources Statistics 2000, Ministry of Agriculture, Thimphu, Bhutan.

Pangavhane, DR and Sawhney, RL 2002, 'Review of research and development work on solar dryers for grape drying', Energy Conversion and Management, vol. 43, no. 1, pp. 45-61.

Pangavhane, DR, Sawhney, RL and Sarsavadia, PN 2002, 'Design, development and performance testing of a new natural convection solar dryer', Energy, vol. 27, no. 6, pp. 579-90.

Proctor, DL 1994, Grain storage techniques: Evolution and trends in developing countries, 109, Food and Agriculture Organisation of the United Nations (FAO), Rome, 1994.

Sharma, VK, Sharma, S, Ray, RA and Garg, HP 1986, 'Design and performance studies of a solar dryer suitable for rural applications', Energy Conversion and Management, vol. 26, no. 1, pp. 111-9. 
Simal, S, Femenia, A, Garcia-Pascual, P and Rossello, C 2003, 'Simulation of the drying curves of a meat-based product: effect of the external resistance to mass transfer', Journal of Food Engineering, vol. 58, no. 2, pp. 193-9.

Simate, IN 2003, 'Optimisation of mixed-mode and indirect-mode natural convection solar dryers', Renewable Energy, vol. 28, no. 3, pp. 435-53.

Singh, S, Singh, PP and Dhaliwal, SS 2004, 'Multi-shelf portable solar dryer', Renewable Energy, vol. 29, no. 5, pp. 753-65.

Singhagajen, S 1981, 'Farm Grain Dryer - Thailand', paper presented to Food Drying, Edmonton, Alberta, Canada, 6-9 July 1981.

Sodha, MS, Bansal, NK, Kumar, K, Bansal, PK and Malik, MAS 1987, 'Solar Crop Drying', C.R.C. Press, Palm Beach, Florida, USA, vol. 1.

Soponronnarit, S 1988, 'Review of Research and Development Work on Forced Convection Solar Drying in Thailand', Regional Energy Resources Information Centre International Journal, vol. 10, no. 1, pp. 19-27.

Soponronnarit, S 1990, 'Studies of Bare and Glass-Cover Flat-Plate Solar Air Heaters', Regional Energy Resources Information Centre International Journal, vol. 12, no. 1, pp. 1-19.

Soponronnarit, S 1995, 'Solar Drying in Thailand', Energy for Sustainable Devlopment, vol. 2, no. 2, pp. 19 - 25.

Soponronnarit, S, Watabutr, W, Therdyothin, A and Kunjara, B 1986, 'A DryingStorage Solar Hut: The Technical Aspects', Renewable Energy Review Journal, vol. 8, no. 1, pp. 49-60. 
Tiris, C, Tiris, M and Dincer, I 1996, 'Experiments on a new small-scale solar dryer', Applied Thermal Engineering, vol. 16, no. 2, pp. 183-7.

Tiris, C, Ozbalta, N, Tiris, M and Dincer, I 1995, 'Thermal performance of a new solar air heater', International Communications in Heat and Mass Transfer, vol. 22, no. 3 , pp. $411-23$.

Vlachos, NA, Karapantsios, TD, Balouktsis, AI and Chassapis, D 2002, 'Design and Testing of a New Solar Tray Dryer', Drying Technology, vol. 20, no. 6, pp. 124371. 


\section{GENERATION OF TMY DATA FOR BHUTAN}

\subsection{Introduction}

In general, the long-term performance predictions of any solar energy system depends on the long-term climatic features of a location (Argiriou et al. 1999; Celik 2003; Ecevit et al. 2002; Gansler et al. 1994; Kalogirou 2003; Knight et al. 1991; Skeiker 2004; Zeroual et al. 1996) The need for and advantage of using a one year meteorological data file for evaluating the long-term system performance has led to the development of a Typical Meteorological Year (TMY), a term used in USA, or Test Reference Year (TRY) or Design Reference Year, terms used in Europe (Argiriou et al. 1999; Celik 2003; Ecevit et al. 2002; Satyamurty \& Ravikumar 2004; Skeiker 2004).

Typical Meteorological Year data is a set of hourly values of solar radiation and meteorological elements for a period of one year generated from long-term observed data. Santos et al. (2003) claimed that meteorological variables are highly random for a short period of time like days and nights and highly deterministic for a long period of time like months and years. However, these data sets correspond to the occurrence and persistence of the weather in all months. TMY provides a standard hourly data of solar radiation and other meteorological elements that permit comparison of the performance of different solar energy systems and configurations for various locations. It does not indicate conditions over the next year, rather it represents conditions judged to be typical over a long period of time. Therefore, TMY data may not be suitable for designing systems to meet worst-case conditions occurring at a location.

Different countries have generated TMY data for various locations. However, at the time of this study, Bhutan neither has TMY data readily available nor any attempt has been made to generate TMY data. So, the first step in this study is to generate TMY data for Bhutan. 


\subsection{Methods of TMY data generation}

The literature indicates that there are several methods to generate TMY data. Ecevit et al. (2002) summarised three different methods to generate TMY data. They are

- Danish method by Anderson et al. in 1977 and by Lund and Eidorff in 1981;

- Festa Ratto method in 1993;

- Sandia National Laboratory method by Hall et al. in 1978.

These methods have been explained in detail by Argiriou et al. (1999); Ecevit et al. (2002); Gazela \& Mathioulakis (2001), so this study will not dwell on how each method works. However, these three methods mentioned above require long-term climatic data to generate TMY data for a particular location. Unfortunately, like most developing countries, Bhutan has no meteorological station, so long-term climatic data is not available. Thus, a different approach has to be used to generate TMY data for Bhutan.

Santos et al. (2003) suggested two methods for estimating meteorological variables when long term observed data are not available. The first method is by extrapolating from similar data from location with similar climatic conditions. A significant error has been reported using this method due to variations in climatic conditions. The second method is to generate the data synthetically from a limited set of input data. This method was developed by Knight et al. (1991) and was incorporated into the TRNSYS program (more about TRNSYS is explained in Section 5.5) as Type 54 weather generator.

This component uses monthly average values of solar radiation, dry bulb temperature, humidity ratio and wind speed to generate monthly weather data approximately equal to the TMY data of a location (TRNSYS 2003). This allows TRNSYS to be used for locations where detailed weather data is not available. The methodology used is not pursued in this study since it is well explained in detail by Knight et al. (1991). However, as mentioned by Knight et al. (1991), the method used for generation was developed for temperate climate data and the accuracy of the data generated is unknown for other climate data. 
Although chilli is mainly grown in sub-tropical and warm temperate regions in Bhutan, the region under study is in warm temperate climatic regions. So the Type 54 weather generator can be used for solar simulation without further modifications. However, the Type 54 requires monthly average insolation, ambient temperature, wind speed and humidity ratio as inputs which Bhutan has none. Therefore these data have to be extracted from NASA.

NASA satellite data which gives average values for last ten years (NASA 2004a) has insolation uncertainties up to $17 \%$ (NASA 2004b), so the output from the Type 54 may further vary. Thus output from the Type 54 needs to be verified against known and measured values. In this case the measured value is TMY data. Therefore, output from the Type 54 using inputs from NASA will be compared to TMY data and further verified using average monthly long-term observed data as inputs to the Type 54 .

\subsection{Validation of Type 54 weather generator}

The validation method is described in the following sections and illustrated in Fig 4.1.

\subsubsection{Selection of locations}

As Bhutan has no meteorological station, the Type 54 weather generator output has to be compared for some other location which has both TMY data and long-term average monthly observed meteorological data. However, the climatic features of the selected locations have to be similar to Bhutan's climate so that the same validation is applicable to Bhutan.

Thus, to make a realistic comparison, monthly average temperature and solar radiation were extracted from NASA for Bhutan and several other cities which are located at about the same latitude. From the plot of solar radiation and average temperature of Bhutan and other cities, it was revealed that the regions in the Himalayas like New Delhi, Kathmandu, Lahore and Lhasa exhibited the same pattern of climatic variation to that of Bhutan. However, these cities do not have TMY data and hence cannot be used. 


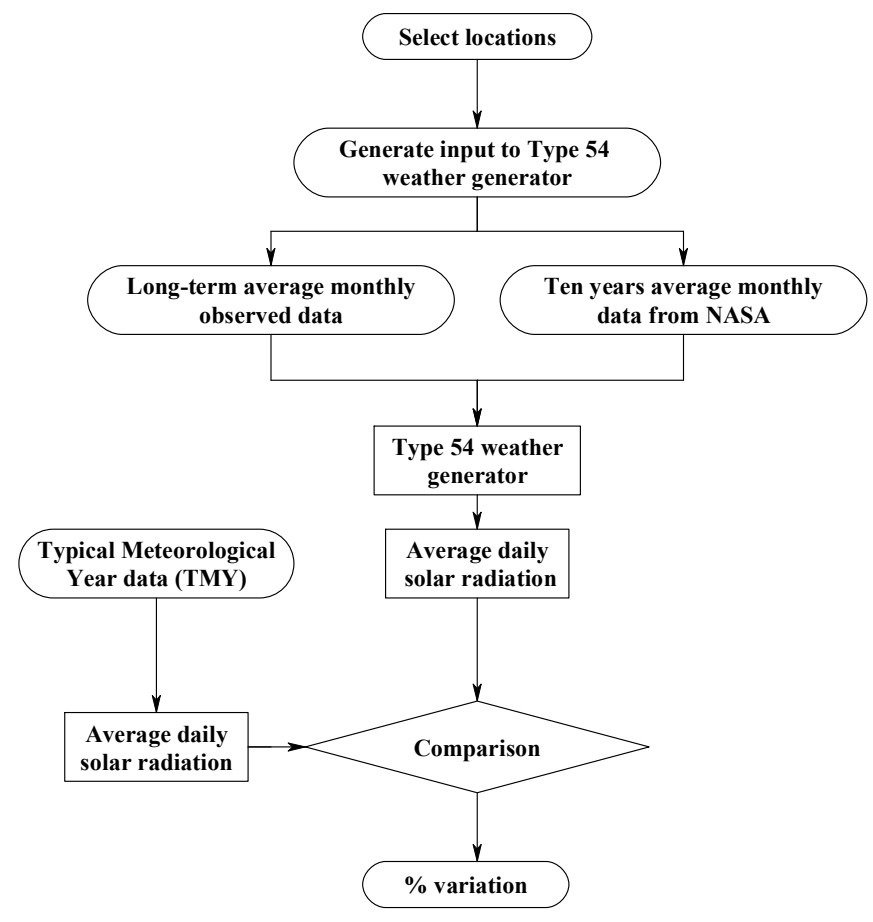

Fig. 4.1. Flowchart for validating Type 54 weather generator

A further search revealed that Canberra, Hobart and Melbourne in Australia are found to be closer to Bhutan in terms of average monthly solar radiation and temperature and these cities do have both TMY data and long-term average monthly observed data for more than 10 years. Thus these three cities were selected as best possible location for validating the Type 54 weather generator. Fig. 4.2 and 4.3 shows the variation of solar radiation and temperature for three Australian cities and Bhutan. Since Bhutan is located in Northern Hemisphere, the $\mathrm{X}$-axis has been adjusted to show the similar season to that of Australia (i.e. for Bhutan X-axis should be read from January, not July).

\subsubsection{Validation inputs}

As indicated in Fig 4.1, two sets of inputs are used for validation. The first set of inputs was taken from average monthly long-term observed (AMLTO) data (Unimelb 1980). The second set of input was extracted from NASA satellite (NASA 2004a) for the same latitude and longitude as the first set (see Appendix $3 \& 4$ for the detailed data set 
used). These two sets of inputs were then used to generate yearly meteorological data from the Type 54 weather generator.

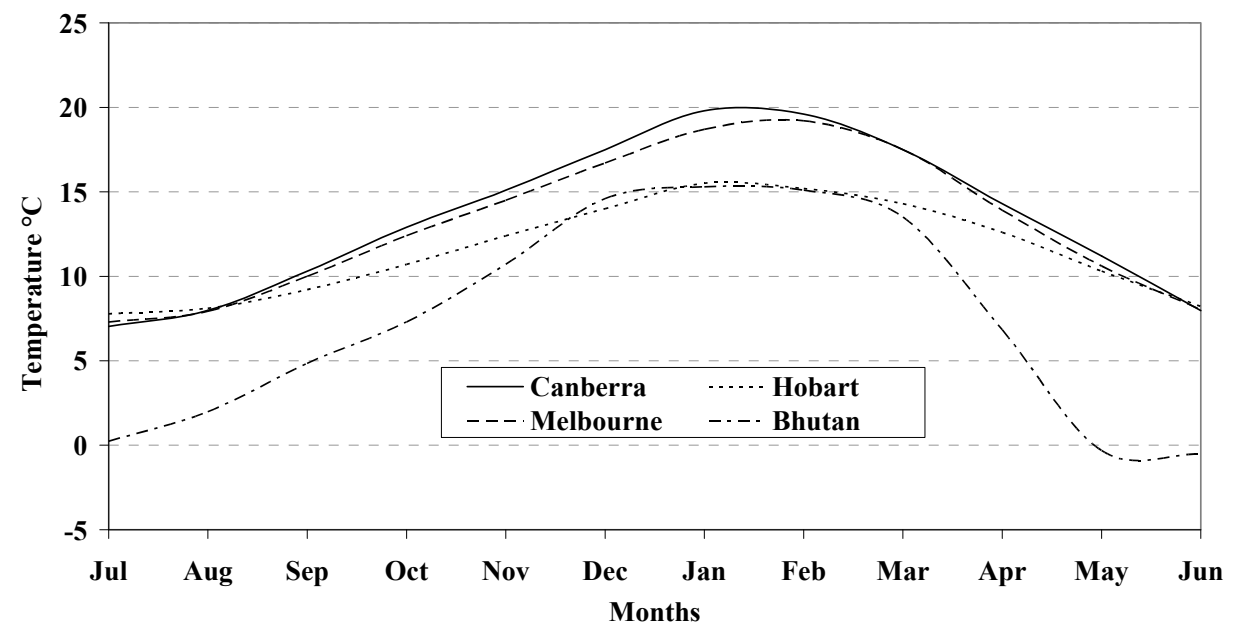

Fig. 4.2. Average monthly temperature

From the generated meteorological data, two sets of average daily solar radiations were extracted for two sets of inputs used. These values were compared with a set of average daily solar radiations extracted from TMY data from Morrison and Litvak (1999). Here TMY data is taken as the best case since TMY represents a typical year selected from long-term observed data and therefore is a universally accepted meteorological data model. Literature also reveals no or minimal variation in system performance using TMY data compared to long-term observed data. The results of the comparison are discussed in following paragraphs.

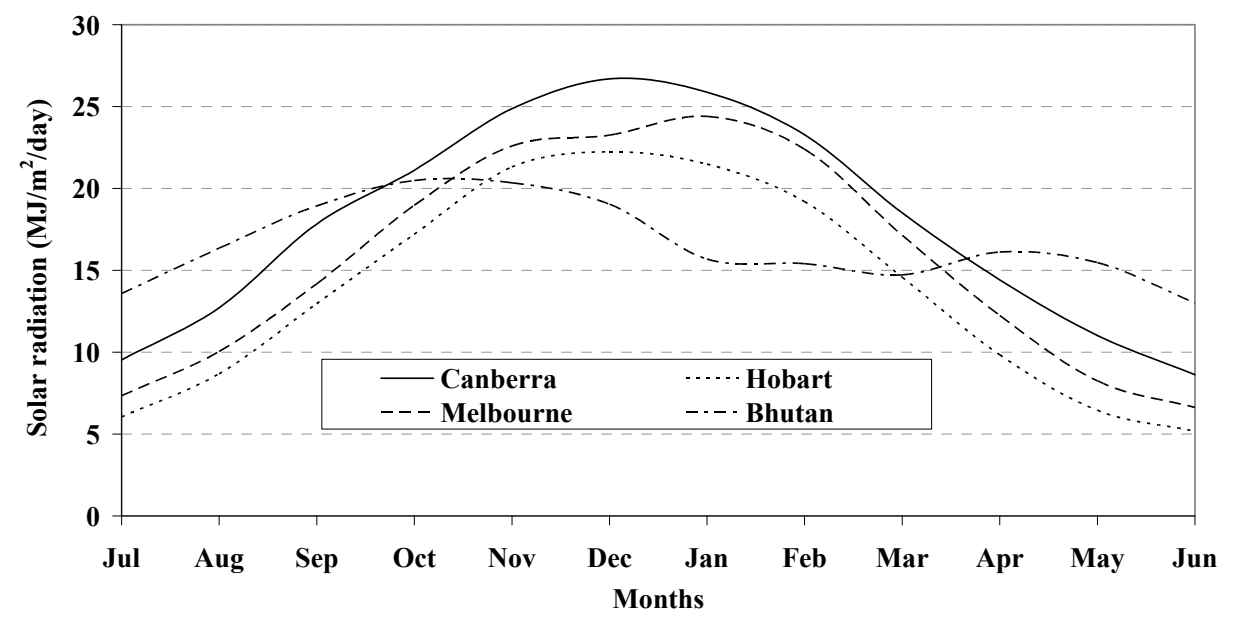

Fig. 4.3. Average monthly solar radiation 


\subsection{Comparative analysis}

Solar radiation is the prime forcing function for any solar energy system (Sukhera et al. 1986). Thus the comparison of the data will be based on the average daily solar radiation. Fig. 4.4 shows the comparison of average daily horizontal surface radiation for three locations; Canberra, Hobart and Melbourne.

Solar radiation for all three different sets of data are close to each other. This is true for all the three locations. In fact, the yearly average solar radiation variation is minimal. Table 4.1 shows the root-mean-square deviation (RMSD) of solar radiation for inputs from NASA and AMLTO expressed as a percentage of solar radiation from TMY data. From the table it is evident that the inputs from NASA show a deficit of $10.8 \%$ for Canberra while it over-estimates for Hobart and Melbourne by $11.7 \%$ and $7.5 \%$ respectively. The inputs from AMLTO show a deficit of 3.2\% for Canberra while it over-estimates for Hobart and Melbourne by $6 \%$ and $6.4 \%$ respectively.

The estimate of solar radiation using the Type 54 with AMLTO data is closest to the TMY data, and the variation is significant (i.e. greater than 10\%) in case of inputs from NASA. The reason for this could be due to the source of the input data. NASA estimated uncertainties (RMS bias) of $18.5 \%$ for relative humidity, $3.2 \%$ for air temperature and 10 to $17 \%$ for horizontal insolation (NASA 2004b) (see Appendix 5 for details). Further it states that the variation could be either positive or negative. As all these quantities are used as inputs to Type 54 weather generator, a variation in prediction may not be ruled out. Thus, appropriate values may need to be accounted for in the design calculations when using inputs from NASA.

Table 4.1: Yearly root-mean-square deviation of solar radiation

\begin{tabular}{lrrc}
\hline \multicolumn{1}{c}{ Inputs } & Canberra & Hobart & Melbourne \\
\hline NASA & $-10.8 \%$ & $11.7 \%$ & $7.5 \%$ \\
AMILTO & $-3.2 \%$ & $6.0 \%$ & $6.4 \%$ \\
\hline
\end{tabular}




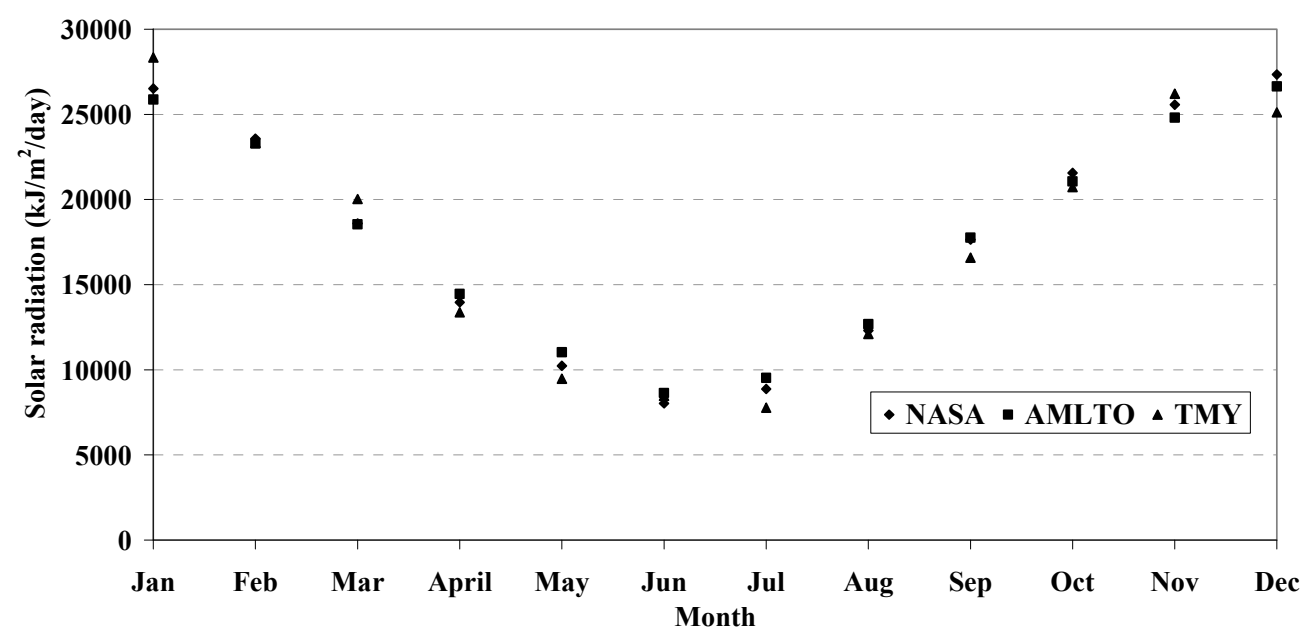

(a)

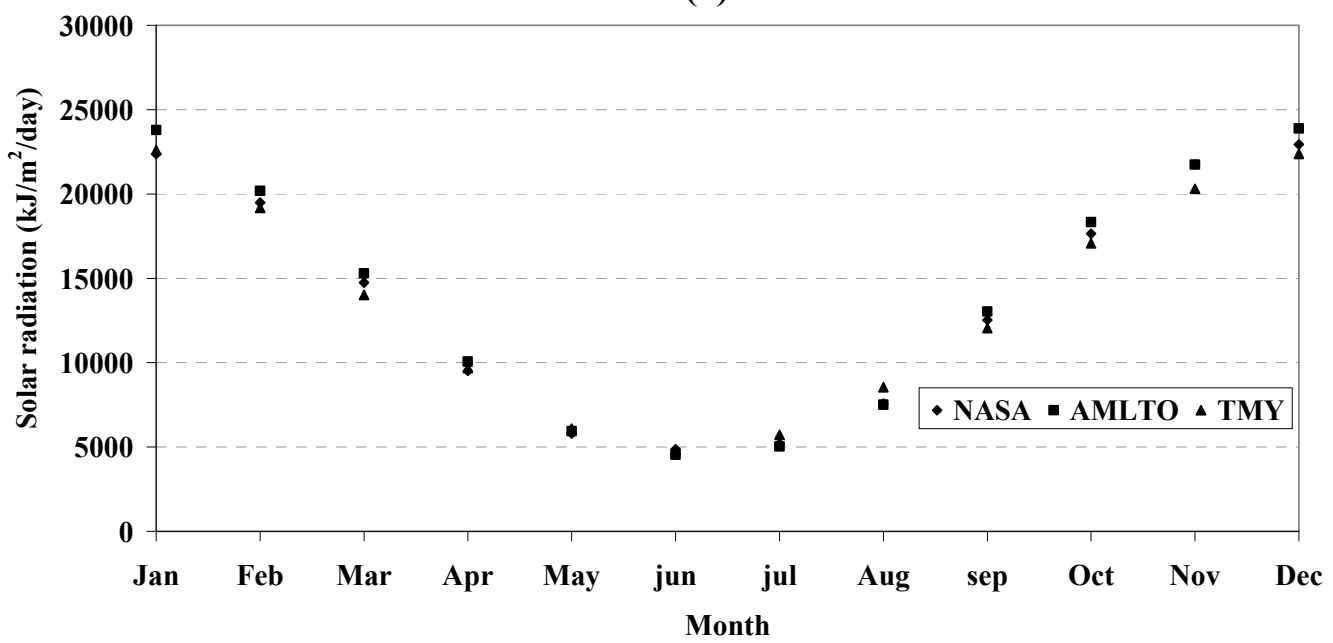

(b)

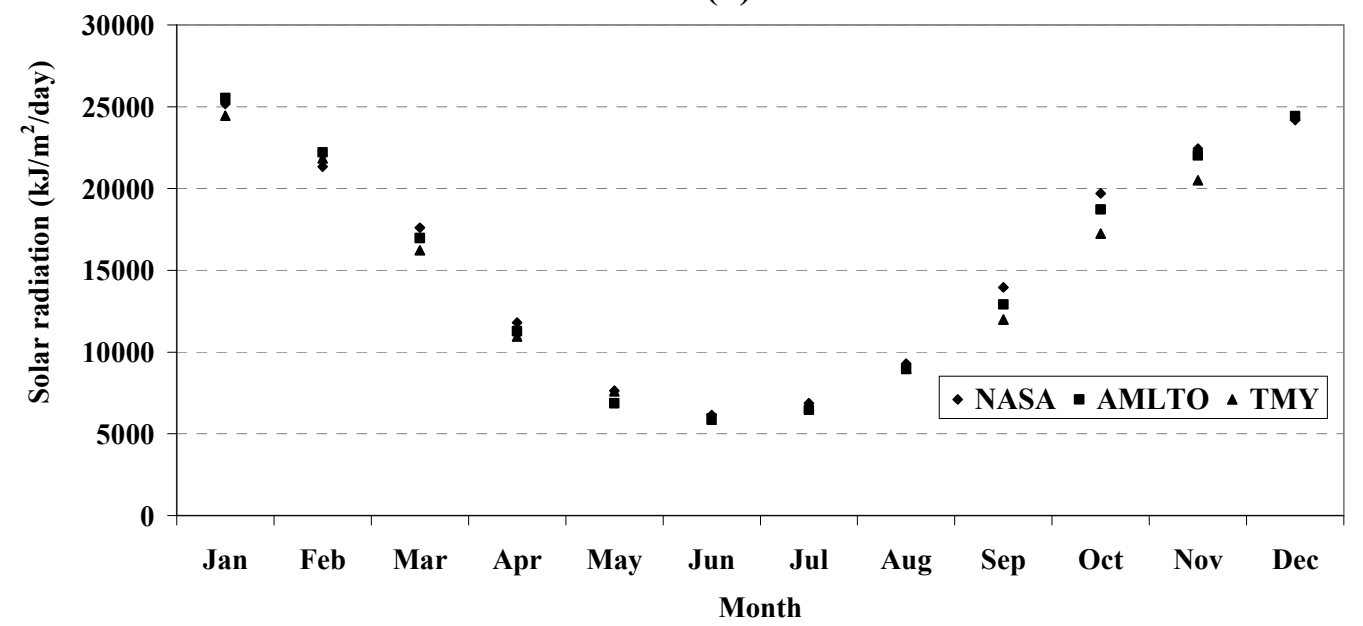

(c)

Fig. 4.4. Comparison of average daily horizontal surface radiation generated using NASA and AMLTO with TMY (a) Canberra (b) Hobart (c) Melbourne 


\subsection{Conclusions}

The Type 54 weather generator can be used for generation of TMY data for locations where meteorological stations are not available. As the accuracy of the Type 54 weather generator using NASA data as inputs was not known, it has been verified for three locations in Australia by comparing the average daily solar radiation generated by Type 54 weather generator using two different sets of inputs against standard TMY data available for a location. From the comparison, it was found that the percentage variation is less than 7\% for inputs from long-term observed data and more than 5\% for inputs from NASA. Thus it indicates that although the Type 54 weather generator can be used for solar simulations without any further modifications, it has to be used with caution when the inputs are from NASA satellite data.

\subsection{References}

Argiriou, A, Lykoudis, S, Kontoyiannidis, S, Balaras, CA, Asimakopoulos, D, Petrakis, M and Kassomenos, P 1999, 'Comparison of methodologies for TMY generation using 20 years data for Athens, Greece', Solar Energy, vol. 66, no. 1, pp. 33-45.

Celik, AN 2003, 'Long-term energy output estimation for photovoltaic energy systems using synthetic solar irradiation data', Energy, vol. 28, no. 5, pp. 479-93.

Ecevit, A, Akinoglu, BG and Aksoy, B 2002, 'Generation of a typical meteorological year using sunshine duration data', Energy, vol. 27, no. 10, pp. 947-54.

Gansler, RA, Klein, SA and Beckman, WA 1994, 'Assessment of the Accuracy of Generated Meteorological Data for Use in Solar-Energy Simulation Studies', Solar Energy, vol. 53, no. 3, pp. 279-87.

Gazela, M and Mathioulakis, E 2001, 'A new method for typical weather data selection to evaluate long-term performance of solar energy systems', Solar Energy, vol. 70, no. 4, pp. 339-48. 
Kalogirou, SA 2003, 'Generation of typical meteorological year (TMY-2) for Nicosia, Cyprus', Renewable Energy, vol. 28, no. 15, pp. 2317-34.

Knight, KM, Klein, SA and Duffie, JA 1991, 'A methodology for the synthesis of hourly weather data', Solar Energy, vol. 46, no. 2, pp. 109-20.

Morrison, GL and Litvak, A 1999, Condensed Solar Radiation Data Base for Australia, 1/1999, Solar Thermal Energy Laboratory, University of New South Wales, Sydney, Australia.

NASA 2004a, NASA Surface Meteorology and Solar Energy: Global/regional data, $<$ http://eosweb.larc.nasa.gov/cgi-bin/sse/sse.cgi?na+s01\#s01>.

NASA 2004b, NASA Surface Meteorology and Solar Energy: Accuracy, $<$ http://eosweb.larc.nasa.gov/cgi-bin/sse/sse.cgi?na+s05\#s05>.

Santos, JM, Pinazo, JM and Canada, J 2003, 'Methodology for generating daily clearness index values K-t starting from the monthly average daily value (K)over-bar(t). Determining the daily sequence using stochastic models', Renewable Energy, vol. 28, no. 10, pp. 1523-44.

Satyamurty, VV and Ravikumar, P 2004, 'Generation of hourly ambient temperature from generalised cumulative frequency distributions', Journal of Solar Energy Engineering-Transactions of the Asme, vol. 126, no. 2, pp. 683-95.

Skeiker, K 2004, 'Generation of a typical meteorological year for Damascus zone using the Filkenstein-Schafer statistical method', Energy Conversion and Management, vol. 45, no. 1, pp. 99-112.

Sukhera, MB, Pasha, MAR and Naveed, MS 1986, 'Solar radiation over Pakistan-comparison of measured and predicted data', Solar \& Wind Technology, vol. 3, no. 3, pp. 219-21. 
TRNSYS 2003, A TRaNsient SYstems Simulation program, University of Wisconsin, Wisconsin, USA.

Unimelb 1980, Theory and Design of Solar Thermal Systems, Mechanical Engineering Department, The University of Melbourne, Melbourne, Australia.

Zeroual, A, Ankrim, M and Wilkinson, AJ 1996, 'The diffuse-global correlation: Its application to estimating solar radiation on tilted surfaces in Marrakesh, Morocco', Renewable Energy, vol. 7, no. 1, pp. 1-13. 


\section{PERFORMANCE EVALUATION OF THE EXISTING SOLAR DRYER AT KHAO-KOR}

\subsection{Introduction}

As stated in Section 1.4.2, the objective of this study is to evaluate a suitable solar dryer for drying agricultural products in Bhutan. The solar dryer should be financially and practically viable. To achieve these objectives, an existing commercial solar dryer installed at Khao-kor in Thailand (latitude $16.42^{\circ} \mathrm{N}$ and altitude $166 \mathrm{~m}$ above sea level) was selected. The selection was based on the following criteria:

- The existing solar dryer was successfully installed;

- The dryer was tested for varieties of products like basil, banana, turmeric, ginger, cabbage and chilli;

- The dryer is simple to operate.

Although the solar dryer installed at Khao-kor in Thailand has been successfully implemented, the same performance level may not be anticipated in Bhutan. This is largely due to the variations in the operating conditions particularly climate and quality interpretation (dryness) and the economic considerations.

Fig 5.1 shows the average annual solar radiation and ambient air temperature in Bhutan and Khao-kor. While Khao-kor is associated with high ambient air temperature and moderate solar radiation, Bhutan receives higher solar radiation but the ambient air temperature is much lower. The ambient temperature in Bhutan varies from -5 to $15^{\circ} \mathrm{C}$ whereas in Khao-kor the ambient temperature ranges from $20-28^{\circ} \mathrm{C}$. While Khao-kor is in a tropical climatic region, the dryer in Bhutan is envisaged to be used in warm temperate and sub-tropical climatic regions. Thus a comprehensive evaluation is necessary to determine the technical and financial viability before replicating the Khao-kor type solar dryer in Bhutan. 


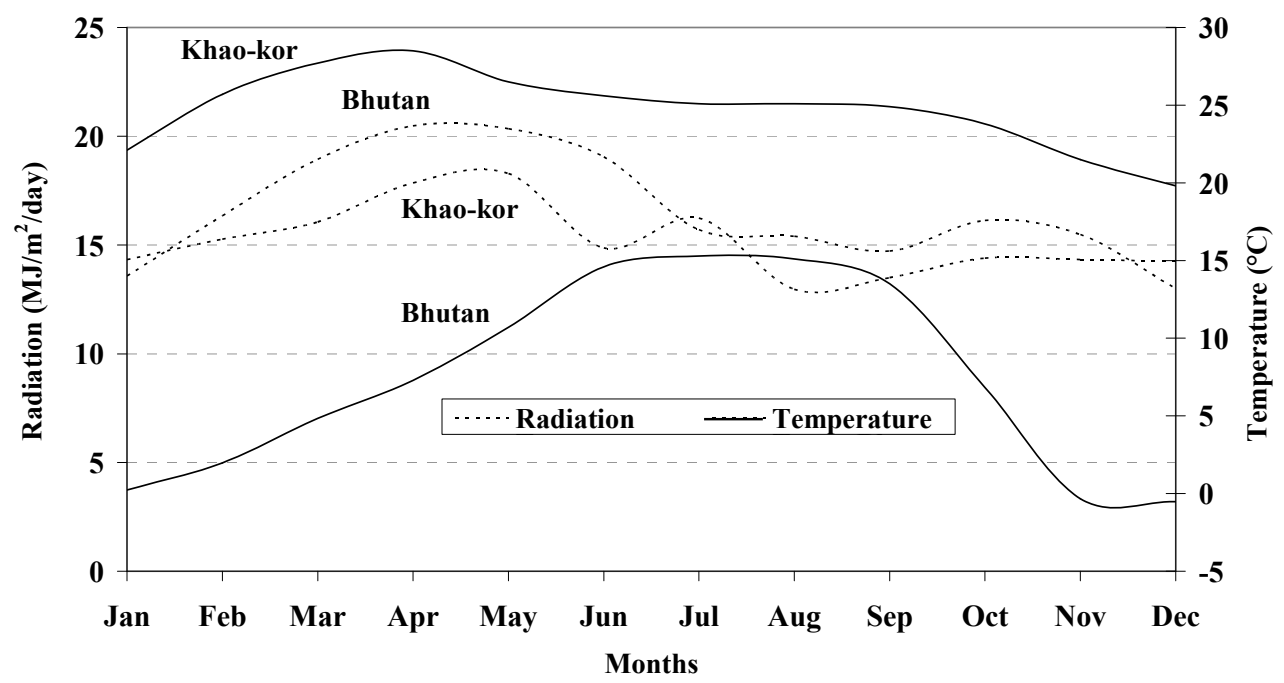

Fig. 5.1. Comparison of radiation and ambient temperature in Bhutan and Khao-kor (NASA 2004)

\subsection{Performance evaluation by simulation}

Simulation is a design tool which can be used repeatedly for evaluating the performance of the system with different design parameters. Development of a simulation model is considered as a valuable tool for predicting the performance of solar cop dryers in various locations (El-Sebaii et al. 2002). Simulations can be performed to subject the system to extreme weather conditions and loads. Solar energy being highly transient, a theoretical model is a helpful and a necessary tool for researchers. Simulation provides an opportunity to assess alternatives and avoids full scale experimentation which is very expensive. A reliable model may prevent mistakes in development of a prototype.

Fuller et al. (1999) modeled the existing solar crop dryer in Thailand using the solar simulation software, TRNSYS (TRNSYS is described in Section 5.5) and the results of the simulation were found similar to the measured values. However, only six hours of data was used. Also Reuss and Benkert (1995) modeled a solar wood dryer using TRNSYS. The model was experimentally investigated at the same time. The observed differences were found within the expected range. Thus, in this study TRNSYS is used to evaluate the performance of the solar dryer system. 


\subsection{Parameters of performance evaluation}

A search of literature revealed different methods to report solar dryer performance results. Grupp et al. (1995 in Leon et al. 2002) proposed a test from the users perspective and the parameters reported were the physical dimensions, type of dryer, solar aperture, tray area, drying time, drying temperature, final moisture content, dried product quality and ease of handling. Sodha and Chandra (1994) argued that in addition to the above parameters, cost, lifetime durability and maintenance requirements should be considered. Leon et al. (2002) reviewed different solar dryer evaluation parameters used in the literature (reproduced in Appendix 6). It is evident that different authors have used different parameters to evaluate solar dryers and no consistent method is available. Leon et al. (2002) compiled a set of parameters to report the solar dryer performance results, as listed below.

\section{i. Physical features}

- Type of dryer

- Size and shape of dryer

- Collector area and solar aperture

- Drying capacity, drying bed area and ease of loading and unloading

\section{ii. Thermal performance}

- Drying time/drying rate

- Drying temperature

- Relative humidity

- Air flow rate

- Dryer efficiency

\section{iii. Quality of dried product}

- Sensory quality (colour, flavour, taste, texture and aroma)

- Nutritional attributes

- Rehydration capacity

\section{iv. Financial viability}

- Cost of dryer and drying

- Payback period 
The physical features of the dryer investigated in this study are assumed to be same as already installed in Khao-kor. The evaluation of the quality of dried product is beyond the scope of this study. Thus this study focuses only on the thermal performance and financial viability of Khao-kor type solar dryer replicated in Bhutan. Depending on the results of performance evaluation, the physical features may or may not need alteration.

\subsection{Thermal performance evaluation}

\subsubsection{Physical features of solar dryer in Khao-kor}

The solar drying system in Khao-kor consists of four batch type drying units. Each unit has a $73 \mathrm{~m}^{2}$ collector area, $2 \mathrm{~kW}$ blower, $2.75 \mathrm{~m}^{2}$ drying bed, air to steam heat exchanger and rectangular ducts (Fuller et al. 1999; Swasdisevi et al. 1999). Swasdisevi et al. (1999) tested the dryer system experimentally while Fuller et al. (1999) modeled the solar dryer system and the simulation results were found similar with maximum variation of 5\%. Table 5.1 summarises the parameters of the existing solar dryer at Khao-kor.

Table 5.1. Parameters of existing dryer at Khao-kor

\begin{tabular}{llr}
\hline \multicolumn{1}{c}{ Parameters } & \multicolumn{1}{c}{ Unit } & Value \\
\hline Capacity of dryer & $\mathrm{kg}$ & $100-150$ \\
Collector area & $\mathrm{m}^{2}$ & 73 \\
Mass flow rate of air & $\mathrm{kg} / \mathrm{hr}$ & 3120 \\
Velocity of air & $\mathrm{m} / \mathrm{s}$ & 0.75 \\
Drying air temperature & ${ }^{\circ} \mathrm{C}$ & 60 \\
Drying bed area & $\mathrm{m}^{2}$ & 2.75 \\
\hline
\end{tabular}

Fig. 5.2 shows a schematic diagram of solar dryer at Khao-kor. The system has a blackened solar heat absorber that has a transparent cover and is well insulated on its lower side. As the air is sucked in through the collector, it is heated up by the heat generated due to solar energy absorbed by the collector. Further it is heated up by the steam to air heat exchanger if the air temperature was lower than the set value of $60^{\circ} \mathrm{C}$. The heated air is then blown into the drying trough. 
1. Inlet air

2. Solar collector

3. Outlet air from collector

4. Blower

5. Heat exchanger

6. Drying cabinet

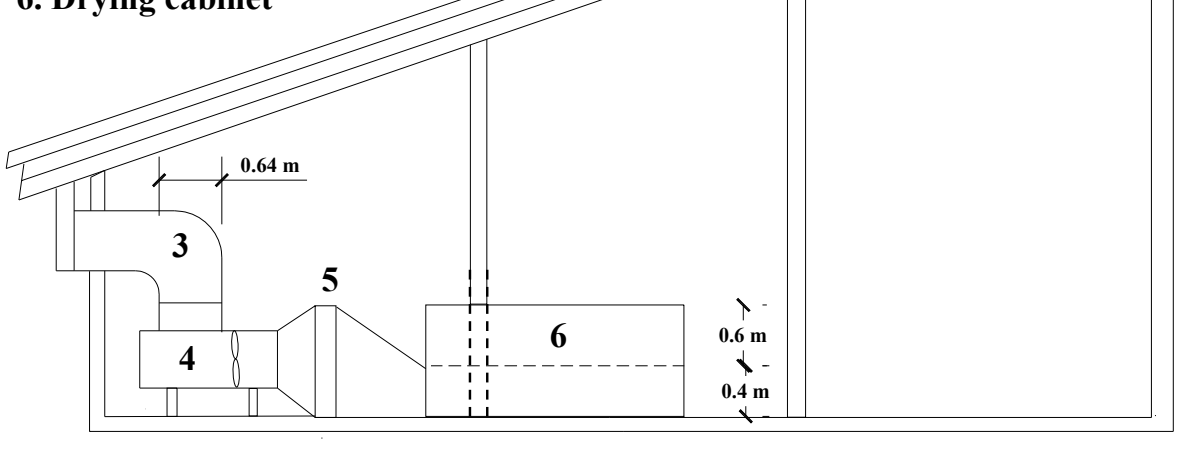

2
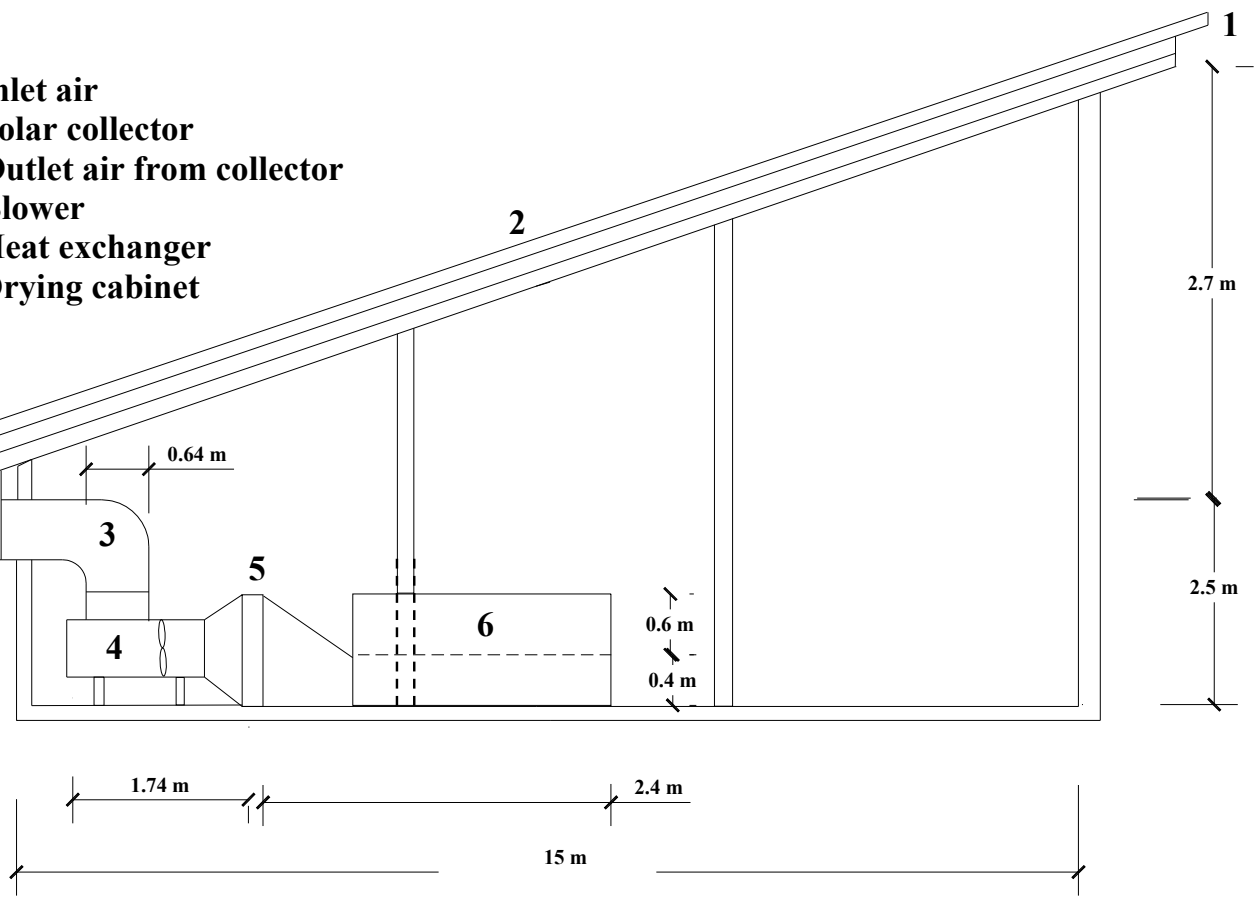

Fig. 5.2. Schematic diagram of solar dryer at Khao-kor

\subsubsection{Drying periods}

The drying periods of products are dependent on their availability during the year.

While the chilli harvest is limited to two months a year, beef is available throughout the year and therefore can be dried any time. However, the drying period has to be chosen to maximise the use of solar energy.

\section{a) Chilli drying}

As chilli is harvested during the months of August and September, it is intended that the dryer will be used exclusively for drying chilli during these two months. The dryer will be simulated during these two months for chilli using the TMY data generated in Section 4. The average solar radiation during this period is $15.28 \mathrm{MJ} / \mathrm{m}^{2} /$ day. The time of drying is chosen to maximise utilisation of the solar energy available and minimise use of the auxiliary energy. Fig. 5.3 shows the average hourly global solar radiation during the months of August and September. The solar radiation is highest during the period 10 a.m - 5 p.m. However to select the best possible drying period, the time 
taken to reduce the moisture content from $567 \%(\mathrm{db})$ to $10 \%(\mathrm{db})$ has to be determined. Thus, for the first drying cycle the dryer will start at $10 \mathrm{a} . \mathrm{m}$ and continue until the final moisture content of chilli is less than $10 \%(\mathrm{db})$ to determine the drying time. The subsequent drying cycle will be based on the required drying time, as determined from the first drying cycle.

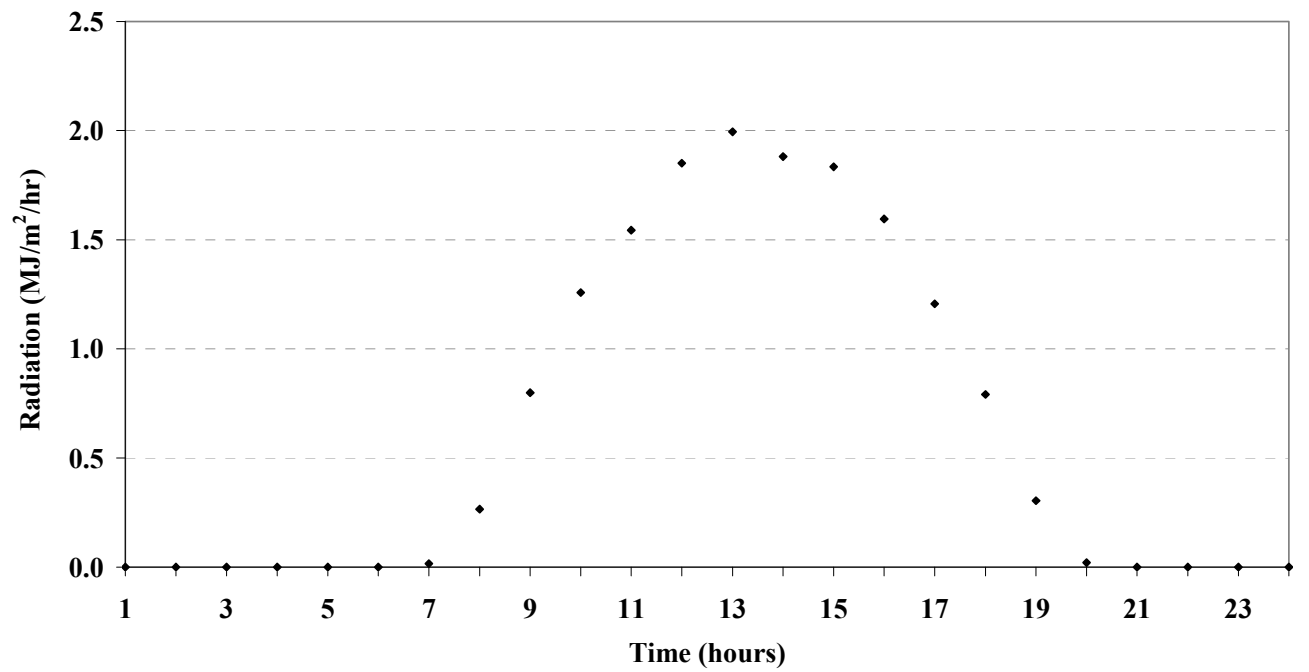

Fig. 5.3. Average hourly solar radiation during the period August to September

\section{b) Beef drying}

As there is no particular season for drying meat, it can be dried on any day during the periods January to July and October to December. However, as per the Livestock Act of Bhutan (Dorji 2004b), slaughtering of animals and sale of meat in Bhutan is banned during the first and fourth months of Bhutan's Lunar calendar. The first month of the Lunar calendar in Bhutan falls on $15^{\text {th }}$ February $-16^{\text {th }}$ March and the fourth month falls from $17^{\text {th }}$ May $-15^{\text {th }}$ June. Thus during these two periods, meat cannot be dried. This indicates that although solar radiation is highest between March and June, this period cannot be fully utilised for drying meat due to the slaughter ban. Thus, meat can be dried during the periods $1^{\text {st }}$ January to $14^{\text {th }}$ of Feb, $17^{\text {th }}$ March to $16^{\text {th }}$ May, $16^{\text {th }}$ June to $31^{\text {st }}$ July and from October to December. 


\subsubsection{Batch size}

\section{a) Chilli}

The quantity of chilli that could be dried per batch is assumed to be equal to the maximum capacity of the dryer i.e. $150 \mathrm{~kg} / \mathrm{batch}$. The chilli will be dried in thin layers without slicing or any other treatment before drying.

\section{c) Beef}

Since the principle product in this study is chilli, the same dryer parameters obtained for chilli will be used for drying beef. However, unlike chilli which is dried in layers, beef cannot be dried in layers as the air flow will be blocked and moreover, the surface in contact cannot be dried. Thus beef has to be dried by hanging with hooks over wires fixed on the surface of the dryer trough. Therefore, the quantity of beef that could be dried per batch is $100 \mathrm{~kg} / \mathrm{batch}$ from Appendix 7 .

\subsubsection{Supplementary energy source}

Since hydropower is the main source of energy in Bhutan, the use of any other energy sources is likely to be very expensive and may not be affordable to the rural people. Thus electricity is proposed as the supplementary energy source.

\subsubsection{Inclination of the solar collector}

Generally, the solar radiation absorbed by the surface depends on the angle of incidence which is the angle between the sun's rays and a line normal to the surface of the collector. This angle varies with the time of the year. Thus the inclination of collector depends on the drying season. For winter drying, latitude plus $10^{\circ}-15^{\circ}$ gives the maximum solar energy available to the collector surface while latitude minus $10^{\circ}$ $15^{\circ}$ gives maximum solar energy for the summer loads (Howell et al. 1982 p. 237). For year-round drying, a collector slope equal to the latitude angle gives the maximum solar energy to the collector surface (AIT 2004; Anderson 1983; Howell et al. 1982; USDA 1980). Thus a slope of $28^{\circ}$ equal to the latitude angle of the location under study is used. 


\subsection{System model}

The complete solar drying system has been modeled using TRNSYS (version 15.3). TRNSYS - Transient Simulation Programme is based on a modular approach where each module is a separate entity. The TRNSYS library includes the most common components used in a solar thermal energy system, modules to handle weather and output data. Each module can operate in several different modes. TRNSYS has the capability of interconnecting the system components in any desired manner. Moreover, any module can be easily added to the library without any further modifications. These features, i.e. adaptability and flexibility, make TRNSYS a comprehensive package to simulate solar thermal energy systems.

In this study, standard components were used from the TRNSYS library and functions of the components used in this study are explained in Appendix 8. The drying trough model which is not available in the TRNSYS library has been written separately using FORTRAN codes and exported to TRNSYS library using Compaq Visual Fortran and named as a Type 104. The subroutine is based on the mathematical expressions described in the next sections. This component computes the collector efficiency, system efficiency, pick-up efficiency, final moisture content and equilibrium moisture content. The source code of the subroutine is given in Appendix 9.

\subsection{Modeling of dryer trough}

\subsubsection{Drying Rate}

As reported in Section 2.3, drying rate for thin bed drying is based on Newton's law of cooling and is proportional to the difference between actual and equilibrium moisture contents (Equation 5.1) (Ekechukwu 1999; Erenturk et al. 2004; Hall 1957, 1980; Telis et al. 2004).

$$
\begin{aligned}
\frac{\left(M-M_{e}\right)}{M_{o}-M_{e}} & =e^{-k t} \\
\text { where } M & =\quad \text { Moisture content of sample }(\mathrm{db}) \\
M_{e} & =\quad \text { Dynamic equilibrium moisture content }(\mathrm{db})
\end{aligned}
$$




$$
\begin{array}{lll}
M_{o} & = & \text { Initial moisture content of sample }(\mathrm{db}) \\
k & = & \text { Drying constant }\left(\mathrm{min}^{-1)}\right. \\
t & = & \text { Drying time }(\mathrm{min})
\end{array}
$$

The drying constant ' $k$ ' is determined by experimental studies of moisture removal at different drying conditions. It is dependent on crop and drying air properties.

\subsubsection{Equilibrium moisture content}

The equilibrium moisture content of chilli is computed using the equation proposed by Kaleemullah (2002 in Kaleemullah \& Kailappan 2004) (Equation 5.2). Kaleemullah and Kailappan (2004) studied the moisture sorption isotherms of red chllies using several equations i.e. Oswin (1946), Smith (1947), Halsey (1948), Henderson (1952), Day and Nelson (1965), modified Henderson (1968), modified Halsey (1976) and Kaleemullah (2002). It was found that the Kaleemullah equation (2002) best described the sorption isotherms of chillies.

$$
M e(d b)=\left[\frac{\ln \{(R h-a) /(-b)\}}{-\left(c \times T_{c}\right)}\right]^{(1 / d)}
$$

where $R h \quad=\quad$ Relative humidity (decimal)

$$
\begin{array}{lll}
T_{c} & = & \text { Temperature }\left({ }^{\circ} \mathrm{C}\right) \\
a, b, c, d & = & \text { Dimensionless constants }
\end{array}
$$

The values of constants $a, b, c$, and $d$ as obtained by Kaleemullah and Kaillapan (2004) were used in this study to compute the equilibrium moisture content of chillies. They are:

$$
\begin{array}{lll}
a=0.8406 ; & b=0.8189 \\
c=0.000739 ; & d=1.4102
\end{array}
$$

\subsubsection{Dryer efficiency}

The efficiency of a solar dryer is studied under three contexts: heat collection efficiency which is normally called as collector efficiency, system efficiency and pickup efficiency. 


\section{a) Collector efficiency}

The collector efficiency is the measure of collector performance in the dryer system. It measures how effectively the solar radiation incident on the collector area is transferred to the drying air flowing through it. This can be computed using the Equation 5.3 (AIT 2004; Leon et al. 2002)

$$
\eta_{c} \quad=\quad \frac{m \times C_{p} \times\left(T_{o}-T_{i}\right)}{I \times A_{c}}
$$

where $m \quad$ = Mass flow rate of air through collector $(\mathrm{kg} / \mathrm{hr})$

$C_{p} \quad=$ Specific heat of air $\left(\mathrm{kJ} / \mathrm{kg} /{ }^{\circ} \mathrm{C}\right)$

$T_{i}, T_{o}=$ Inlet and outlet temperature of air $\left({ }^{\circ} \mathrm{C}\right)$

$I \quad=$ Average solar radiation $\left(\mathrm{kJ} / \mathrm{m}^{2} / \mathrm{hr}\right)$

$A_{c} \quad=$ Collector area $\left(\mathrm{m}^{2}\right)$

\section{b) System efficiency}

The system efficiency is the measure of how effectively the input energy to the dryer system is used to dry the product. It can be computed by Equation 5.4 (AIT 2004; Leon et al. 2002).

$$
\eta_{s} \quad=\quad \frac{M_{w} \times L}{\left(I \times A_{c}\right)+P_{b}+E_{s}}
$$

where $M_{w} \quad=\quad$ Weight of water removed $(\mathrm{kg})$

$L=\quad$ Latent heat of vaporisation of the product $(\mathrm{kJ} / \mathrm{kg})$

$I=$ Average solar radiation $\left(\mathrm{kJ} / \mathrm{m}^{2}\right)$

$A_{c}=$ Collector area $\left(\mathrm{m}^{2}\right)$

$P_{b} \quad=\quad$ Energy consumption of blower or fan $(\mathrm{kJ})$

$E_{s} \quad=\quad$ Supplementary energy consumption $(\mathrm{kJ})$

\section{c) Pick-up efficiency}

The pick-up efficiency is the ratio of moisture removed from the product by the air flowing through the drying trough to the maximum capacity of the air to absorb 
moisture. The pick-up efficiency can be calculated by Equation 5.5 (AIT 2004; Leon et al. 2002).

$$
\eta_{p} \quad=\quad \frac{W_{o}-W_{i}}{W_{s}-W_{i}}
$$

where $W_{o}=$ Absolute humidity of air leaving the drying trough (decimal)

$W_{i} \quad=\quad$ Absolute humidity of air entering the drying trough (decimal)

$W_{s} \quad=\quad$ Adiabatic saturation humidity of air entering the drying trough (decimal)

\subsection{Financial evaluation}

Economic and financial analysis is necessary for any long term project to determine the viability of a project in terms of its benefit to the investors and as well as to the society as a whole (Finnerty 1996). While financial analysis deals with the net return of the project in terms of monetary values, economic analysis deals with the benefits of the project to the society as a whole. Generally for government projects, both economic and financial analysis are undertaken while the private investors look at only the financial benefits (Yahmadi 2003).

The indices used for financial analysis of solar crop dryers are the cost of the dryer (fixed cost), the cost of drying (variable cost) and the payback period (Leon et al. 2002), however, these three indices do not take into account the time value of money which states that a dollar now is worth more than a dollar promised at some other time in the future. Thus an alternative approach is to use the discounted cash flow technique. The discounted cash flow analysis is a technique by which the future value of money is converted into present value by using the discount rate of a country, which is computed based on the interest and inflation rate of a country. This technique gives a more accurate result compared to the non-discounted technique. Therefore the discounted cash flow technique is used in this study to evaluate the financial viability.

\subsubsection{Financial analysis parameters}


The parameters of a financial analysis include discount rate, inflation rate, project life time and funding sources.

\section{a) Discount rate}

The real discount rate was calculated using the consumer price index in Bhutan (Appendix 10). From the calculation, the approximate real discount rate for Bhutan is $13 \%$ based on 2004 estimate.

\section{b) Inflation rate}

The inflation rate for Bhutan as estimated by National Bureau of Statistics of Bhutan based on the base year 2003 is 5\% (Dorji 2004a). This is assumed to remain constant over the project life time.

\section{c) Project life time}

In this study project life time is assumed as fifteen years based on the life time of timber used for construction.

\subsubsection{Discounted cash flow analysis}

The discounted cash flow analysis involves computation of net present values (NPV), internal rate of return (IRR), benefit cost ratio (BCR) and simple payback period. Each of these are discussed in the following paragraphs.

\section{a) Net present value}

The net present value (NPV) is the difference between discounted benefits and the discounted total capital and operating costs of the system. From the NPV, investors can know whether the project is worth the investment before actually implementing the project. The projects with a positive NPV are considered to be financially viable while for a negative NPV, an alternative to the project should be investigated. The NPV can be computed using the Equation 5.6 (Rocklife 2004). 


$$
N P V=\frac{R \times\left[(1+i)^{t}-1\right]}{i \times(1+i)^{t}}-\frac{-S}{(1+i)^{t}}-C_{c}-\frac{O_{c} \times\left[(1+i)^{t}-1\right]}{i \times(1+i)^{t}}
$$

$$
\begin{array}{cll}
\text { where } R & = & \text { Revenue (US \$/year) } \\
S & = & \text { Residual value (US \$) } \\
C_{c} & = & \text { Capital cost (US \$) } \\
O_{c} & = & \text { Operating cost (US \$/year) } \\
t & = & \text { Project life time (years) } \\
i & = & \text { Real discount rate (decimal) }
\end{array}
$$

\section{b) Internal rate of return}

The internal rate of return (IRR) of a period is the most commonly used assessment criterion in project evaluation because it is comparable to the profit rate of a project. The IRR is the discount rate that makes net present value of cash flow equal to zero. Thus, IRR is the discount rate at which the NPV is zero

\section{c) Benefit-cost ratio}

The benefit-cost ratio (BCR) is the ratio of the sum of the project's discounted benefits to the sum of its discounted capital and operating costs. The BCR estimates the cost effectiveness of a proposed project. The project is considered cost effective if the BCR is greater than one. The BCR can be computed by Equation 5.7 (Rocklife 2004).

$$
B C R=\left\{\frac{R \times\left[(1+i)^{t}-1\right]}{i \times(1+i)^{t}}\right\} /\left\{\frac{O_{c} \times\left[(1+i)^{t}-1\right]}{i \times(1+i)^{t}}+\frac{-S}{(1+i)^{t}}+C_{c}\right\}
$$

\subsubsection{Payback period}

Payback period is also another index used in solar system economic analysis (Kreider et al. 1989). Simple payback period is the technique to compute the total number of years required to pay back the investments from the net benefits. This could be 
computed by dividing the initial investment by annual savings after tax (Thumann 1984; Thumann \& Mehta 1997). Although simple payback is easily understood, it does not take into account the effect of inflation and interest. Thus, this method should be used in conjunction with other decision making tools like net present value and internal rate of return. However, discounted payback period includes the time value of money and hence is more accurate as compared to the simple payback period (Ruegg \& Short 1988).

\subsection{Conclusions}

The method and the parameters used for evaluating the performance of the existing solar dryer at Khao-kor have been explained in the preceding sections. Although there are four different categories of performance evaluation of solar dryers, only technical and financial evaluation have been used in this study. The complete dryer system has been modeled using TRNSYS and simulations were performed for chilli and beef using the TMY data generated in Section 4. The next section describes in detail the simulation results of the technical and financial feasibility of the Khao-kor type solar dryer in Bhutan.

\subsection{References}

AIT 2004, Lecture Notes: Solar Energy, Asian Institute of Technology, viewed 25 September 2004, < $\underline{\text { http://www.courses.ait.ac.th/ED06.22/course1/lecs/>. }}$

Anderson, EE 1983, Fundamentals of Solar Energy Conversion, Addison-Wesley Publishing Company, Menlo Park, California, USA.

Dorji, T 2004a, 'Rising cost of living', Kuenselonline, Bhutan's daily news site, 8 November 2004.

Dorji, T 2004b, 'Nu 135.5 million spent on meat in 2002', Kuenselonline, Bhutan's daily news site, 30 May 2004. 
Ekechukwu, OV 1999, 'Review of solar-energy drying systems I: an overview of drying principles and theory', Energy Conversion and Management, vol. 40, no. 6, pp. 593-613.

El-Sebaii, AA, Aboul-Enein, S, Ramadan, MRI and El-Gohary, HG 2002, 'Empirical correlations for drying kinetics of some fruits and vegetables', Energy, vol. 27, no. 9 , pp. 845-59.

Erenturk, S, Gulaboglu, MS and Gultekin, S 2004, 'The Thin Layer Drying Characteristics of Rosehip', Biosystems Engineering, vol. 6, no. 2, pp. 1-8.

Finnerty, JD 1996, Project Financing: Asset-Based Financial Engineering, John Wiley and Sons Inc., New York, USA.

Fuller, R, Rakwichian, W and Soponronnrit, S 1999, 'Modelling of a Large Solar Drying System in Thailand', paper presented to World Renewable Energy Congress, Perth, Australia, 10-13 February 1999.

Hall, CW 1957, Drying Farm Crops, Agricultural Consulting Associates, Inc., Engineering Specialists, Reynoldsburg, Ohio, USA.

Hall, CW 1980, Drying and Storage of Agricultural Crops, AVI Publishing Company, Inc., Westport, Connecticut, USA.

Howell, JR, Bannerot, RB and Vliet, GC 1982, Solar-Thermal Energy Systems: Analysis and Design, McGraw-Hill Book Company, New York, USA.

Kaleemullah, S and Kailappan, R 2004, 'Moisture Sorption Isotherms of Red Chillies', Biosystems Engineering, vol. 88, no. 1, pp. 95-104. 
Kreider, JF, Hoogendoorn, CJ and Kreith, F 1989, Solar Design: Components, Systems, Economics, Hemisphere Publishing Corporation, New York, USA.

Leon, MA, Kumar, S and Bhattacharya, SC 2002, 'A comprehensive procedure for performance evaluation of solar food dryers', Renewable and Sustainable Energy Reviews, vol. 6, no. 4, pp. 367-93.

NASA 2004, NASA Surface Meteorology and Solar Energy: Global/regional data, $<$ http://eosweb.larc.nasa.gov/cgi-bin/sse/sse.cgi?na $+\mathrm{s} 01 \#_{\mathrm{s} 01>}$.

Reuss, M and Benkert, S 1995, 'Modelling and Experimental Investigation of a Pilot Plant for Solar Wood Drying.' paper presented to 'Solar World Congress 1995', Harare, Zimbabwe, September 9-10, 1995.

Rocklife, N 2004, Project Evaluation, Lecture Notes of Technology Assessment Subject, IDTC - Civil and Environmental Engineering, Engineering Faculty, The University of Melbourne.

Ruegg, RT and Short, W 1988, 'Economic Methods', in E West \& F Kreith (eds), Economic Analysis of Solar Thermal Energy Systems, Massachusetts Institute of Technology, Cambridge, Massachusetts, London, England.

Sodha, MS and Chandra, R 1994, 'Solar drying systems and their testing procedures: A review', Energy Conversion and Management, vol. 35, no. 3, pp. 219-67.

Swasdisevi, T, Soponronnarit, S, Rakwichian, W and Thadnium, V 1999, 'IndustrialScale Solar Vegetable Drying', paper presented to World Renewable Energy Congress, Murdoch University, Western Australia, 10-13 February 1999,.

Telis, VRN, Lourencon, VA, Santos, EM, Borin, I, Gabas, AL and Romero, JT 2004, 'Drying rates of rubi grapes as affected by non-conventional chemical pre- 
treatments', paper presented to 14th International Drying Symposium (IDS 2004), Sao Paulo, Brazil, 22-25 August 2004.

Thumann, A 1984, Fundamentals of Energy Engineering, The Fairmont Press Inc., Atlanta, Gerogia, USA.

Thumann, A and Mehta, DP 1997, Handbook of Energy Engineering, 4 edn, The Fairmont Press Inc., 700 Indian Trail, Liburn, USA.

USDA 1980, Low Temperature and Solar Grain Drying Handbook, Midwest Plan Service, Iowa State University, Ames, Iowa, USA.

Yahmadi, A 2003, 'A comparison of three renewable energy technologies for smallscale distributed generation in the Java-Bali region', Master of Engineering Science (Energy Studies) thesis, The University of Melbourne. 


\section{RESULTS AND DISCUSSION}

\subsection{Introduction}

The complete solar dryer system has been described and then modeled as in Section 5. The simulation was performed for chilli and beef at a drying air temperature of $60^{\circ} \mathrm{C}$, drying air velocity of $0.75 \mathrm{~m} / \mathrm{s}$ and drying air flow rate of $3120 \mathrm{~kg} / \mathrm{hr}$. The TMY data generated in Section 4 was used as weather data for the simulations. Although the existing dryer at Khao-kor uses oil as a supplementary energy source, for the reasons cited in Section 5.4.4, it is proposed to use electricity for the dryer in Bhutan. Thus, the results of the performance evaluation discussed in the following sections apply to electricity as a supplementary energy source.

\subsection{Thermal performance}

\subsubsection{Chilli drying}

The simulation was performed during the period August to September for the location of Paro, Bhutan (latitude: $27.44^{\circ} \mathrm{E}$; altitude: $3811 \mathrm{~m}$ ). During this period, hourly solar radiation levels varied between $0.2 \mathrm{MJ} / \mathrm{m}^{2}$ and $3.8 \mathrm{MJ} / \mathrm{m}^{2}$, ambient air temperature ranged from $5.5^{\circ} \mathrm{C}-24.7^{\circ} \mathrm{C}$ and ambient relative humidity from $64 \%-98 \%$.

\section{a. Drying time}

To determine the time taken to reduce the moisture content of chilli from $567 \%(\mathrm{db})$ to $10 \%(\mathrm{db})$, a simulation run was performed starting at 10 a.m and continuing until the moisture content was less than $10 \%(\mathrm{db})$ at various " $k$ " (drying constant) values. A " $k$ " value of 0.03 was found to give acceptable results. At this " $k$ " value, the drying time is 18 hours (Fig. 6.1) which agrees with Sitthiphong et al.'s (1989) findings. Thus chilli drying will be spread over two days i.e. 9 hours in a day. At the end of first day (after 9 hours), the moisture content of chilli is reduced from $567 \%(\mathrm{db})$ to $150 \%(\mathrm{db})$. It was assumed that over night the chilli will reabsorb $10 \%$ of the moisture and hence the initial moisture content on the second day is $165 \%(\mathrm{db})$. The drying of chilli has to be 
started at 9 a.m instead of 10 a.m to maximise the use of solar energy and end at 6 p.m. Thus, over the period August - September, 4.5 tonnes (150 kg/batch x 30 batches) of chilli could be dried with drying time of 2 days (18 hours).

\section{b. Operating schedule}

As the drying cycle of chilli determined in the preceding paragraph is two days ( 9 hours in a day) and the solar radiation is highest between 9 a.m to 6 p.m (Section 5.4.2), the dryer will be operated from 9 a.m to 6 p.m every day during the period August to September to dry chilli. The dryer has to be loaded manually in thin layers before starting the drying cycle and unloaded when the drying of the entire batch is completed i.e. 6 p.m on second day.

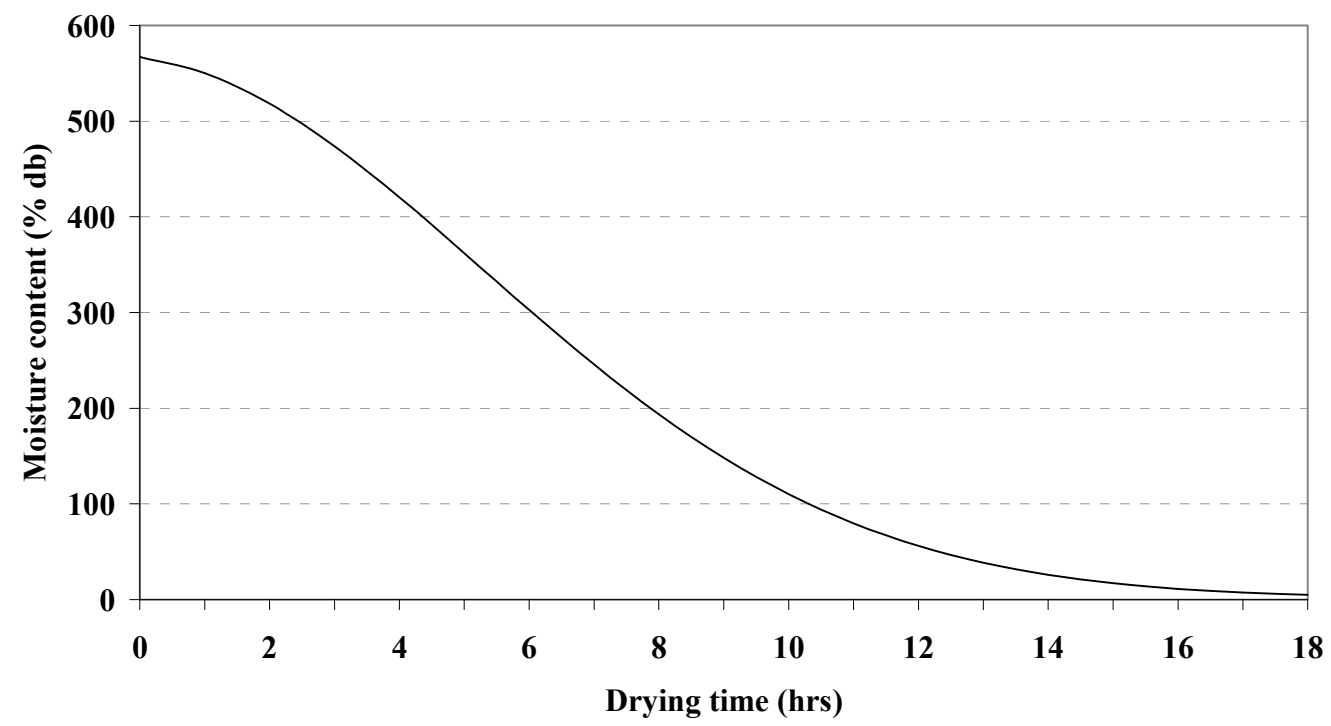

Fig. 6.1. Drying curve of chilli

\section{c. Dryer efficiency}

The hourly collector, pick-up and system efficiencies were computed using the Equations 5.4 to 5.6. The daily collector efficiency varied from 28 - 34\% while average daily pick-up efficiency ranged from $21.4-24.4 \%$ during the period of drying. The average daily system efficiency ranged from $11 \%-22 \%$. 


\section{d. Solar contribution}

The solar fraction which indicates the total solar contribution to the load is an important performance parameter of any solar energy system (Duffie \& Beckman 1991). The total quantity of energy required to reduce the moisture content of 4.5 tonnes of chilli from $567 \%(\mathrm{db})$ to $10 \%(\mathrm{db})$ is $78 \mathrm{GJ}$, i.e. $17.3 \mathrm{MJ} / \mathrm{kg}$ of fresh chilli. The total solar contribution to the load is $19 \mathrm{GJ}$ or $24.4 \%$ of the total energy required. Since the total solar energy is dependent on the climatic conditions of the location, the average solar contribution varies day to day. Fig. 6.2 shows the daily solar fraction during the period August to September. As can be seen, the average daily solar fraction varies from $3-54 \%$. This suggests that on some days solar contribution to the load is very low. This is mainly due to low radiation i.e. $2.2 \mathrm{MJ} /$ day on some days

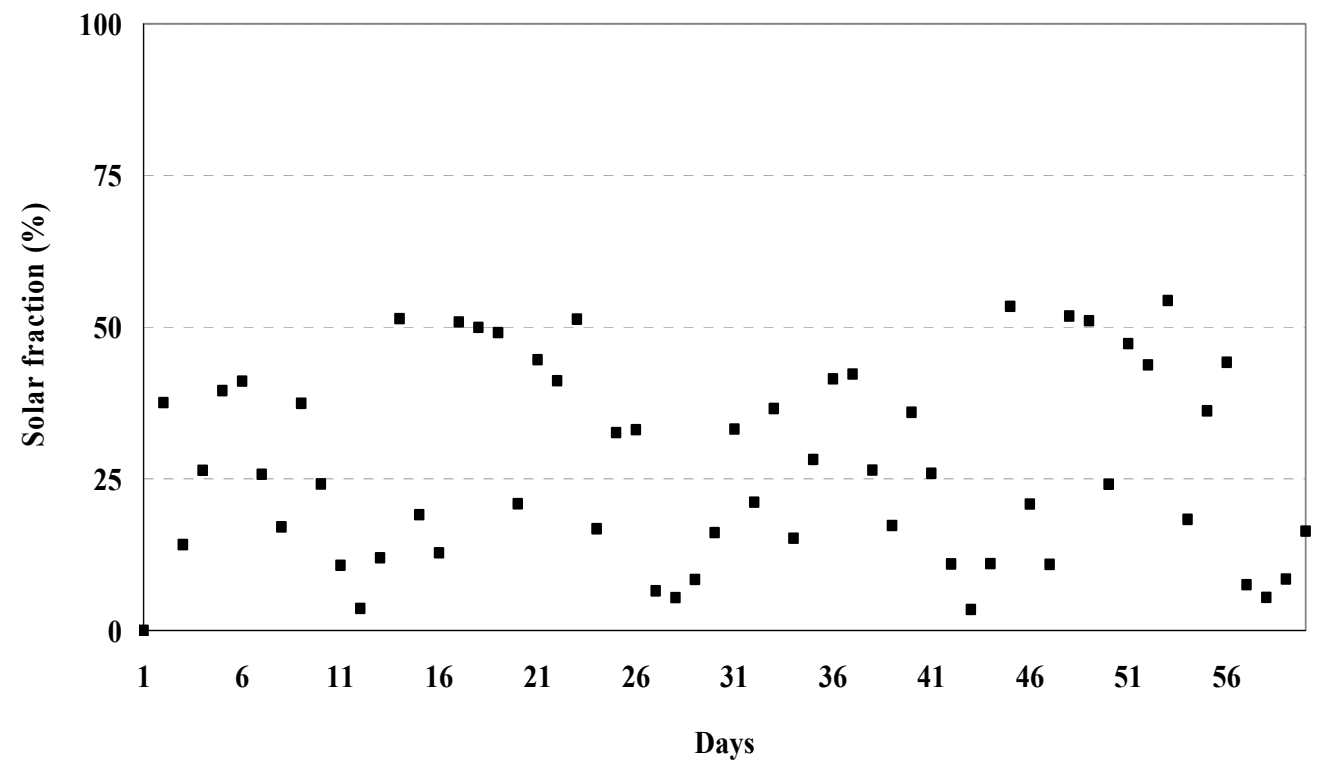

Fig. 6.2. Daily solar fraction during the period August to September

\section{e. Cost of supplementary energy}

The cost of supplementary energy source is an important parameter which determines the financial viability of the solar crop dryer. The computation of supplementary energy cost was based on the present tariff of electricity in Bhutan. The Bhutan Power Coporation (BPC) charges a 3-block progressive tariff for low voltage (230 V, single phase or $440 \mathrm{~V}$, three phase) consumers (BPC 2004). 
Block I (up to $80 \mathrm{kWh} /$ month)

Block II (between $80-200 \mathrm{kWh} /$ month)

Block III (morethan $200 \mathrm{kWh} /$ month)
: $\quad \mathrm{Nu} 0.60 / \mathrm{kWh}(\mathrm{US} \$ 1 \cong \mathrm{Nu} 45)$

: $\mathrm{Nu} 0.95 / \mathrm{kWh}$

: $\mathrm{Nu} 1.20 / \mathrm{kWh}$

The total cost of supplementary energy for drying chilli from August to September is US \$ 453 .

\subsubsection{Beef drying}

\section{a. Drying time}

Unlike the case of chilli, drying time of beef could not be determined due to the nonexistence of a drying constant in the literature and experimental determination was beyond the scope of this study. Thus drying time of beef is assumed as 8 hours based on the assumptions used by other researchers as discussed in Section 3.4.

\section{b. Operating schedule}

Although the solar radiation is highest between 10 a.m to 5 p.m (Section 5.4.2), the drying time of beef is 8 hours from the preceding paragraph, thus the operation of the dryer has to be extended by one hour more. The solar radiation from $9-10$ a.m and 5 6 p.m are equal and thus beef drying can be either from 9 a.m - 5 p.m or from 10 a.m 6 p.m. In this study beef drying is selected to be 9 a.m -5 p.m. Therefore, the dryer will be operated from 9 a.m to 5 p.m daily during the periods $1^{\text {st }}$ January to $14^{\text {th }}$ of Feb, $17^{\text {th }}$ March to $16^{\text {th }}$ May, $16^{\text {th }}$ June to $31^{\text {st }}$ July and from October to December. The dryer has to be loaded manually by hanging the beef strips over the wires fixed over the surface of dryer trough before starting the drying cycle and unloaded when the drying of entire batch is completed i.e. 5 p.m.

\section{c. Solar contribution}

The total energy required to reduce the moisture content of 24.4 tonnes (i.e. 100 $\mathrm{kg} / \mathrm{batch} \times 244$ batches) of fresh beef from $400 \%(\mathrm{db})-10 \%(\mathrm{db})$ is $291.7 \mathrm{GJ}$, i.e. 12 $\mathrm{MJ} / \mathrm{kg}$. The total solar contribution to the load was $69 \mathrm{GJ}$ or $23.6 \%$ of the total load. However, as in the case of chilli, a significant variation in solar contribution could be 
observed. The maximum daily average solar contribution is $49 \%$ while for some days in January, November and December, the solar contribution is zero (Fig. 6.3).

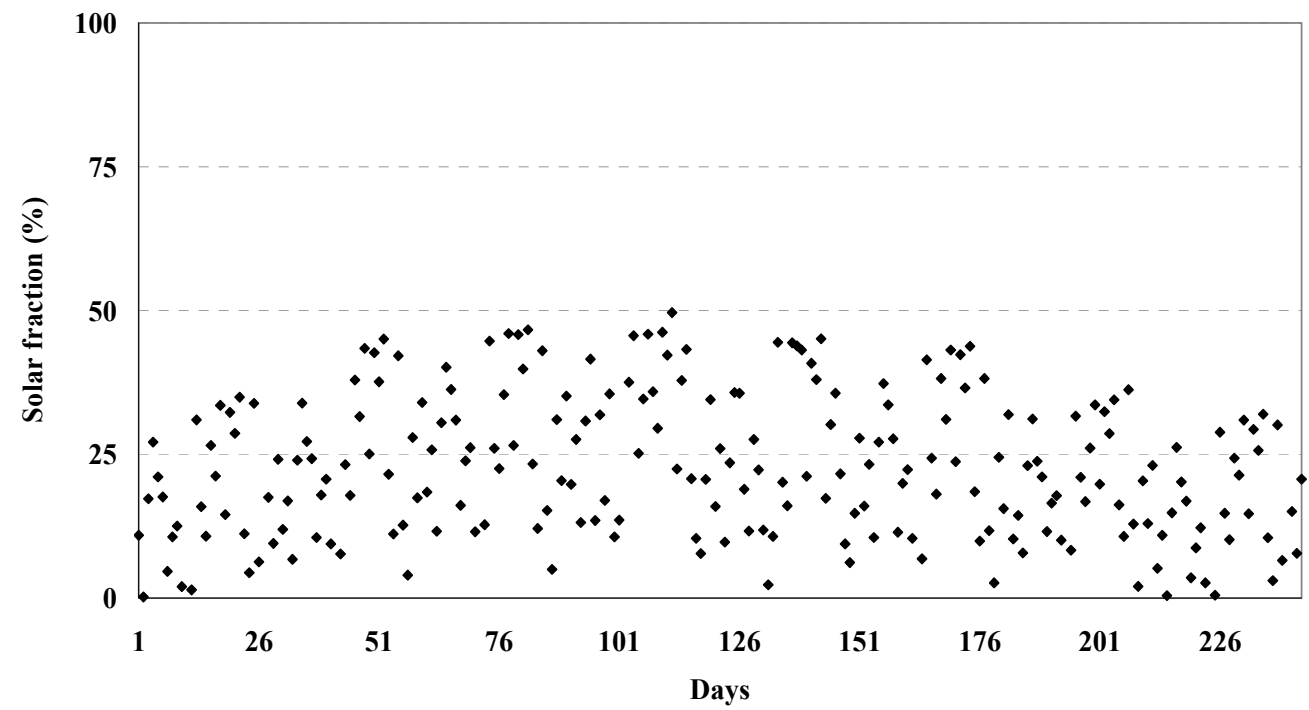

Fig. 6.3. Daily solar fraction during the periods $1^{\text {st }}$ January to $14^{\text {th }}$ of Feb, $16^{\text {th }}$ March to $14^{\text {th }}$ May, $16^{\text {th }}$ June to $31^{\text {st }}$ July and from October to December.

\section{d. Cost of supplementary energy}

The total cost of supplementary energy for drying beef is US \$ 1752 .

Table 6.1 summarises the results of thermal performance of the Khao-kor type solar dryer in Bhutan compared to that of the experimental investigation of drying chilli at Khao-kor by Swasdisevi et al. (1999). From the table, it shows that solar contribution to the load at Khao-kor is $53.5 \%$ while it is only $24 \%$ in Bhutan. The drying time of chilli in Khao-kor was 5.5 hours while it took 18 hours to dry in Bhutan. The longer drying time is due to fact that the chilli at Khao-kor was dried by slicing while the chilli in Bhutan has to be dried without any prior treatment or slicing. The collector and system efficiencies are approximately equal in both Khao-kor and Bhutan. However, there is significant difference of pick up efficiency. The high pick up efficiency could be due to short drying time for sliced chilli in Khao-kor. The total energy required for drying 4.5 tonnes of chilli and 24.4 tonnes of beef in Bhutan is 369.6 GJ. The total solar contribution to the load is $24 \%$. 
Table 6.1. Thermal performance of Khao-kor type solar dryer in Bhutan

\begin{tabular}{llrrr}
\hline \multirow{2}{*}{ Parameters } & Unit & \multicolumn{2}{c}{$\begin{array}{c}\text { Average Value in } \\
\text { Bhutan }\end{array}$} & $\begin{array}{c}\text { Results at Khao- } \\
\text { kor for chilli }\end{array}$ \\
\cline { 3 - 4 } & & Chilli & Beef & \\
\hline Drying time & hours & 18.0 & 8.0 & 5.5 \\
Pickup efficiency & $\%$ & 23.0 & n.a & 39.7 \\
Collector efficiency & $\%$ & 30.0 & 40.0 & 46.4 \\
System efficiency & $\%$ & 14.5 & 17.0 & 19.3 \\
Total solar energy & GJ & 19.0 & 68.8 & 0.369 \\
Solar fraction & $\%$ & 24.4 & 23.6 & 53.5 \\
Total supplementary energy & GJ & 58.9 & 222.9 & 0.321 \\
Cost of suplementary energy & US \$ & 453.4 & 1752.2 & - \\
\hline
\end{tabular}

(Chiili is simulated for the period Aug to Sep while beef is for the periods $1^{\text {st }}$ Jan to $14^{\text {th }}$ of Feb, $17^{\text {th }}$ Mar to $16^{\text {th }}$ May, $16^{\text {th }}$ Jun to $31^{\text {st }}$ Jul and Oct to Dec)

\subsection{Financial analysis}

The following general assumptions were used for analysis:

- Constant discount rate and inflation over the project life time

- A constant electricity price over the project life time

- There is no tax levy on the dried products

- The price of fresh product is constant through out the season in a year.

- The dried products could be sold in the market.

- The consumers are willing to pay higher price for better product.

- Capital investment fund is available

\subsubsection{Capital cost}

The major cost of solar dryer includes cost of collector, drying trough and support structures. Based on the schematic diagram in Fig. 5.2, the quantities of materials are estimated and a corresponding cost was calculated. The estimate of the total cost of Khao-kor type solar dryer in Bhutan is shown in Table 6.2 (refer Appendix 11 for itemised cost). The prices of the different items used in the study are directly quoted from the Bhutan schedule of rates (BSR)-2001 (SQCD 2001). Since the rates in BSR were for the year 2001, 5\% inflation per year (based on general practice in Bhutan) 
was assumed to reflect the price in the year 2004. The prevailing exchange rate for the current year obtained from the Royal Monetary Authority of Bhutan (RMA) (RMA 2004) was used to convert the cost in terms of US dollars (refer Appendix 12). For the items like the blower and electric duct heater which were not available in the BSR, prices were obtained directly from dealers in India. As per the dealers, these prices are approximate and the actual price may differ depending on the scope of the project.

From the Table 6.2, the total cost of the complete solar dryer system in Bhutan is US \$ 2343 .

Table 6.2: Cost estimate of solar dryer system

\begin{tabular}{lc}
\hline \multicolumn{1}{c}{ Parameters } & Amount (US \$) \\
\hline Land clearing and flooring & 148 \\
Solar collector and accessories & 1039 \\
Dryer trough and frame & 138 \\
Duct heater, blower and ducts & 817 \\
Installation and labour cost & 199 \\
Total & 2343 \\
\hline
\end{tabular}

\subsubsection{Operational cost}

The operational cost includes the supplementary energy cost, salary for the operators and cost of fresh products to be dried. The daily operational cost varies depending on the solar fraction. From Table 6.3, the annual operating cost is US \$ 34977 combining both chilli and beef drying.

\subsubsection{Cost- benefit analysis}

The cost benefit analysis was done based on the prevailing market prices for both the fresh and the dried products in Bhutan. Table 6.3 shows the cost-benefit analysis of the Khao-kor type solar dryer in Bhutan (refer Appendix 13 for chilli only and Appendix 14 for chilli and beef combined). The annual net income was computed based on the number of drying batches/year, unit cost of fresh chilli and beef and selling price of dried chilli and beef. The cost of fresh chilli and beef are US $\$ 1$ and 1.2/ $\mathrm{kg}$ 
respectively. While the maximum selling price of dried chilli and beef are US \$ 5 and $5.4 / \mathrm{kg}$ respectively (Wangmo 2004). As there is no price regulation at present, these prices differ according to the quality and season of products sold (Wangmo 2004). From the table, it can be seen that the NPV is negative for both chilli and beef combined and hence no payback period. The negative value indicates that there is no net return from the investment in solar dryer and thus the system is financially not viable for investment in Bhutan. Also, the BCR is less than one. This further suggests that the system is not worth the investment.

Table 6.3. Cost-benefit analysis

\begin{tabular}{lcr}
\hline \multirow{1}{*}{ Parameters } & \multicolumn{2}{c}{ Amount (US \$) } \\
\cline { 2 - 3 } & Chilli only & Combined \\
\hline Capital cost & 2343 & 2343 \\
Operating cost & 4943 & 34977 \\
Benefits & 3682 & 33121 \\
Discounted cash flow analysis & & \\
$\quad$ Discounted revenue & 23796 & 214043 \\
Discounted O \& M cost & 31941 & 226037 \\
Net present value & -10413 & -14262 \\
Benefit cost ratio & 0.70 & 0.94 \\
Internal rate of return & - & - \\
Discounted payback period & - & - \\
\hline
\end{tabular}

Summarising the results of performance evaluation, it can be seen that although the thermal performance of the Khao-kor type solar dryer is satisfactory in Bhutan, the system is not financially feasible for replication in Bhutan. Further, it is evident that the cost of supplementary energy source is rather high and depends on the size of system and also on duration and time of use. The alternative options are to increase the price of the dried products or to reduce the use of supplementary energy source. The reduction in supplementary energy may be achieved by using a lower drying air temperature or increasing the collector area. While reduction in drying air temperature will increase the drying time of both chilli and beef, over-sizing of the collector will make the system too expensive and may still not be affordable. Also, the prices of the 
dried products are beyond the control of the dryer owner. Thus an alternative option is to minimise the cost of the drying by optimising the complete solar dryer system.

\subsection{Optimisation}

The purpose of optimisation in this study is to find the area of the collector that gives minimum annual drying cost. The overall cost of the system comprises of two different costs as shown in Equation 6.1 i.e. annual cost of dryer system cost and supplementary energy cost (Kreider et al. 1989). Both the costs depend on the size of the collector.

$$
\begin{aligned}
C_{\text {tot }} & =\quad C a+C_{f} \\
\text { where } C_{\text {tot }} & =\text { Total cost expressed on annual basis (US \$/year) } \\
C_{a} & =\text { Annual cost of dryer system (US \$/year) } \\
C_{f} & =\text { Annual cost of supplementary energy (US \$/year) }
\end{aligned}
$$

Audsley and Wheeler (1978) proposed an equation to compute the annual cost based on the initial capital cost, salvage value of the materials and repair and maintenance cost. This Equation 6.2 has been used by Hossain et al. (2004) and Simate (2003) to optimise the solar crop dryers.

$$
\begin{aligned}
C a & =\left(C_{t}+\sum_{i=1}^{n} m_{i} w^{i}-S_{n} w^{n}\right) \times \frac{(w-1)}{w \times\left(w^{n}-1\right)} \\
w & =\frac{1+g}{1+r} \\
\text { Where, } C_{t} & =\quad \text { Initial capital cost (US \$) } \\
m_{i} & =\quad \text { Current value of maintenance cost in } \mathrm{i}^{\text {th }} \text { year (US \$) } \\
S_{n} & =\quad \text { Current value of residual value (US \$) } \\
n & =\quad \text { Project life time (years) } \\
g & =\quad \text { Inflation rate }(\%) \\
r & =\quad \text { Interest rate }(\%)
\end{aligned}
$$

Further the initial capital cost comprises of two different costs, fixed cost and a variable cost which is dependent on collector area and is explained in the next section. 


\subsubsection{Optimisation procedure}

The process of optimisation in this study is described below.

i. The first step is to calculate the annual cost of dryer system as explained below.

- $\quad$ Fixed cost

The fixed cost includes the cost of electric duct heater, blower, ducts and dryer trough. The fixed and variable costs are calculated in Table 6.4. The fixed cost is US \$ 1174 .

- Variable cost

The variable cost comprises of cost of collector, insulation, glazing, support structures and paint. The variable cost is US $\$ 16 / \mathrm{m}^{2}$.

Table 6.4: Fixed and variable cost

\begin{tabular}{lrr}
\hline Particulars & $\begin{array}{c}\text { Fixed cost } \\
\text { US \$ }\end{array}$ & $\begin{array}{c}\text { Variable cost } \\
\text { US \$ }\end{array}$ \\
\hline Land clearing & 111 & 37 \\
Collector accessoroes & 0 & 1039 \\
Dryer trough & 138 & 0 \\
Heater and blower & 817 & 0 \\
Installation & 107 & 104 \\
Total & 1174 & 1180 \\
Per unit cost (US \$/m2) & - & 16 \\
\hline
\end{tabular}

\section{- Maintenance cost}

The annual maintenance cost is assumed as $2 \%$ of the total capital investment and further assumed to incur after every five years of operation.

\section{- Salvage value}

As the life time of CGI sheets are more than 20 years, the salvage value is assumed as $20 \%$ of the initial investment.

ii. A collector area is selected and system is simulated for both the chilli and beef for entire periods mentioned in Section 6.2.1 and 6.2.2. Based on the simulation results, the cost of supplementary energy and total annualised cost determined (Appendix 15). 
iii. This calculation sequence is repeated until a minimum point of total cost is found.

In this study, the calculation was done in the steps of $10 \mathrm{~m}^{2}$ and maximum collector area of $200 \mathrm{~m}^{2}$. Fig A.3 shows a plot of the collector area and the annualised total cost.

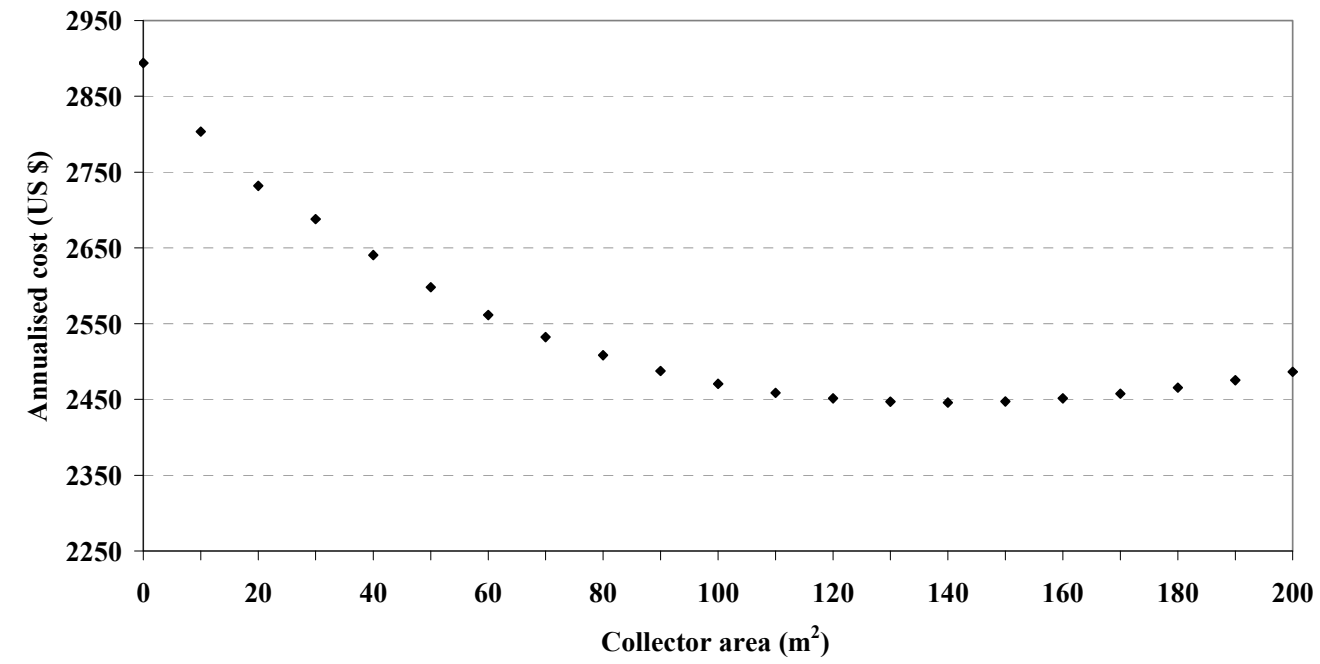

Fig. 6.4. Plot of annual cost and solar collector area

From the figure, it can be seen that the optimum size of the solar collector is $140 \mathrm{~m}^{2}$. At this collector area, the annualised total cost of the system is US \$2446. If the system were to use electricity only without any solar components then the annualised total cost is US \$2894.

\subsubsection{Optimised performance}

The optimised system has been simulated for both chilli and beef, i.e. 30 and 244 batches of chilli and beef per year respectively. The optimised thermal performance is depicted in Table 6.5. The optimisation increased average annual solar contribution of the system from $24 \%$ to $33 \%$ of the total load (and therefore decreased annual supplementary energy cost from US \$2206 to US \$1985). 
Table 6.5: Thermal performance of optimised system

\begin{tabular}{llcr}
\hline \multirow{2}{*}{ Parameters } & \multirow{2}{*}{ Unit } & \multicolumn{2}{c}{ Average value } \\
\cline { 3 - 4 } & & Chilli & Beef \\
\hline Drying time & hours & 18.0 & 8.0 \\
Pickup efficiency & $\%$ & 15.8 & n.a \\
Collector efficiency & $\%$ & 30.6 & 48.0 \\
System efficiency & $\%$ & 18.7 & 17.0 \\
Total solar energy & GJ & 26.7 & 94.5 \\
Solar fraction & $\%$ & 33.6 & 32.2 \\
Total supplementary energy & GJ & 52.7 & 199.3 \\
Cost of suplementary energy & US \$ & 408.0 & 1577.2 \\
\hline
\end{tabular}

A cost-benefit analysis of the optimised solar dryer is compared with electric heating system and is summarised in Table 6.6 (detail in Appendix 16). The NPV of solar system is higher than the electric heating system which indicates that the solar dryer system is likely to be more feasible compared to an electric heating system. However, from the table it can be seen that the NPV of both the systems are negative. The negative values indicate that neither of the systems are financially viable in Bhutan.

Table 6.6: Cost-benefit analysis of optimised system

\begin{tabular}{lrc}
\hline \multirow{2}{*}{ Parameters } & \multicolumn{2}{c}{ Amount ( US \$) } \\
\cline { 2 - 3 } & Solar system & $\begin{array}{c}\text { Electrical heating } \\
\text { system }\end{array}$ \\
\hline Capital cost & 3437 & 1174 \\
Operating cost & 34751 & 35506 \\
Benefits & 33121 & 33121 \\
Discounted cash flow analysis & & \\
Discounted revenue & 214043 & 214043 \\
Discounted O \& M cost & 224572 & 229455 \\
Net present value & -13856 & -16549 \\
Benefit cost ratio & 0.94 & 0.93 \\
Internal rate of return & - & - \\
Discounted payback period & - & - \\
\hline
\end{tabular}




\subsubsection{Drying cost}

The drying cost $C_{d}$ of any product is given by Equation 6.3 as the ratio of annual cost to quantity of product dried per year (Radajewski et al. 1987).

$$
C_{d}=\frac{\text { Annualised total cost }}{\text { Quantity of product dried per year }}=\frac{C_{t o t}}{Q_{p}}
$$

The annualised cost for the optimised system is US \$ 2446 as calculated in the preceding sections. The drying costs for solar system are US \$ 7.94 and 5.96 per kg dry matter for chilli and beef respectively. The corresponding costs for electrical heating system is US \$ 7.76 and 6.25 per kg of dry matter for chilli and beef respectively.

From the comparison of the costs of the dry matter of chilli and beef in Table 6.6, the cost of fresh chilli is US $\$ 6.67 / \mathrm{kg}$ of dry matter while the cost of dried chilli is US $\$ 5.58 / \mathrm{kg}$ of dry matter. This indicates that at $10 \%$ final moisture content, dried chilli fetches lower price than the fresh chilli. The reason for this could be that the final moisture content of dried chilli in the local market in Bhutan may be higher than the $10 \%$ assumed in this study. Thus an alternative approach is to investigate the moisture content of dried chilli and beef in the local market in Bhutan, and then another analysis can be performed to determine the financial viability of the solar dryer system. The complete system would be financially viable if the final moisture content of chilli and beef are assumed as $15 \%(\mathrm{db})$.

Table 6.7: Cost of chilli and beef

\begin{tabular}{lcc}
\hline \multirow{2}{*}{ Product } & \multicolumn{2}{c}{ US \$/kg of dry matter } \\
\cline { 2 - 3 } & Solar dryer & Electrical heating system \\
\hline Fresh chilli & 6.67 & 6.67 \\
Drying cost of chilli & 7.94 & 7.76 \\
Dried chilli & 5.58 & 5.58 \\
Fresh beef & 5.83 & 5.83 \\
Drying cost of beef & 5.96 & 6.25 \\
Dried beef & 6.17 & 6.17 \\
\hline
\end{tabular}




\subsection{Conclusions}

The thermal and financial performance of Khao-kor type solar dryer has been evaluated in the preceding sections for replication in Bhutan. The system has been optimised to minimise the annual drying cost. Although the potential for using solar dryer is high in Bhutan, from the financial evaluation it is evident that the Khao-kor type solar drying is financially not viable in Bhutan. Further, a complete electric heating system is also not viable financially. However, compared to the non-solar system dryer, a solar dryer is more attractive. Further analysis is required to determine the dryness of the dried chilli and beef sold in the local market in Bhutan, and then another analysis can be performed to determine the financial viability of the solar dryer system.

\subsection{References}

Audsley, E and Wheeler, J 1978, 'The annual cost of machinery calculated using actual cash flows', Journal of Agricultural Engineering Research, vol. 23, no. 2, pp. 189-201.

BPC 2004, Electricity Tariffs, Bhutan Power Corporation, viewed 6 November 2004, $<$ http://www.bpc.com.bt/CSD/csd1d.html $>$.

Duffie, JA and Beckman, WA 1991, Solar Engineering of Thermal Processes, 2nd edn, John Wiley and Sons Inc., Wisconsin-Madison, USA.

Hossain, MA, Woods, JL and Bala, BK 2004, 'Optimisation of solar tunnel drier for drying of chilli without color loss', Renewable Energy, vol. In Press, Corrected Proof.

Kreider, JF, Hoogendoorn, CJ and Kreith, F 1989, Solar Design: Components, Systems, Economics, Hemisphere Publishing Corporation, New York, USA. 
Radajewski, W, Jolly, P and Abawi, GY 1987, 'Optimisation of solar grain drying in a continuous flow dryer', Journal of Agricultural Engineering Research, vol. 38, no. 2 , pp. 127-44.

RMA 2004, Selected Economic Indicators, 2, Royal Monetary Authority of Bhutan, Thimphu, Bhutan.

Simate, IN 2003, 'Optimization of mixed-mode and indirect-mode natural convection solar dryers', Renewable Energy, vol. 28, no. 3, pp. 435-53.

Sitthiphong, N, Hirun, A, Klongpanich, W, Thertoon, P, Siratanapanta, T, Thavornun, S and Kamalaspitak, S 1989, Final Report Chapter 2: Multi-Crop Dryers Project First Phase (1986 - 1988), The International Development Research Centre, Canada.

SQCD 2001, Bhutan Schedule of Rates - 2001 (Civil), Standard and Quality Control Division, Royal Government of Bhutan, Ministry of Communications, Thimphu, Bhutan.

Swasdisevi, T, Soponronnarit, S, Rakwichian, W and Thadnium, V 1999, 'IndustrialScale Solar Vegetable Drying', paper presented to World Renewable Energy Congress, Murdoch University, Western Australia, 10-13 February 1999,.

Wangmo, D 2004, Personal communication, Assistant Agriculture Extension Agent, Phuentsholing, Bhutan. 


\section{RECOMMENDATIONS AND CONCLUSIONS}

\subsection{Recommendations}

The development of solar dryers in Bhutan should be encouraged. The potential for using solar dryers is high in Bhutan. It is suggested that significant support should be provided for the development of solar dryers. Subsidies in the form of exemption from sales tax on CGI sheets and timber could reduce the cost of dryers.

From the technical and financial evaluation of the Khao-kor type solar dryer, the following are recommended for adaptation for Bhutan.

- The physical dimensions, drying temperature and air flow rate are recommended to remain the same as the thermal performance of the dryer is satisfactory. However, the collector area needs to be increased to $140 \mathrm{~m}^{2}$ for the system to be viable at proposed final moisture content of dried chilli and beef at $15 \%(\mathrm{db})$.

- Although the dryer at Khao-kor has four drying units, only one unit is recommended for use in Bhutan.

- For the reasons cited in preceding sections, an electric heater is recommended as a back-up heating source.

- Batch size of chilli is $150 \mathrm{~kg}$ and can be dried in thin layers.

- Batch size of beef is $100 \mathrm{~kg}$ and has to be dried by slicing into strips.

- The dryer trough needs to be modified with wires on the top surface for hanging beef.

- The dryer has to be operated from 9 a.m - 6 p.m during the period August to September to dry chilli.

- Beef could be dried from 9 a.m -5 p.m during the periods $1^{\text {st }}$ January to $14^{\text {th }}$ of Feb, $17^{\text {th }}$ March to $16^{\text {th }}$ May, $16^{\text {th }}$ June to $31^{\text {st }}$ July and from October to December. 


\subsection{Conclusions}

Globally drying is the most widely used method for preserving food for use in the home or for sale. The drying process consists of evaporation of water content of product from the surface to the surrounding medium and movement of water from inside the product to the surface by means of diffusion. Air is used both as a medium to transfer heat to the product as well as to carry away the water from the surface. However, air has to be heated to certain level of temperature based on safe drying temperature to increase the moisture absorption capacity. The heating of air can be achieved by using any conventional heaters but these are expensive to run. Thus solar dryers are preferred for their inexpensive operating cost.

The different types of solar dryers have been explained in the Section 3. Although the benefits of using solar dryers are immense, the acceptance level is still low. The reasons for low acceptance rate calls for appropriate technology that suits the developing countries. Any proposed technology needs proper evaluation before implementing it. To assess the performance of a solar crop dryer requires meteorological data for the location proposed of which Bhutan has none at the time of this study. Thus the Type 54 weather generator has been proposed to use for solar simulation in Bhutan. The outputs of the Type 54 weather generator have been validated for inputs from NASA and AMLTO in Section 4. The results of validation indicate that the Type 54 can be used for simulating solar energy systems where meteorological data has not been observed. However, when the inputs to the Type 54

are extracted from NASA, the variation is significant and thus one needs to be cautious while designing solar energy systems.

An existing solar dryer at Khao-kor, Thailand has been evaluated for possible adaptation in Bhutan. The system has been modeled using TRNSYS (version 15.3). The subroutine for the dryer trough which is not available in the TRNSYS library has been modeled using visual FORTRAN and exported to TRNSYS as a Type 104.

The technical performance of the dryer was found satisfactory, however from the business point of view; the dryer is financially not viable in Bhutan. Nevertheless compared to the non-solar system dryer, solar dryer is more attractive than the non- 
solar system. The total investment cost for a non optimised solar dryer is US \$ 2343 . The corresponding cost for an optimised system is US \$ 3437 and for an electric heating system dryer is US \$ 1174 . The NPV of the optimised solar system dryer is US \$ -13 856 while NPV of an electric heating system dryer is US \$ -16549 . The negative NPV is unlikely to attract private investors.

The benefits of using any dryer is small as there is only small price difference between fresh and dried products. Unless the price of the dried products is increased, it is unlikely that any commercial dryer would be viable in Bhutan. Nevertheless, the potential for using solar dryers is high in Bhutan. With average solar radiation of 16.6 $\mathrm{MJ} / \mathrm{m}^{2} /$ day, the solar dryer in this study can contribute about $33 \%$ of the load. In spite of high solar contribution, the system is still not viable. This is mainly due to the low price of the dried products especially chilli. From the comparison of the price of dry matter for both fresh and dried beef, it is more likely that the final moisture content of dried chilli sold in the local market in Bhutan is more than 10\%. Thus the proposed dryer could be viable if the final moisture content of chilli and beef is maintained at $15 \%(\mathrm{db})$.

Chilli and beef are used in the evaluation of the dryer because they are popular and traditionally sun dried. There are no apparent reasons why other crops currently sun dried could not be dried successfully in the proposed dryer provided the safe drying temperature is not less than $60^{\circ} \mathrm{C}$.

However, the complete analysis is based on the meteorological data generated by the Type 54 weather generator using average data from NASA as inputs. Since the data from NASA are not as accurate as ground measurement, the results may vary compared to the real ground measurements. 


\subsection{Further studies}

This study has given rise to the following areas which need further study and analysis.

- Moisture content of dried chilli and beef available in the local market in Bhutan.

- Sale of dried chilli and beef to predict further financial viability.

- A similar study for different crops and regions of Bhutan.

- Experimental verification of the proposed solar dryer system by building prototype before implementing full dryer system to verify the simulation results. 


\section{APPENDICES}

\section{Appendix 1: Country Background}

Bhutan - a rugged mountainous country lies sandwiched between India on the South, East and West and the Tibetan part of China on the North (CSO 2003). Bhutan is located between $26^{\circ} 45^{\prime}$ North to $28^{\circ} 10^{\prime}$ North latitude and $88^{\circ} 45^{\prime}$ 'East to $92^{\circ} 10^{\prime}$ 'East longitude (Yuden 2000). It comprises a land area of 38394 square kilometres with $72.5 \%$ under forest cover. The country has a population of only 716424 as per the census in 2002 and about $21 \%$ of people live in the urban areas (CSO 2003). About $80 \%$ of the population depends on agriculture for daily life and only $7.7 \%$ of the total area is used for agriculture. The altitude varies from $100 \mathrm{~m}$ in the south to $7500 \mathrm{~m}$ in the northern regions (CSO 2003).

Bhutan has three main land structures; the southern foothills rising from $100 \mathrm{~m}$ to 1500 $\mathrm{m}$ above sea level. This region is mostly covered with thick forests. The central region of Bhutan rises from $1500 \mathrm{mto} 3000 \mathrm{~m}$ above sea level. This region is considered as the economic heartland of Bhutan. The northern region comprises Himalayan ranges and rises up to $7500 \mathrm{~m}$ above sea level (CSO 2003). Bhutan has a scattered settlement pattern and is sparsely populated. The entire country is divided into twenty districts for administrative purposes. The districts are further divided into blocks and villages.

Firewood has traditionally been the major source of domestic energy in Bhutan. Although it still represents the major domestic energy consumption, the trend for firewood usage is on decline due to the availability of cheap electricity from hydropower. Hydroelectricity contributed $56 \%$ of total commercial energy consumption in 2001 (CSO 2003). Bhutan has no reserves of any fossil fuel resources; so all petroleum products are imported. Bhutan's annual domestic consumption of electricity increased from $338 \mathrm{MWh}$ in 1995 to $532 \mathrm{MWh}$ in 2000 (PCS 2002). Bhutan exports $75 \%$ of total electricity generated to India. 
Appendix 2: Total chilli produced and traded in 2000

\begin{tabular}{lrc}
\hline \multicolumn{1}{c}{ District } & $\begin{array}{c}\text { Quantity produced } \\
\text { (tonne) }\end{array}$ & $\begin{array}{c}\text { Quantity traded } \\
\text { (tonne) }\end{array}$ \\
\hline Bumthang & 28.9 & 3.7 \\
Chhukha & 150.9 & 86.7 \\
Dagana & 32.4 & 3.2 \\
Gasa & 11.9 & 0.9 \\
Ha & 10.6 & 0.3 \\
Lhuentse & 151.3 & 2.6 \\
Mongar & 154.4 & 23.8 \\
Paro & 707.8 & 347.6 \\
Pemagatshel & 74.3 & 16.3 \\
Punakha & 363.2 & 142.0 \\
Samdrupjongkhar & 44.9 & 3.7 \\
Samtse & 5.1 & 1.0 \\
Sarpang & 22.5 & 2.8 \\
Thimphu & 175.6 & 69.1 \\
Trashigang & 237.8 & 44.0 \\
Trashiyangtse & 136.4 & 24.0 \\
Tsirang & 48.1 & 9.7 \\
Trongsa & 99.3 & 27.7 \\
Wangdiphodrang & 365.5 & 115.8 \\
Zhemgang & 27.5 & 1.3 \\
Total & 2849 & 926 \\
\hline
\end{tabular}

Source: (MoA 2000) 


\section{Appendix 3: Input data from NASA satellite}

\begin{tabular}{|c|c|c|c|c|c|c|c|c|c|c|c|c|}
\hline Months & Jan & Feb & Mar & Apr & May & Jun & Jul & Aug & Sep & Oct & Nov & Dec \\
\hline \multicolumn{13}{|c|}{ Canberra, Latitude: $35^{\circ} 19^{\prime}$ South; Longitude : $149^{\circ} 11^{\prime}$ East } \\
\hline Monthly average daily global horizontal radiation $(\mathrm{kJ} / \mathrm{m} 2)$ & 23688 & 20988 & 17532 & 12672 & 9288 & 7884 & 8424 & 11160 & 15264 & 19584 & 22392 & 23508 \\
\hline Monthly average humidity ratio ( $\mathrm{g}$ water/kg air) & 12.2 & 12.1 & 10.8 & 9.2 & 7.8 & 6.5 & 6.1 & 6.5 & 7.6 & 8.9 & 10.1 & 11.4 \\
\hline Wind speed $(\mathrm{m} / \mathrm{s})$ & 3.58 & 3.56 & 3.44 & 3.56 & 3.53 & 3.93 & 4.28 & 4.38 & 4.09 & 4.04 & 3.58 & 3.59 \\
\hline Monthly average temperature $\left({ }^{\circ} \mathrm{C}\right)$ & 19.8 & 19.6 & 17.5 & 14.3 & 11.2 & 8.0 & 7.0 & 8.0 & 10.3 & 12.9 & 15.1 & 17.5 \\
\hline \multicolumn{13}{|c|}{ Hobart. Latitude: $42^{\circ} 53^{\prime}$ South; Longitude : $147^{\circ} 20^{\prime}$ East } \\
\hline Monthly average daily global horizontal radiation $\left(\mathrm{kJ} / \mathrm{m}^{2}\right)$ & 21492 & 19188 & 14580 & 9828 & 6444 & 5184 & 6048 & 8676 & 12960 & 17208 & 21312 & 22248 \\
\hline Monthly average humidity ratio ( $\mathrm{g}$ water/kg air) & 8.7 & 8.4 & 8.2 & 7.6 & 6.8 & 6.0 & 5.9 & 6.0 & 6.5 & 7.2 & 7.9 & 8.5 \\
\hline Wind speed $(\mathrm{m} / \mathrm{s})$ & 5.71 & 5.60 & 5.55 & 5.77 & 5.99 & 6.67 & 6.64 & 6.73 & 6.60 & 6.45 & 5.86 & 5.61 \\
\hline Monthly average temperature $\left({ }^{\circ} \mathrm{C}\right)$ & 15.50 & 15.20 & 14.30 & 12.60 & 10.30 & 8.22 & 7.78 & 8.10 & 9.21 & 10.70 & 12.40 & 14.00 \\
\hline \multicolumn{13}{|c|}{ Melbourne, Latitude: $37^{\circ} 49^{\prime}$ South; Longitude : $144^{\circ} 58^{\prime}$ East } \\
\hline Monthly average daily global horizontal radiation $\left(\mathrm{kJ} / \mathrm{m}^{2}\right)$ & 24408 & 22392 & 17136 & 12240 & 8244 & 6624 & 7344 & 10044 & 14184 & 18972 & 22608 & 23256 \\
\hline Monthly average humidity ratio ( $\mathrm{g}$ water/kg air) & 10.5 & 10.3 & 9.7 & 8.3 & 7.3 & 6.3 & 6.1 & 6.3 & 7.2 & 8.4 & 9.4 & 10.4 \\
\hline Wind speed $(\mathrm{m} / \mathrm{s})$ & 3.53 & 3.46 & 3.29 & 3.43 & 3.32 & 3.60 & 3.70 & 4.07 & 3.72 & 3.71 & 3.52 & 3.49 \\
\hline Monthly average temperature $\left({ }^{\circ} \mathrm{C}\right)$ & 18.7 & 19.2 & 17.5 & 13.9 & 10.6 & 8.0 & 7.3 & 7.9 & 10.0 & 12.4 & 14.5 & 16.7 \\
\hline
\end{tabular}

Source: (NASA 2004a)

\section{Appendix 4: Input data from long-term observed data}




\begin{tabular}{|c|c|c|c|c|c|c|c|c|c|c|c|c|}
\hline Months & Jan & Feb & Mar & Apr & May & Jun & Jul & Aug & Sep & Oct & Nov & Dec \\
\hline \multicolumn{13}{|c|}{ Canbera, Latitude: $35^{\circ} 19^{\prime}$ South; Longitude : $149^{\circ} 11^{\prime}$ East } \\
\hline Monthly average daily global horizontal radiation $\left(\mathrm{kJ} / \mathrm{m}^{2}\right)$ & 25890 & 23280 & 18510 & 14420 & 11020 & 8630 & 9540 & 12720 & 17830 & 21120 & 24870 & 26690 \\
\hline Monthly average humidity ratio (g water/kg air) & 8.4 & 8.8 & 8.0 & 6.7 & 5.7 & 4.9 & 4.4 & 4.6 & 5.4 & 6.1 & 6.8 & 7.5 \\
\hline Wind speed $(\mathrm{m} / \mathrm{s})$ & 3.27 & 2.92 & 2.82 & 2.82 & 2.90 & 3.17 & 3.47 & 4.07 & 4.22 & 4.31 & 4.06 & 3.83 \\
\hline Monthly average temperature $\left({ }^{\circ} \mathrm{C}\right)$ & 20.3 & 19.6 & 17.5 & 13.1 & 8.7 & 6.4 & 5.3 & 6.7 & 9.2 & 12.4 & 15.3 & 18.4 \\
\hline \multicolumn{13}{|c|}{ Hobart, Latitude: $42^{\circ} 53^{\prime}$ South; Longitude : $147^{\circ} 20^{\prime}$ East } \\
\hline Monthly average daily global horizontal radiation $\left(\mathrm{kJ} / \mathrm{m}^{2}\right)$ & 23190 & 19940 & 15130 & 10610 & 6650 & 5090 & 5510 & 8480 & 13150 & 17960 & 20790 & 23190 \\
\hline Monthly average humidity ratio ( $\mathrm{g}$ water/kg air) & 7.8 & 7.9 & 7.6 & 7.3 & 6.2 & 5.6 & 5.2 & 5.6 & 6.0 & 6.8 & 7.4 & 8.0 \\
\hline Wind speed $(\mathrm{m} / \mathrm{s})$ & 5.13 & 4.78 & 4.44 & 4.29 & 3.75 & 3.56 & 3.75 & 4.22 & 5.01 & 5.29 & 5.42 & 5.39 \\
\hline Monthly average temperature $\left({ }^{\circ} \mathrm{C}\right)$ & 16.4 & 16.5 & 15.2 & 12.8 & 10.4 & 8.4 & 7.9 & 8.9 & 10.6 & 12.1 & 13.7 & 15.2 \\
\hline \multicolumn{13}{|c|}{ Melbourne, Latitude: $37^{\circ} 49^{\prime}$ South; Longitude : $144^{\circ} 58^{\prime}$ East } \\
\hline Monthly average daily global horizontal radiation $\left(\mathrm{kJ} / \mathrm{m}^{2}\right)$ & 24870 & 21460 & 16690 & 11580 & 7270 & 6250 & 6930 & 9650 & 13170 & 18170 & 21920 & 24190 \\
\hline Monthly average humidity ratio ( $\mathrm{g}$ water $/ \mathrm{kg}$ air) & 8.7 & 9.2 & 8.5 & 7.6 & 6.8 & 6.1 & 5.7 & 5.7 & 6.1 & 6.7 & 7.4 & 8.7 \\
\hline Wind speed $(\mathrm{m} / \mathrm{s})$ & 3.63 & 3.43 & 3.21 & 3.14 & 3.15 & 3.15 & 3.22 & 3.60 & 3.86 & 4.09 & 4.13 & 3.92 \\
\hline Monthly average temperature $\left({ }^{\circ} \mathrm{C}\right)$ & 19.8 & 19.8 & 18.3 & 15.2 & 12.4 & 10.2 & 9.9 & 10.6 & 12.3 & 14.3 & 16.3 & 18.7 \\
\hline
\end{tabular}

\section{Source: (Unimelb 1980)}




\section{Appendix 5: Accuracy of NASA data}

NASA compared values obtained from satellites with ground site measurements. The uncertainty estimates were done for insolation, temperature, surface pressure, relative humidity and wind speed. The estimated root mean square (RMS) bias and the methods used are given below.

\begin{tabular}{|c|c|c|}
\hline Parameter & Method & RMS (Bias) \\
\hline Horizontal Insolation & SSE satellite-based Staylor & 10 to $17 \%(+3 \%)$ \\
\hline \multirow{2}{*}{ Horizontal Diffuse Radiation } & $\mathrm{SSE} /$ Erbs et al. correlation & $\sim 18 \%(+4 \%)$ \\
\hline & SSE/Extended Page (74 reference sites) & $\sim 20 \%(+3 \%)$ \\
\hline \multirow{2}{*}{ Direct Normal Radiation } & $\begin{array}{l}\text { SSE/RETScreen-type (hourly angular } \\
\text { conversion) }\end{array}$ & $\sim 15 \%(-9 \%)$ \\
\hline & $\begin{array}{l}\text { SSE/Extended Page (empirical Staylor } \\
\text { angular conversion) }\end{array}$ & $\sim 24 \%(+2 \%)$ \\
\hline \multirow{2}{*}{$\begin{array}{l}\text { Flat, Rough Grass Wind (10-m } \\
\text { height) }\end{array}$} & Documented $10-\mathrm{m}$ height airport sites & $1.3 \mathrm{~m} / \mathrm{s}(-0.2 \mathrm{~m} / \mathrm{s})$ \\
\hline & Unknown-height airport sites & $1.3 \mathrm{~m} / \mathrm{s}(-0.0 \mathrm{~m} / \mathrm{s})$ \\
\hline \multirow{5}{*}{ Air Temperature, K (10-m height) } & Global sites $<243 \mathrm{~K}$ & $3.2 \%$ (NA) \\
\hline & Global sites $>263 \mathrm{~K}$ & $1.1 \%$ (NA) \\
\hline & Global sites between $243 \mathrm{~K}$ and $263 \mathrm{~K}$ & linear variation \\
\hline & 200 potential renewable energy sites & $1.2 \%(\mathrm{NA})$ \\
\hline & in 7 continental regions & \\
\hline \multirow{2}{*}{ Relative Humidity, \% } & Global & $18.5 \%$ (NA) \\
\hline & 200 potential renewable energy sites & $10 \%$ (NA) \\
\hline Surface Pressure, $\mathrm{kPa}$ & Global & $3.8 \%$ (NA) \\
\hline
\end{tabular}

\section{Source: (NASA 2004b)}


Appendix 6: Solar dryer performance evaluation parameters in the literature

\begin{tabular}{|c|c|c|c|c|c|c|c|c|c|c|}
\hline Authors & $\begin{array}{l}\text { Drying } \\
\text { time/rate }\end{array}$ & $\begin{array}{c}\text { Drying } \\
\text { temp. }\end{array}$ & $\begin{array}{l}\text { Air flow } \\
\text { rate }\end{array}$ & $\begin{array}{l}\text { Drying } \\
\text { capacity }\end{array}$ & $\begin{array}{c}\text { Quality of } \\
\text { dried } \\
\text { product }\end{array}$ & \begin{tabular}{|c|} 
Energy \\
consumption \\
for drying
\end{tabular} & $\begin{array}{c}\text { Cost of } \\
\text { dryer/pay } \\
\text { back }\end{array}$ & $\begin{array}{c}\text { Temp. \& } \\
\text { RH of air }\end{array}$ & $\begin{array}{c}\text { Loading/ } \\
\text { unloading } \\
\text { convenience }\end{array}$ & Others \\
\hline Arinze et al., 1999 & $\checkmark$ & $\checkmark$ & $\checkmark$ & $\checkmark$ & $\checkmark$ & $\checkmark$ & $\checkmark$ & $\checkmark$ & - & Collector efficiency \\
\hline Das \& Kumar, 1989 & $\checkmark$ & $\checkmark$ & $\checkmark$ & $\checkmark$ & $\checkmark$ & - & - & $\checkmark$ & - & \\
\hline Esper et al., 1996 & $\checkmark$ & - & $\checkmark$ & $\checkmark$ & $\checkmark$ & - & $\checkmark$ & - & - & \\
\hline Fuller et al., 1990 & - & $\checkmark$ & $\checkmark$ & $\checkmark$ & $\checkmark$ & - & - & - & - & \\
\hline Fuller, 1995 & $\checkmark$ & $\checkmark$ & $\checkmark$ & $\checkmark$ & - & $\checkmark$ & - & - & - & \\
\hline Gallali et al., 1999 & $\checkmark$ & $\checkmark$ & - & - & $\checkmark$ & - & - & - & - & Sensory evaluation \\
\hline Gnanaranjan et al ., 1997 & $\checkmark$ & $\checkmark$ & $\checkmark$ & $\checkmark$ & $\checkmark$ & $\checkmark$ & $\checkmark$ & - & - & \\
\hline Grupp et al ., 1995 & $\checkmark$ & $\checkmark$ & $\checkmark$ & $\checkmark$ & $\checkmark$ & - & $\checkmark$ & - & $\checkmark$ & Tray area, drying temperature control \\
\hline Janjai et al ., 1998 & $\checkmark$ & $\checkmark$ & - & $\checkmark$ & $\checkmark$ & - & $\checkmark$ & - & - & \\
\hline Mande et al., 1993 & $\checkmark$ & $\checkmark$ & $\checkmark$ & $\checkmark$ & $\checkmark$ & $\checkmark$ & - & $\checkmark$ & - & Thermal efficiency \\
\hline Martinez, 1989 & $\checkmark$ & - & - & $\checkmark$ & - & - & - & - & - & Collector area \\
\hline Mastekbayeva et al ., 1998 & $\checkmark$ & $\checkmark$ & $\checkmark$ & $\checkmark$ & $\checkmark$ & - & $\checkmark$ & - & - & \\
\hline Moyls, 1986 & $\checkmark$ & - & $\checkmark$ & $\checkmark$ & - & - & - & $\checkmark$ & - & \\
\hline Pairintra et al., 1996 & $\checkmark$ & $\checkmark$ & $\checkmark$ & $\checkmark$ & - & $\checkmark$ & $\checkmark$ & - & - & \\
\hline Pengpad \& Rackwichian, 1998 & $\checkmark$ & $\checkmark$ & $\checkmark$ & $\checkmark$ & $\checkmark$ & $\checkmark$ & - & - & $\checkmark$ & Drying efficiency \\
\hline Rahardjo, et al ., 1983 & $\checkmark$ & $\checkmark$ & $\checkmark$ & $\checkmark$ & $\checkmark$ & - & - & - & - & \\
\hline Rakwichian et al ., 1998 & $\checkmark$ & $\checkmark$ & $\checkmark$ & $\checkmark$ & - & $\checkmark$ & - & - & - & $\begin{array}{l}\text { Collector and dryer efficiency, fuel } \\
\text { savings }\end{array}$ \\
\hline Schirmer et al ., 1996 & $\checkmark$ & $\checkmark$ & $\checkmark$ & $\checkmark$ & $\checkmark$ & - & $\checkmark$ & $\checkmark$ & - & \\
\hline Sharma et al ., 1986 & $\checkmark$ & $\checkmark$ & $\checkmark$ & $\checkmark$ & - & $\checkmark$ & - & $\checkmark$ & - & \\
\hline Sharma et al ., 1995 & $\checkmark$ & $\checkmark$ & - & $\checkmark$ & $\checkmark$ & - & $\checkmark$ & $\checkmark$ & - & \\
\hline Sithipong et al., 1985 & $\checkmark$ & - & - & $\checkmark$ & - & $\checkmark$ & - & - & - & \\
\hline Soponronnarit \& Assayo, 1991 & $\checkmark$ & $\checkmark$ & $\checkmark$ & $\checkmark$ & $\checkmark$ & $\checkmark$ & $\checkmark$ & - & - & Drying system efficiency \\
\hline Soponronnarit et al., 1991 & $\checkmark$ & $\checkmark$ & $\checkmark$ & $\checkmark$ & $\checkmark$ & $\checkmark$ & $\checkmark$ & - & - & Specific energy consumption \\
\hline
\end{tabular}

Source: (Leon et al. 2002) 


\section{Appendix 7: Batch size of beef drying}

Generally in Bhutan, longer lengths of the strips are preferred. The width and thickness of the strips are approximately 1 and $3 \mathrm{~cm}$ respectively. However FAO (1990) recommended a strip length of $20-70 \mathrm{~cm}$ for effective drying. Thus the length of the beef strips is assumed as $60 \mathrm{~cm}$, equal to the depth of the dryer trough. The total quantity of beef that could be dried per batch is calculated in the following paragraphs.

$$
\text { Volume of each strip }=0.6 \times 0.01 \times 0.03=0.00018 \mathrm{~m}^{3}
$$

Assuming the gap between strips as $1 \mathrm{~cm}$ for air flow and to avoid contact with each other which otherwise would result in non-uniform drying of the surface in contact with the other strip.

No. of strips in row $=\frac{\text { length of dryer cabinet }}{(\text { width of beef strip }+ \text { gap between strips })}=\frac{2.2}{(0.03+0.01)}=55$

Also, there has to be gap between the rows of beef for loading and unloading of beef strips and to avoid contact with each other. The gap between rows is assumed as 10 $\mathrm{cm}$.

$$
\begin{aligned}
& \text { No. of rows }=\frac{\text { width of dryer cabinet }}{\text { gap between rows }}=\frac{1.25}{0.1}=12 \\
& \begin{aligned}
\text { Total volume of beef per batch }=0.00018 \times 55 \times 12=0.1188 \mathrm{~m}^{3} \\
\text { Quantity of beef per batch }=\text { total volume per batch } \times \text { density of beef } \\
=0.1188 \times 1000=119 \mathrm{~kg}
\end{aligned}
\end{aligned}
$$

Thus the quantity of beef that could be dried per batch is approximately $119 \mathrm{~kg}$. However, the batch size has to be verified as to whether the same air flow rate i.e. $3120 \mathrm{~kg} / \mathrm{hr}$ used for chilli can remove the moisture from beef within the stipulated time.

As suggested by Fuller and Lu Aye (2002), this can be done by making two assumptions. The first assumption is the average pick-up efficiency through the drying period, which according to Brenndorfer et al. (1985 in Fuller \& Lu Aye 2002) is 
approximately $30 \%$ for a well designed dryer system. The second assumption is dryer exhaust air relative humidity which is assumed as $40 \%$ as suggested by Dahlenburg (1975 in Fuller \& Lu Aye 2002). Using these two assumptions and referring to the psychrometric chart in Fig. A.1, the quantity of moisture that can be removed by the drying air at $60^{\circ} \mathrm{C}$ and $3120 \mathrm{~kg} / \mathrm{hr}$ is calculated as shown below.

$$
\begin{aligned}
\text { Relative humidity of ambinet air } & =70 \% \\
\text { Average ambient air temp. } & =15^{\circ} \mathrm{C} \\
\text { Humidity ratio of ambient air, } W_{i} & =7 \mathrm{gm} / \mathrm{kg} \\
\text { Humidity ratio of exhaust drying air, } W_{o} & =18 \mathrm{gm} / \mathrm{kg} \quad \text { (from psychrometric chart) } \\
\left(\begin{array}{c}
\text { Moisture removal capacity } \\
\text { of drying air per hour }
\end{array}\right) & =\left(\frac{W_{o}-W_{i}}{1000}\right) \times \text { air flow rate } \times \text { pick }- \text { up efficiency } \\
& =\left(\frac{18-7}{1000}\right) \times 3120 \times 0.3=10.3 \mathrm{~kg} / \mathrm{hr}
\end{aligned}
$$

Assuming drying time of beef as 8 hours from Section 3.4.2,

$$
\begin{aligned}
\left(\begin{array}{l}
\text { Moisture } \\
\text { evaporated } \\
\text { per hour }
\end{array}\right) & =\frac{\left(\begin{array}{l}
\text { Weight of } \\
\text { wet sample }
\end{array}\right) \times\left[\left(\begin{array}{l}
\text { Initial moisture } \\
\text { content of product }
\end{array}\right)-\left(\begin{array}{l}
\text { Final moisture content } \\
\text { of product }
\end{array}\right)\right]}{(100-\text { Final moisture content of product }) \times \text { Duration of drying time }} \\
& =\frac{119 \times(80-10)}{(100-10) \times 8}=11.6 \mathrm{~kg} / \mathrm{hr}
\end{aligned}
$$

However, the design air flow rate of $3120 \mathrm{~kg} / \mathrm{hr}$ can remove only $10.3 \mathrm{~kg}$ of moisture per hour. This is less than the moisture evaporation rate of the above batch size. Therefore, the batch size has to be reduced to $100 \mathrm{~kg}$. At this batch size, the moisture evaporation rate is $9.7 \mathrm{~kg} / \mathrm{hr}$ which is less than the moisture removal capacity of the dryer air flow rate. Hence the batch size for beef is fixed at $100 \mathrm{~kg} / \mathrm{batch}$. 


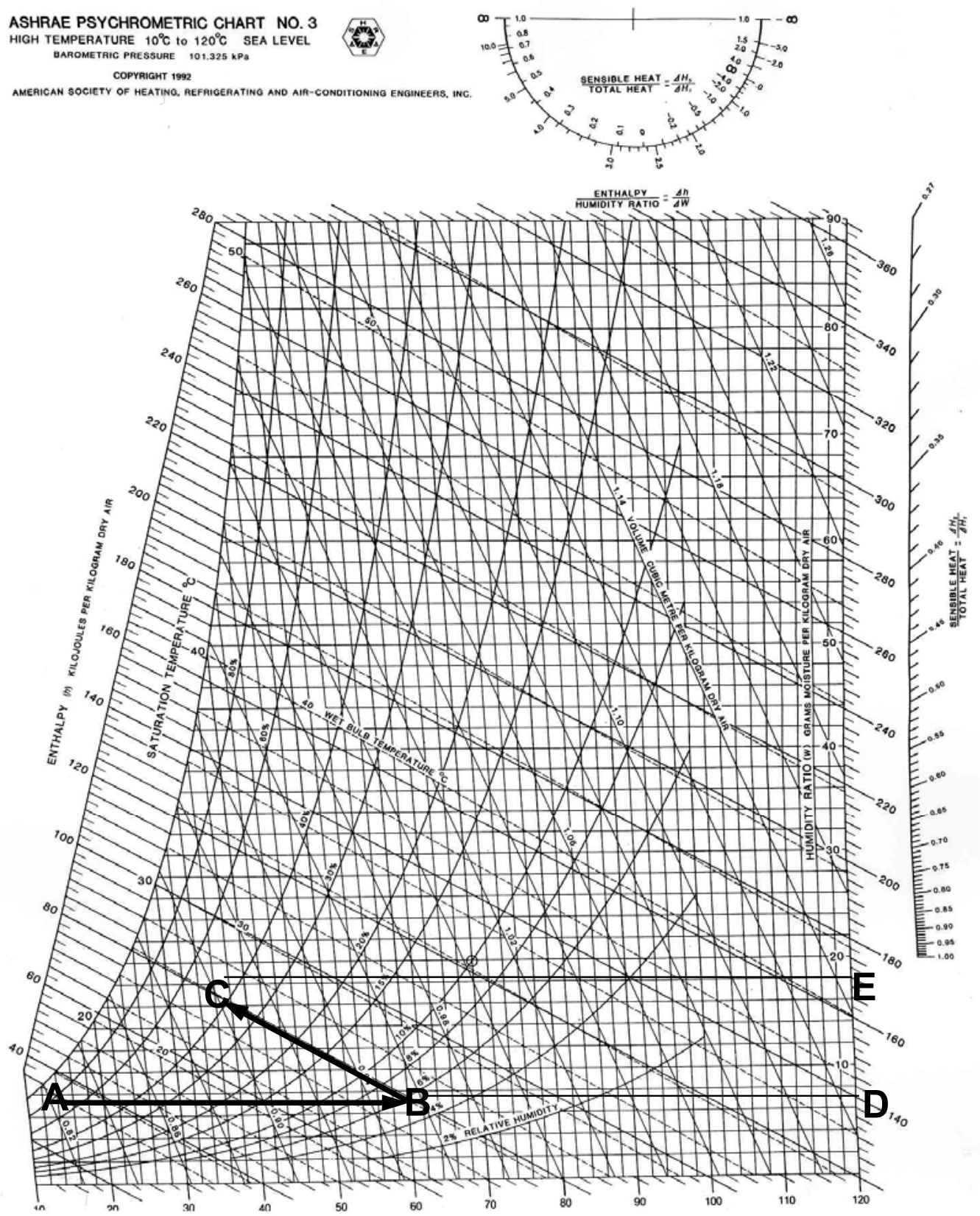

Fig. A.1. Psychromteirc chart

Source: (ASHRAE 2001)

The humidity ratio of ambient air is $7 \mathrm{gm} / \mathrm{kg}$ of dry air (pint D) while it is $18 \mathrm{gm} / \mathrm{kg}$ of dry air (pint E) for air outlet from the dryer. 


\section{Appendix 8: TRNSYS components}

The TRNSYS components used in this study are briefly explained in the following sections. The individual TRNSYS components are connected and they form a flowchart of information from one component to another. Fig. A.2 shows the information flow diagram. The information flow diagram shows the manner in which all the system components are interconnected. The arrow heads show the direction of flow of information.

\section{i. Weather data generator: Type 54}

As explained in Section 4.2, this component generates hourly weather data with average monthly solar radiation, dry bulb temperature, humidity ratio and wind speed as inputs. The data file generated is similar to a Typical Meteorological Year data file.

\section{ii. Solar radiation processor: Type 16}

As the weather generator generates horizontal surface radiation over an hourly interval, the solar radiation processor is used to calculate the solar radiation at a different orientation, i.e. that of the collector. This subroutine also can interpolate the data over different time intervals if required.

\section{iii. Solar collector: Type 1}

The thermal performance of the flat plate solar collector is modeled using a Type 1 solar collector. This subroutine converts the solar radiation falling on the absorber plate into heat by taking into account the mass flow rate, specific heat and the inlet temperature of air. Also this subroutine computes the temperature rise of the air flowing through the collector and the total energy gained by the collector.

\section{iv. Fan: Type 3}

Since the dryer in this study is a forced convective type, a fan is used to circulate the drying air. The fan requires an external energy source i.e. electricity to drive it. 


\section{v. Auxiliary heaters: Type 6}

As the dryer in this study is intended to be used during different times of the year and day, a supplementary energy source is necessary to increase the air temperature during the times of no or low solar radiation. This component computes the total supplementary energy required by the dryer at these times, including the losses.

However, this subroutine does not take into account the energy used for driving fan.

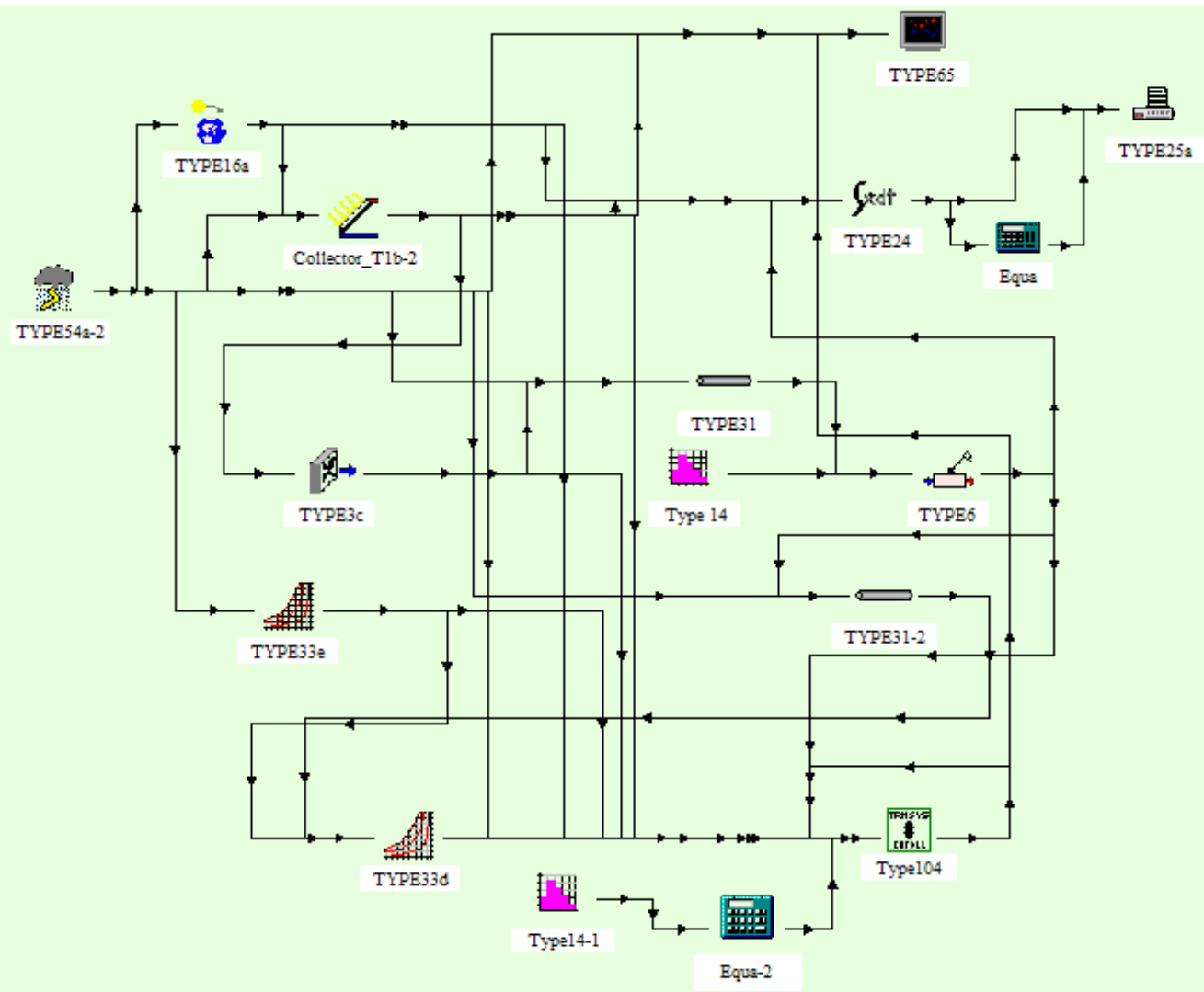

Fig. A.2. Information flow diagram in TRNSYS model

\section{vi. Pipe duct: Type 31-1 and Type 31-2}

This component is used to model the air ducts used in the system. Both the ducts before and after the auxiliary heater are represented by this component. This component calculates the energy losses occurring in the air ducts. 


\section{vii. Forcing function: Type 14-1}

This component is used to control the operation of the auxiliary heater. The instantaneous output of this component is connected as a control signal of the auxiliary heater. This component will only turn the auxiliary heater on when the dryer is loaded and there is either low or no solar radiation.

\section{viii. Forcing function-1: Type 14-2 in conjunction with Equa-2}

These two components are used to model the operating cycle of the dryer. For example, during the months of August and September, these two components will simulate starting the dryer at 10 a.m and turning the dryer off at set time. This loading cycle will be repeated everyday during the months of August and September. The outputs of the equation are connected as inputs to the dryer.

\section{ix. Psychrometrics: Type 33 d \& e}

Two psychrometric subroutines are used to compute the parameters such as wet bulb temperature, relative humidity and specific humidity of the drying air. These parameters are used as inputs to the dryer.

\section{x. Quantity integrator: Type 24 in conjunction with Equa-1}

These components are used to compute the total useful energy gain by the solar collector, total auxiliary energy required and solar fraction of the drying system. The solar fraction is calculated using Equation A.1 (Duffie \& Beckman 1991)

$$
S F=\frac{Q_{s i}}{Q_{s i}+Q_{a i}}
$$

where $S F=$ solar fraction

$Q_{a i}=$ energy required by auxiliary heater $(\mathrm{kJ})$

$Q_{s i}=$ energy gained by solar energy $\operatorname{system}(\mathrm{kJ})$ 


\section{Appendix 9: Source code for Type 104 TRNSYS component}

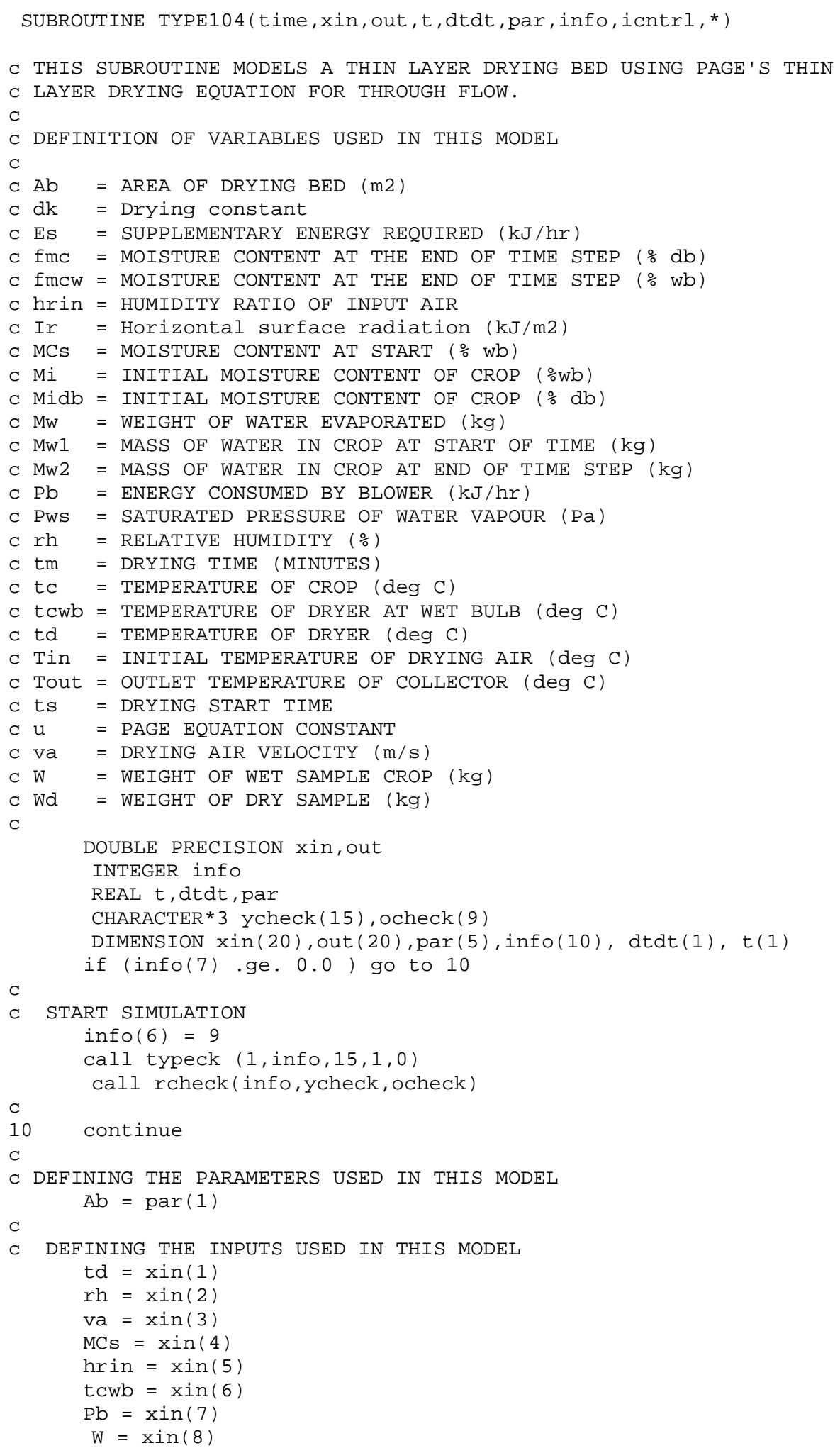




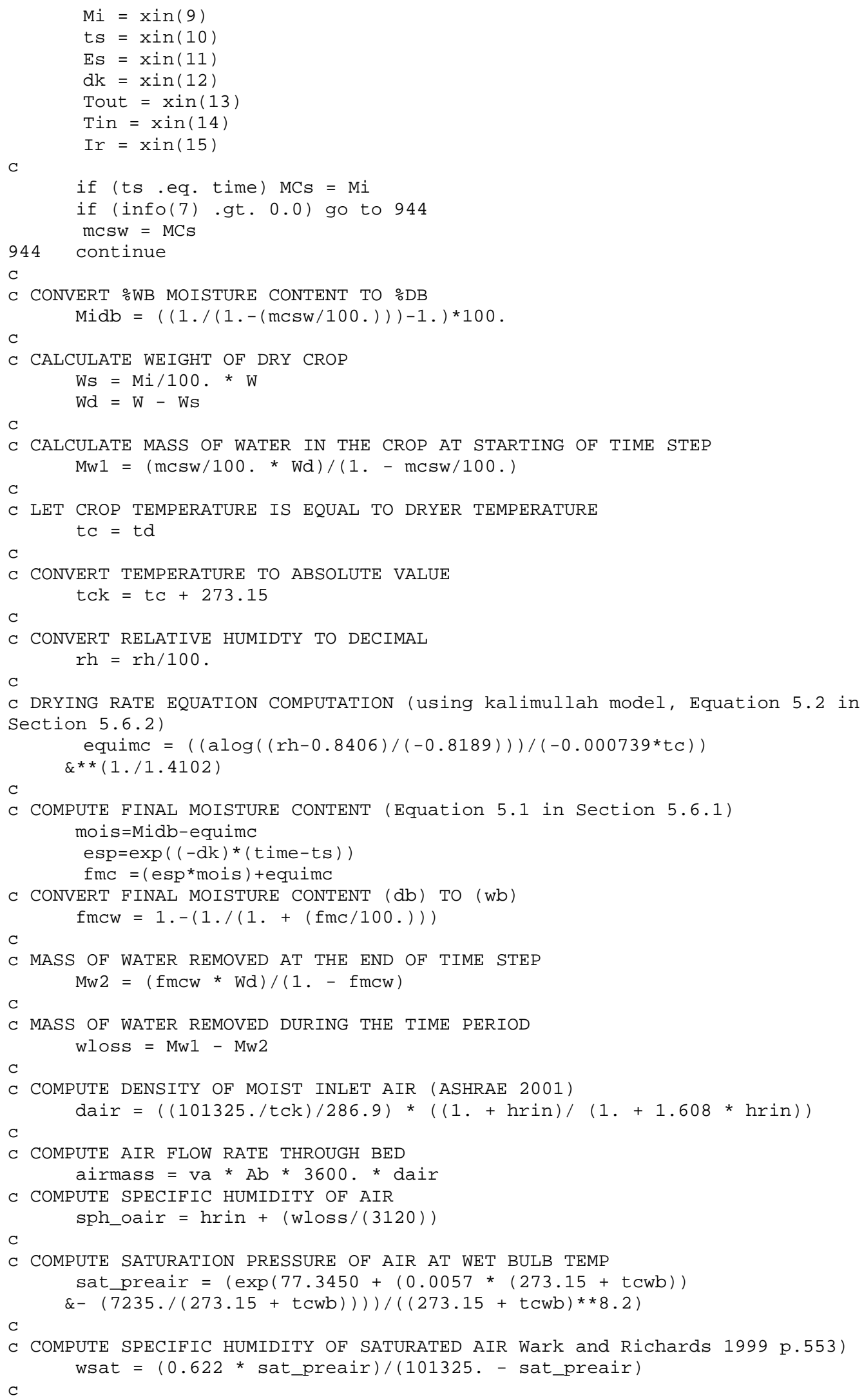




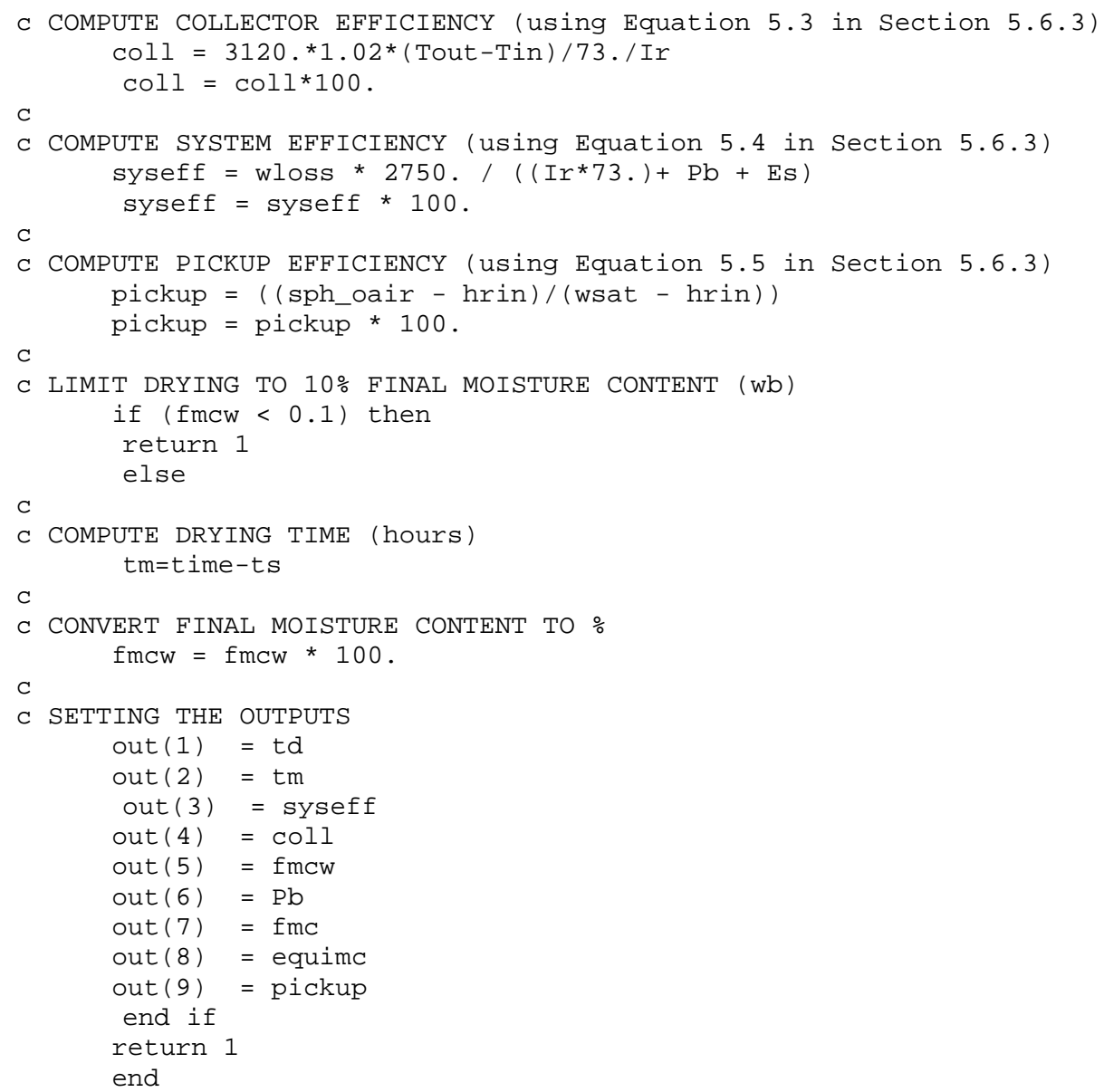




\section{Appendix 10: Estimation of real discount rate}

The discount rate is a factor by which the future sum of money is converted to present value. This is of two different rates. The first one is nominal discount rate, which does not take into account the inflation rate of a country. The other is real discount rate which takes into account the inflation rate of a country. The real discount rate can be calculated by the Equation A.2.

$\begin{array}{rll}i_{r} & = & \frac{\left(i_{\text {nominal }}-i\right)}{(1+i)} \\ \text { Where, ir } & = & \text { real discount rate } \\ i_{\text {nominal }} & = & \text { nominal discount rate } \\ i & = & \text { inflation rate }\end{array}$

The inflation rate of a country is the change in the price over a certain time period. The inflation rate is calculated from the consumer price index of a country over the given period of a time by the Equation A.3 (Taggart et al. 1996 p.520).

Inflation rate $=\frac{(\text { Current year's price level }- \text { Last year's price level })}{(\text { Last year's price level })} \times 100$

The inflation rate for nine years based on the consumer price index was calculated. The inflation rate was then used to calculate the real discount rate of Bhutan. Further, a $13 \%$ interest rate was used based on the present lending rate of the banks in Bhutan. From Table 1, Bhutan's real discount rate varies from $6 \%$ to $13 \%$. So, in this study a real discount rate of $13 \%$ was adopted based on year 2004 . 
Table A.1: Consumer price index and real discount rate

\begin{tabular}{|c|c|c|c|c|}
\hline Year & Month & $\begin{array}{l}\text { Consumer price } \\
\text { index }(\%)\end{array}$ & $\begin{array}{c}\text { Half-yearly } \\
\text { inflation (\%) }\end{array}$ & $\begin{array}{l}\text { Real discount } \\
\text { rate }(\%)\end{array}$ \\
\hline \multirow{2}{*}{1995} & June & 413.2 & - & - \\
\hline & Dec & 437.7 & 5.93 & 6.67 \\
\hline \multirow{2}{*}{1996} & June & 451.7 & 3.20 & 9.50 \\
\hline & Dec & 474.1 & 4.96 & 7.66 \\
\hline \multirow{2}{*}{1997} & June & 484.9 & 2.28 & 10.48 \\
\hline & Dec & 501.2 & 3.36 & 9.33 \\
\hline \multirow{2}{*}{1998} & June & 528.7 & 5.49 & 7.12 \\
\hline & Dec & 561.7 & 6.24 & 6.36 \\
\hline \multirow{2}{*}{1999} & June & 577.3 & 2.78 & 9.95 \\
\hline & Dec & 587.0 & 1.68 & 11.13 \\
\hline \multirow{2}{*}{2000} & June & 598.1 & 1.89 & 10.90 \\
\hline & Dec & 612.9 & 2.47 & 10.27 \\
\hline \multirow{2}{*}{2001} & June & 619.5 & 1.08 & 11.80 \\
\hline & Dec & 632.8 & 2.15 & 10.63 \\
\hline \multirow{2}{*}{2002} & June & 636.1 & 0.52 & 12.41 \\
\hline & Dec & 647.2 & 1.75 & 11.06 \\
\hline \multirow{2}{*}{2003} & June & 647.8 & 0.09 & 12.90 \\
\hline & Dec & 655.7 & 1.22 & 11.64 \\
\hline 2004 & June & 655.9 & 0.03 & 12.97 \\
\hline
\end{tabular}

* Based on 1979 base year, i.e December $1979=100 \%$

Nominal interest rate: $13 \%$

Source: (RMA 2001, 2003, 2004) 


\section{Appendix 11: Detailed cost estimate of the solar dryer system}

\begin{tabular}{|c|c|c|c|c|c|c|c|}
\hline & Particulars & Unit & Rate (Nu) & Qty. & Amount (Nu) & $\begin{array}{c}\text { Amount } \\
\text { (US \$) }\end{array}$ & $\begin{array}{l}\text { Percentage } \\
\text { of total cost }\end{array}$ \\
\hline \multirow[t]{4}{*}{1} & Land clearing & & & & & & \\
\hline & $\begin{array}{l}\text { Clearing jungle including uprooting of } \\
\text { vegetation }\end{array}$ & $\mathrm{m}^{2}$ & 4.21 & 100.00 & 421.00 & 9.27 & 0.40 \\
\hline & $\begin{array}{l}\text { Providing and laying cement, concrete } 1: 5: 10 \text {; } \\
50 \mathrm{~mm} \text { aggregates in plinth }\end{array}$ & $\mathrm{m}^{3}$ & 1490.00 & 3.65 & 5438.50 & 119.79 & 5.11 \\
\hline & Sub total & & & & 6738.43 & 148.42 & 6.34 \\
\hline \multirow[t]{9}{*}{2} & Solar collector and accessories & & & & & & \\
\hline & CGI sheet, $24 \mathrm{~g}(0.63 \mathrm{~mm})$ & tonne & 32038.00 & 0.36 & 11565.72 & 254.75 & 10.87 \\
\hline & Timber, mixed conifer & $\mathrm{m}^{3}$ & 2825.00 & 1.20 & 3390.00 & 74.67 & 3.19 \\
\hline & Plywood, $4 \mathrm{~mm}$ thick, commercial ply & $\mathrm{m}^{2}$ & 97.00 & 73.00 & 7081.00 & 155.97 & 6.66 \\
\hline & Plain glass, $3 \mathrm{~mm}$ thick & $\mathrm{m}^{2}$ & 210.00 & 73.00 & 15330.00 & 337.67 & 14.41 \\
\hline & Black paint & litre & 82.00 & 20.00 & 1640.00 & 36.12 & 1.54 \\
\hline & Putty (for sealing gaps) & $\mathrm{kg}$ & 20.00 & 20.00 & 400.00 & 8.81 & 0.38 \\
\hline & Saw dust & $\mathrm{kg}$ & 1.00 & 1600.00 & 1600.00 & 35.24 & 1.50 \\
\hline & Sub total & & & & 47157.73 & 1038.72 & 44.33 \\
\hline \multirow[t]{5}{*}{3} & Dryer trough and frame & & & & & & \\
\hline & Steel sheet (250 Mpa), $3.5 \mathrm{~mm}$ thick & $\mathrm{kg}$ & 24.00 & 157.00 & 3768.00 & 83.00 & 3.54 \\
\hline & Timber, mixed conifer & $\mathrm{m}^{3}$ & 2825.00 & 0.50 & 1412.50 & 31.11 & 1.33 \\
\hline & Wire gauze, $0.85 \mathrm{~mm}$ aperture & $\mathrm{m}^{2}$ & 86.20 & 3.00 & 258.60 & 5.70 & 0.24 \\
\hline & Sub total & & & & 6254.97 & $\mathbf{1 3 7 . 7 7}$ & 5.88 \\
\hline
\end{tabular}




\begin{tabular}{|c|c|c|c|c|c|c|c|}
\hline & Particulars & Unit & Rate (Nu) & Qty. & Amount (Nu) & $\begin{array}{c}\text { Amount } \\
\text { (US \$) }\end{array}$ & $\begin{array}{l}\text { Percentage } \\
\text { of total cost }\end{array}$ \\
\hline \multirow[t]{5}{*}{4} & Duct heater, blower and ducts & & & & & & \\
\hline & Duct heater & No & 21562.50 & 1.00 & 21562.50 & 474.94 & 20.27 \\
\hline & Blower, $2 \mathrm{~kW}, 220 \mathrm{~V}, 10 \mathrm{~A}, 50 \mathrm{~Hz}$ & No & 14400.00 & 1.00 & 14400.00 & 317.18 & 13.54 \\
\hline & Plain GI sheet, 24g (for ducts) & tonne & 32560.00 & 0.03 & 1123.32 & 24.74 & 1.06 \\
\hline & Sub total & & & & 37085.82 & 816.87 & 34.87 \\
\hline \multirow[t]{3}{*}{5} & Miscellaneous items & & & & & & \\
\hline & Nails, bolts, nuts and screws & $\mathrm{kg}$ & 32.00 & 2.00 & 64.00 & 1.41 & 0.06 \\
\hline & Sub total & & & & 73.60 & 1.62 & 0.07 \\
\hline \multirow[t]{2}{*}{6} & Installation and labour cost ( $10 \%$ of sum of $2-5)$ & & & & 9057.21 & 199.50 & 8.51 \\
\hline & Subtotal & & & & 9057.21 & 199.50 & 8.51 \\
\hline 7 & Grand total & & & & 106367.75 & 2342.90 & \\
\hline
\end{tabular}


Appendix 12: Exchange rate, US Dollar to Ngultrum

\begin{tabular}{lcccccc}
\hline \multicolumn{1}{c}{ Period } & $\mathbf{1 9 9 9}$ & $\mathbf{2 0 0 0}$ & $\mathbf{2 0 0 1}$ & $\mathbf{2 0 0 2}$ & $\mathbf{2 0 0 3}$ & $\mathbf{2 0 0 4}$ \\
\hline Jannuary & 42.51 & 43.55 & 46.54 & 48.34 & 47.93 & 45.46 \\
February & 42.46 & 43.61 & 46.52 & 48.69 & 47.74 & 45.27 \\
March & 42.44 & 43.59 & 46.62 & 48.74 & 47.65 & 45.02 \\
April & 42.73 & 43.64 & 46.79 & 48.92 & 47.38 & 43.93 \\
May & 42.77 & 43.97 & 46.98 & 49.00 & 47.08 & 45.25 \\
June & 43.14 & 44.69 & 47.01 & 48.96 & 46.72 & 45.51 \\
July & 43.29 & 44.78 & 47.13 & 48.76 & 46.23 & - \\
August & 43.46 & 45.69 & 47.13 & 48.59 & 45.94 & - \\
September & 43.54 & 45.89 & 47.65 & 48.44 & 45.85 & - \\
October & 43.45 & 46.35 & 48.02 & 48.37 & 45.39 & - \\
November & 43.40 & 46.78 & 48.00 & 48.38 & 45.47 & - \\
December & 43.30 & 46.75 & 47.92 & 48.14 & 45.59 & - \\
Average & 43.04 & 44.94 & 47.13 & 48.61 & 46.58 & 45.07 \\
\hline
\end{tabular}

Source: (RMA 2004) 


\section{Appendix 13: Cost-benefit analysis of chilli only}

\begin{tabular}{|c|c|c|c|}
\hline & Parameters & Unit & Amount (US \$) \\
\hline \multirow[t]{4}{*}{1} & Parameters & & \\
\hline & Capacity of dryer to dry chilli & tonne/year & 4.50 \\
\hline & Price of fresh chilli ${ }^{\text {a }}$ & US $\$ / \mathrm{kg}$ & 0.98 \\
\hline & Price of dried chilli ${ }^{b}$ & US $\$ / \mathrm{kg}$ & 4.91 \\
\hline \multirow[t]{2}{*}{2} & Capital cost & & \\
\hline & Total investment cost & US \$ & 2342.90 \\
\hline \multirow[t]{5}{*}{3} & Operating cost & & \\
\hline & Total supplementary energy cost & US \$/year & 453.44 \\
\hline & Operators salary & US \$/year & 86.96 \\
\hline & Cost of fresh chilli & US \$/year & 4402.17 \\
\hline & Sub total & & 4942.57 \\
\hline \multirow[t]{2}{*}{4} & Benefits & & \\
\hline & Revenue from sale of dried chilli & US \$/year & 3682.26 \\
\hline \multirow[t]{13}{*}{5} & Discounted cash flow analysis & & \\
\hline & Residual value & US \$ & 468.58 \\
\hline & Discount rate & decimal & 0.13 \\
\hline & Project life & years & 15.00 \\
\hline & Discounted revenue & US \$ & 23796.15 \\
\hline & Discounted residual value & US \$ & 74.92 \\
\hline & Discounted O \& M cost & US \$ & 31940.76 \\
\hline & Total discounted benefit & US \$ & 23871.07 \\
\hline & Total discounted costs & US \$ & 34283.66 \\
\hline & Net present value & US \$ & -10412.60 \\
\hline & Benefit cost ratio & & 0.70 \\
\hline & Internal rate of return & $\%$ & - \\
\hline & Discounted pay backperiod & year & - \\
\hline
\end{tabular}

Source: ${ }^{a}$ - (MoA 2004b)

b - (MoA 2004a) 


\section{Appendix 14: Cost-benefit analysis of chilli \& beef combined}

\begin{tabular}{|c|c|c|c|}
\hline & Parameters & Unit & Amount (US \$) \\
\hline \multirow[t]{7}{*}{1} & Parameters & & \\
\hline & Capacity of dryer to dry chilli & tonne/year & 4.50 \\
\hline & Capacity of dryer to dry beef & tonne/year & 24.40 \\
\hline & Price of fresh chilli & US $\$ / \mathrm{kg}$ & 0.98 \\
\hline & Price of dried chilli & US $\$ / k g$ & 4.91 \\
\hline & Price of fresh beef ${ }^{c}$ & US $\$ / \mathrm{kg}$ & 1.14 \\
\hline & Price of dried beef ${ }^{\mathrm{d}}$ & US $\$ / k g$ & 5.43 \\
\hline \multirow[t]{2}{*}{2} & Capital cost & & \\
\hline & Total investment cost & US $\$$ & 2342.90 \\
\hline \multirow[t]{6}{*}{3} & Operating cost & & \\
\hline & Total supplementary energy cost & US \$/year & 2205.64 \\
\hline & Operators salary & US \$/year & 521.74 \\
\hline & Cost of fresh chilli & US \$/year & 4402.17 \\
\hline & Cost of fresh beef & US \$/year & 27847.83 \\
\hline & Sub total & & 34977.38 \\
\hline \multirow[t]{3}{*}{4} & Benefits & & \\
\hline & Revenue from sale of dried chilli & US \$/year & 3682.26 \\
\hline & Revenue from sale of dried beef & US \$/year & 29439.13 \\
\hline \multirow[t]{13}{*}{5} & Discounted cash flow analysis & & \\
\hline & Residual value & US $\$$ & 468.58 \\
\hline & Discount rate & decimal & 0.13 \\
\hline & Project life & years & 15.00 \\
\hline & Discounted revenue & US $\$$ & 214042.96 \\
\hline & Discounted residual value & US \$ & 74.92 \\
\hline & Discounted $O \& M$ cost & US $\$$ & 226037.07 \\
\hline & Total discounted benefit & US \$ & 214117.88 \\
\hline & Total discounted costs & US \$ & 228379.98 \\
\hline & Net present value & US $\$$ & -14262.09 \\
\hline & Benefit cost ratio & & 0.94 \\
\hline & Internal rate of return & $\%$ & - \\
\hline & Discounted pay backperiod & year & - \\
\hline
\end{tabular}

Source: ${ }^{c}-($ MoA 2004b)

d - (Wangmo 2004) 
Appendix 15: Optimisation of collector area

\begin{tabular}{|c|c|c|c|c|c|c|c|}
\hline \multirow{2}{*}{$\begin{array}{l}\text { Area } \\
\left(\mathbf{m}^{2}\right)\end{array}$} & \multirow{2}{*}{$\begin{array}{l}\text { Fixed cost } \\
\text { (US\$) }\end{array}$} & \multirow{2}{*}{$\begin{array}{c}\text { Variable } \\
\text { cost (US \$) }\end{array}$} & \multirow{2}{*}{$\begin{array}{c}\text { Maintenance } \\
\text { cost (US \$) }\end{array}$} & \multirow{2}{*}{$\begin{array}{c}\text { Salvage value } \\
\text { (US \$) }\end{array}$} & \multicolumn{2}{|c|}{ Supplementary energy cost } & \multirow{2}{*}{$\begin{array}{c}\text { Total annual cost } \\
\text { (US \$) }\end{array}$} \\
\hline & & & & & chilli (US \$) & Beef (US \$) & \\
\hline 0 & 1174.34 & 0.00 & 27.54 & 112.70 & 588.86 & 2145.67 & 2894.07 \\
\hline 10 & 1174.34 & 161.60 & 31.33 & 128.21 & 564.42 & 2057.40 & 2803.32 \\
\hline 20 & 1174.34 & 323.20 & 35.12 & 143.72 & 540.36 & 1988.14 & 2731.95 \\
\hline 30 & 1174.34 & 484.81 & 38.91 & 159.23 & 519.18 & 1943.47 & 2688.06 \\
\hline 40 & 1174.34 & 646.41 & 42.70 & 174.74 & 500.23 & 1893.03 & 2640.62 \\
\hline 50 & 1174.34 & 808.01 & 46.49 & 190.25 & 484.12 & 1844.55 & 2597.98 \\
\hline 60 & 1174.34 & 969.61 & 50.28 & 205.76 & 469.67 & 1800.60 & 2561.54 \\
\hline 70 & 1174.34 & 1131.21 & 54.07 & 221.27 & 456.95 & 1762.20 & 2532.37 \\
\hline 80 & 1174.34 & 1292.82 & 57.86 & 236.77 & 445.76 & 1727.56 & 2508.50 \\
\hline 90 & 1174.34 & 1454.42 & 61.65 & 252.28 & 435.90 & 1694.44 & 2487.47 \\
\hline 100 & 1174.34 & 1616.02 & 65.44 & 267.79 & 427.22 & 1664.45 & 2470.76 \\
\hline 110 & 1174.34 & 1777.62 & 69.23 & 283.30 & 419.59 & 1638.04 & 2458.67 \\
\hline 120 & 1174.34 & 1939.22 & 73.02 & 298.81 & 412.86 & 1615.72 & 2451.58 \\
\hline 130 & 1174.34 & 2100.82 & 76.81 & 314.32 & 406.94 & 1595.25 & 2447.14 \\
\hline 140 & 1174.34 & 2262.43 & 80.60 & 329.83 & 401.73 & 1577.23 & 2445.87 \\
\hline 150 & 1174.34 & 2424.03 & 84.39 & 345.34 & 397.17 & 1561.36 & 2447.39 \\
\hline 160 & 1174.34 & 2585.63 & 88.18 & 360.85 & 393.17 & 1547.39 & 2451.38 \\
\hline 170 & 1174.34 & 2747.23 & 91.97 & 376.36 & 389.65 & 1535.12 & 2457.54 \\
\hline 180 & 1174.34 & 2908.83 & 95.76 & 391.86 & 386.55 & 1524.29 & 2465.56 \\
\hline 190 & 1174.34 & 3070.44 & 99.55 & 407.37 & 383.85 & 1514.76 & 2475.29 \\
\hline 200 & 1174.34 & 3232.04 & 103.34 & 422.88 & 381.47 & 1506.38 & 2486.48 \\
\hline
\end{tabular}




\section{Appendix 16: Cost-benefit analysis of optimised system}

\begin{tabular}{|c|c|c|c|c|}
\hline & \multirow[b]{2}{*}{ Parameters } & \multirow[b]{2}{*}{ Unit } & \multicolumn{2}{|c|}{ Amount (US \$) } \\
\hline & & & Solar system & $\begin{array}{c}\text { Electrical heating } \\
\text { system }\end{array}$ \\
\hline \multirow[t]{7}{*}{1} & Parameters & & & \\
\hline & Capacity of dryer to dry chilli & tonne/year & 4.50 & 4.50 \\
\hline & Capacity of dryer to dry beef & tonne/year & 24.40 & 24.40 \\
\hline & Price of fresh chilli & US $\$ / \mathrm{kg}$ & 0.98 & 0.98 \\
\hline & Price of dried chilli & US $\$ / \mathrm{kg}$ & 4.91 & 4.91 \\
\hline & Price of fresh beef & US $\$ / \mathrm{kg}$ & 1.14 & 1.14 \\
\hline & Price of dried beef & US $\$ / \mathrm{kg}$ & 5.43 & 5.43 \\
\hline \multirow[t]{2}{*}{2} & Capital cost & & & \\
\hline & Total investment cost & US \$ & 3436.77 & 1174.34 \\
\hline \multirow[t]{6}{*}{3} & Operating cost & & & \\
\hline & Total supplementary energy cost & US \$/year & 1978.96 & 2734.53 \\
\hline & Operators salary & US \$/year & 521.74 & 521.74 \\
\hline & Cost of fresh chilli & US \$/year & 4402.17 & 4402.17 \\
\hline & Cost of fresh beef & US \$/year & 27847.83 & 27847.83 \\
\hline & Sub total & & 34750.70 & 35506.27 \\
\hline \multirow[t]{3}{*}{4} & Benefits & & & \\
\hline & Revenue from sale of dried chilli & US \$/year & 3682.26 & 3682.26 \\
\hline & Revenue from sale of dried beef & US \$/year & 29439.13 & 29439.13 \\
\hline \multirow[t]{13}{*}{5} & Discounted cash flow analysis & & & \\
\hline & Residual value & US \$ & 687.35 & 234.87 \\
\hline & Discount rate & decimal & 0.13 & 0.13 \\
\hline & Project life & years & 15.00 & 15.00 \\
\hline & Discounted revenue & US \$ & 214042.96 & 214042.96 \\
\hline & Discounted residual value & US \$ & 109.90 & 37.55 \\
\hline & Discounted O \& M cost & US \$ & 224572.18 & 229454.96 \\
\hline & Total discounted benefit & US \$ & 214152.86 & 214080.51 \\
\hline & Total discounted costs & US \$ & 228008.95 & 230629.30 \\
\hline & Net present value & US \$ & -13856.09 & -16548.79 \\
\hline & Benefit cost ratio & & 0.94 & 0.93 \\
\hline & Internal rate of return & $\%$ & - & - \\
\hline & Discounted pay backperiod & year & - & - \\
\hline
\end{tabular}




\section{APPENDIX 17: Source code of Type 104 TRNSYS component in $C D$}

\section{References}

ASHRAE 2001, ASHRAE Handbook: Fundamentals, SI edition, American Society for Heating, Refrigeration and Air Conditioning Engineers, Tulliecircle, Atlanta, USA.

Audsley, E and Wheeler, J 1978, 'The annual cost of machinery calculated using actual cash flows', Journal of Agricultural Engineering Research, vol. 23, no. 2, pp. 189-201.

CSO 2003, Statistical Yearbook of Bhutan, The Planning Commission Secretariat, Royal Government of Bhutan, Thimphu, Bhutan.

Duffie, JA and Beckman, WA 1991, Solar Engineering of Thermal Processes, 2nd edn, John Wiley and Sons Inc., Wisconsin-Madison, USA.

FAO 1990, Manual on simple methods of meat preservation, 79, Food and Agriculture Organisation of the United Nations, Rome, Italy.

Fuller, RJ and Lu Aye 2002, 'Design of a Solar Assisted meat dryer', paper presented to Solar Harvest 2002, Newcastle, Australia, 27-30 November 2002.

Hossain, MA, Woods, JL and Bala, BK 2004, 'Optimisation of solar tunnel drier for drying of chilli without color loss', Renewable Energy, vol. In Press, Corrected Proof.

Kreider, JF, Hoogendoorn, CJ and Kreith, F 1989, Solar Design: Components, Systems, Economics, Hemisphere Publishing Corporation, New York, USA. 
Leon, MA, Kumar, S and Bhattacharya, SC 2002, 'A comprehensive procedure for performance evaluation of solar food dryers', Renewable and Sustainable Energy Reviews, vol. 6, no. 4, pp. 367-93.

MoA 2000, Renewable Natural Resources Statistics 2000, Ministry of Agriculture, Thimphu, Bhutan.

MoA 2004a, Average Retail Prices for the Month of January to June, 2003, Agriculture Marketing Service, Ministry of Agriculture, viewed 7 August 2004, $<$ http://www.moa.gov.bt/newsy/ams_prices.htm>.

MoA 2004b, Average retail price for the following markets for the months of (January - June 2004), Agriculture Marketing Service, Ministry of Agriculture, viewed 15 August 2004, <http://www.moa.gov.bt/newsy/ams_prices.htm>.

NASA 2004a, NASA Surface Meteorology and Solar Energy: Global/regional data, $<$ http://eosweb.larc.nasa.gov/cgi-bin/sse/sse.cgi?na+s01\#s01>.

NASA 2004b, NASA Surface Meteorology and Solar Energy: Accuracy, $<$ http://eosweb.larc.nasa.gov/cgi-bin/sse/sse.cgi?na+s05\#s05>.

PCS 2002, Ninth plan report presented to the 80th session of the National Assembly, June 2002, The Planning Commission Secretariat, Royal Government of Bhutan, Thimphu, Bhutan, viewed 7 February 2004, $<$ http://www.pcs.gov.bt/rep/9pr80na.pdf $>$.

RMA 2001, Selected Economic Indicators, Royal Monetary Authority of Bhutan, Thimphu, Bhutan.

RMA 2003, Selected Economic Indicators, 4, Royal Monetary Authority of Bhutan, Thimphu, Bhutan. 
RMA 2004, Selected Economic Indicators, 2, Royal Monetary Authority of Bhutan, Thimphu, Bhutan.

Simate, IN 2003, 'Optimization of mixed-mode and indirect-mode natural convection solar dryers', Renewable Energy, vol. 28, no. 3, pp. 435-53.

Taggart, DM, Findley, C and Parkin, M 1996, Economics, 2 edn, Addison-Wesley Publishing Company, Melbourne, Australia.

Unimelb 1980, Theory and Design of Solar Thermal Systems, Mechanical Engineering Department, The University of Melbourne, Melbourne, Australia.

Wangmo, D 2004, Personal communication, Assistant Agriculture Extension Agent, Phuentsholing, Bhutan.

Yuden, P 2000, 'Effects of pruning on yield, quality and costs of mandarin orange production in Bhutan', Master of Applied Science (Horticulture) thesis, The University of Melbourne. 


\section{University Library}

\section{- M I I N E R VA \\ A gateway to Melbourne's research publications}

Minerva Access is the Institutional Repository of The University of Melbourne

Author/s:

LHENDUP, TSHEWANG

Title:

Technical and financial feasibility of a solar dryer in Bhutan

Date:

2005

Persistent Link:

http://hdl.handle.net/11343/191345

Terms and Conditions:

Terms and Conditions: Copyright in works deposited in Minerva Access is retained by the copyright owner. The work may not be altered without permission from the copyright owner. Readers may only download, print and save electronic copies of whole works for their own personal non-commercial use. Any use that exceeds these limits requires permission from the copyright owner. Attribution is essential when quoting or paraphrasing from these works. 